UNIVERSIDADE DE SÃO PAULO
FACULDADE DE ODONTOLOGIA DE RIBEIRÃO PRETO

PAULA REGINA ÁVILA SILVANO

EFEITO DO LASER DE BAIXA POTÊNCIA NA VASCULARIZAÇÃO DA SUTURA PALATINA MEDIANA, APÓS A EXPANSÃO RÁPIDA DA MAXILA, EM RATOS WISTAR 



\title{
EFEITO DO LASER DE BAIXA POTÊNCIA NA VASCULARIZAÇÃO DA SUTURA PALATINA MEDIANA, APÓS A EXPANSÃO RÁPIDA DA MAXILA, EM RATOS WISTAR
}

\author{
Dissertação apresentada à Faculdade de \\ Odontologia de Ribeirão Preto da \\ Universidade de São Paulo, para a obtenção \\ do Título de Mestre em Ciências. \\ Programa: Odontopediatria \\ Área de Concentração: Odontopediatria \\ Orientadora: Profa. Dra. Maria Bernadete \\ Sasso Stuani
}


AUTORIZO A REPRODUÇÃO E DIVULGAÇÃO TOTAL OU PARCIAL DESTE TRABALHO, POR QUALQUER MEIO CONVENCIONAL OU ELETRÔNICO, PARA FINS DE ESTUDO E PESQUISA, DESDE QUE CITADA A FONTE.

Silvano,Paula Regina Ávila

Efeito do laser de baixa potência na vascularização da sutura palatina mediana, após a expansão rápida da maxila, em ratos wistar, Ribeirão Preto, 2015.

119 p.; II.; $30 \mathrm{~cm}$

Dissertação de Mestrado apresentada à Faculdade de Odontologia de Ribeirão Preto/USP - Área de concentração: Odontopediatria.

Orientadora: Stuani, Maria Bernadete Sasso

1. Ortodontia. 2. Terapia a Laser de Baixa Intensidade. 3. Vascularização. 4. Expansão rápida da maxila. 
SILVANO, PAULA REGINA ÁVILA

Efeito do laser de baixa potência na vascularização da sutura palatina mediana, após a expansão rápida da maxila, em ratos wistar.

Dissertação apresentada à Faculdade de Odontologia de Ribeirão Preto da Universidade de São Paulo, para a obtenção do Título de Mestre em Ciências.

Programa: Odontopediatria

Área de Concentração: Odontopediatria

Aprovado em:

Banca Examinadora

Prof. Dr.

Instituição:

Julgamento:

Assinatura:

Prof. Dr.

Instituição:

Julgamento:

Assinatura:

Prof. Dr.

Instituição:

Julgamento:

Assinatura: 


\title{
DADOS CURRICULARES
}

\author{
PAULA REGINA ÁVILA SILVANO
}

Nascimento: 01 de abril de 1975 - Uberaba/MG

Filiação: $\quad$ Jeanne Aparecida Ávila da Silva

Antonino Carlos da Silva

1993-1996 Curso de Graduação

Universidade de Uberaba - UNIUBE

2000-2001 Curso de Especialização em Odontopediatria

Universidade Estadual Paulista Júlio de Mesquita Filho - UNESP

2000-2001 Curso de Aperfeiçoamento em Ortopedia Funcional dos Maxilares ABO-MG

2004-2005 Curso de Especialização em Saúde Coletiva

Universidade Federal do Triângulo Mineiro - UFTM

2008-2010 Curso de Especialização em Ortodontia

ABO-MG

2013-2015 Curso de Pós Graduação em Odontopediatria, nível Mestrado.

Faculdade de Odontologia de Ribeirão Preto da Universidade de São Paulo - FORP/USP 


\title{
DEDICATÓRIA
}

À minha mãe, Jeanne Aparecida de Ávila, meu exemplo de dedicação profissional e retidão. Minha gratidão pelo seu apoio e companheirismo.

Às minhas filhas, Júlia e Mariana, que são tesouros na minha vida.

Aos meus padrinhos, José Maria e Doralice,que sempre me abençoaram com muito afeto.

À minha avó, Maria Rosa, que sempre esteve comigo e eu acredito que sempre estará.

Às minhas tias, Teresinha e Dora, que do jeito delas sempre estiveram vigilantes no apoio da minha criação.

À equipe Neo Odonto que segura as pontas na minha ausência da clínica para que eu possa estudar.

Aos pacientes que atendi durante todos esses anos de profissão, os quais também são razão de meu estudo continuado.

A todos que colaboraram comigo de alguma forma no encorajamento e confiança para que eu concluísse meu mestrado.

\section{“...AINDA QUE EU FALASSE A LÍNGUA DOS HOMENS , \\ E FALASSE A LÍNGUA DOS ANJOS....}

SEM AMOR EU NADA SERIA..."

\author{
“NÃO HÁ VENDAVAL QUE POSSA TIRAR VOCÊ DO CHÃO \\ OU DESMONTAR SUAS ESTRUTURAS,
}

SE VOCÊ TIVER DENTRO DE SI UMA TEMPESTADE DE FÉ...". 


\section{AGRADECIMENTOS}

À Faculdade de Odontologia de Ribeirão Preto da Universidade de São Paulo, na pessoa do atual Diretor Prof. Dr. Valdemar Mallet da Rocha.

À Coordenação do Curso de Pós-Graduação em Odontopediatria da Faculdade de Odontologia de Ribeirão Preto da Universidade de São Paulo, na pessoa da Prof ${ }^{a}$.Dr ${ }^{a}$.Raquel Assed Bezerra Segato e da Vice-Coordenadora Prof ${ }^{a}$.Dr ${ }^{a}$. Léa Assed Bezerra Segato.

À minha orientadora, Prof ${ }^{a}$.Dra. Maria Bernadete Sasso Stuani, pelo apoio, coompreensão e parceria em todos os momentos do curso. Agradeço pela sua confiança, paciência, oportunidade de aprender, crescer como profissional e como pessoa na convivência de dia-a-dia.

Aos Professores do Departamento de Clínica Infantil, da Faculdade de Odontologia de Ribeirão Preto da Universidade de São Paulo, cada um com seu jeito de ser $e$ profissionalismo me marcaram em minha vida profissional e pessoal de maneira positiva. Vou sempre lembrar de cada um, Prof ${ }^{a}$.Dr ${ }^{a}$. Aldevina Campos Freitas, Prof ${ }^{a}$.Dr ${ }^{a}$. Andiara de Rossi, Prof ${ }^{a}$.Dra . Kranya Victoria Díaz Serrano, Prof. Dr. Fábio Lourenço Romano, Prof. Dr. José Tarcísio Lima Ferreira, Profa.Dra. Léa Assed Bezerra da Silva, Prof ${ }^{a}$.Dra ${ }^{a}$. Maria da Conceição Pereira Saraiva, Prof ${ }^{a}$.Dr ${ }^{a}$. Maria Cristina Borsato, Prof. Dr. Mário Roberto Leonardo, Prof ${ }^{a}$.Dra. Mírian Aiko Nakame Matsumoto, Prof.Dr. Paulo Nelson Filho, Prof ${ }^{a}$.Dr ${ }^{a}$ Raquel Assed Bezerra Segato, pela experiência compartilhada e pelo exemplo de estudo e formação contínua profissional acadêmica e científica.

Aos funcionários do Departamento de Clínica Infantil da Faculdade de Odontologia de Ribeirão Preto cada um também com seu jeito especial na convivência durante os meus estudos me auxiliaram e orientaram da melhor maneira: Dra Carolina Paes Torres Montovani, Marco Antônio dos Santos, Nilza Letícia Magalhães, Fátima Aparecida Jacinto Daniel, Filomena Leli Placciti, Matheus Morelli Zanela e Micheli Cristina Leite Rovanholo sempre muito prestativa! 
Agradeço a colaboração e a amizade durante os estudos de Dr. Francisco Wanderlei Garcia de Paula e Silva, Gabriel Dessotti Barretto, Larissa Nogueira Soares Ribeiro, Maya Fernanda Manfrin Arnez, Elaine Machado Pingueiro Okada, Patrícia Maria Monteiro.

Aos Funcioários das clínicas, Benedita Viana Rodrigues, Fátima Aparecida Rizoli, Vera do Nascimento Scandelai e Karina Dadalt Quaglio agradeço pela gentileza e simpatia.

Aos funcionários do Biotério de Animais da Faculdade de Odontologia de Ribeirão Preto - FORP/USP, Antônio Sérgio Aparecido Mesca, Antônio Massaro e Aline Aparecida Ferraresi Tiballi, pela disposição e ajuda durante os procedimentos experimentais e cuidados com os animais.

Aos funcionários da Seção de Pós-Graduação da Faculdade de Odontologia de Ribeirão Preto da Universidade de São Paulo, Isabel Cristina Galino Sola e Mary Possani Carmessano, pela atenção e disposição.

Aos colegas da Pós-Graduação em Odontopediatria da Faculdade de Odontologia de Ribeirão Preto da Universidade de São Paulo, Ana Carolina Fumes, Carolina Maschietto Pucinelli, Cintia Guimarães de Almeida, Claudia María Carpio Bonilla, Daniela Silva Barroso de Oliveira, Daniele Lucca Longo, Danielly Cunha Araújo Ferreira, Denise de Souza Matos, Driely Barreiros de Oliveira, Elaine Machado Pingueiro Okada, Francine Lorencetti da Silva, Juliana Arid, Karina Alessandra Michelão Grecca Pieroni, Katharina Morant Holanda de Oliveira, Késsia Suênia Fidélis de Mesquita Guimarães, Larissa Nogueira Soares Ribeiro, Laura Alves Bastos, Lidia Regina da Costa Hidalgo, Mariana Alencar Nemezio, Mariana de Oliveira Daltoé, Mariele Andrade do Nascimento, Marina Moscardini Vilela, Nicole Gonçalves Lima, Patrícia Maria Monteiro, Priscilla Coutinho Romualdo, Raquel Fernanda Bachiega Morelli, Rodrigo Alexandre Valerio, Silvana Aparecida Frnandes Polizeli, Talitha de Siqueira Mellara e Thaís Aparecida Xavier, pela convivência e experiências trocadas, que sem dúvida fizeram parte da minha formação.

Aos Amigos Marília Rodrigues Moreira pelas boas conversas, incentivo profissional, caronas e amizade que construímos, Leonardo Gontijo Matos pela troca de experiências profissionais e pelas caronas também! E as amigas do primeiro dia que permaneceram 
parceiras Sofia Sampaio Meireles de Souza, Sara Silva de Oliveira e Maria Gabriela Flores Bracho.

Aos Professores da Banca, pela atenção dispensada na leitura desta dissertação.

A todos aqueles que não foram citados, mas contribuíram de alguma forma deste momento em minha vida. Muito obrigada! 


\section{RESUMO}

ÁVILA, P.R.S. Efeito do laser de baixa potência na vascularização da sutura palatina mediana, após a expansão rápida da maxila, em ratos wistar. 2015. 119f. Dissertação (Mestrado) - Faculdade de Odontologia de Ribeirão Preto, Universidade de São Paulo, Ribeirão Preto, 2015.

INTRODUÇÃO: O laser de baixa potência vem sendo utilizado em Odontologia com diversos objetivos, como diminuir o tempo de reparação de tecidos moles e duros. OBJETIVO: O presente trabalho in vivo teve como objetivo avaliar quantitativamente os efeitos do laser de baixa potência (LBP) com diodo de GaAlAs (Gálio-alumínioarsenieto), na vascularização dos tecidos da sutura palatina mediana após a expansão rápida da maxila (ERM) em ratos jovens, através da expressão do RNAm do gene Fator do Crescimento do Endotélio Vascular (VEGF) e da expressão protéica bem como a análise histológica. MATERIAL E MÉTODO: Utilizou-se 70 ratos Wistar (Rattus norvegicus, albinus), machos, pesando em média $220 \mathrm{~g}$, divididos em 3 grupos: Grupo Controle $(n=10)$ animais não tratados (sem ERM e sem aplicação do LBP; Grupo Experimental I $(n=30)$ animais que tiveram apenas a ERM. Grupo Experimental II $(n=30)$ animais que receberam 3 aplicações de LBP (nos primeiros 3 dias do experimento) após ERM, totalizando $160 \mathrm{~J} / \mathrm{cm}^{2}$. Os animais do Grupo Controle foram sacrificados no dia 0 e os os animais dos Grupos Experimentais I e II sacrificados nos dias 3, 7, e 10 dias após a ERM, sendo 15 animais destinados a análise com RT-PCR e western blotting e 15 animais à análise histológica. A extração do RNAt da maxila foi feita com trizol. A síntese da fita de DNA complementar (cDNA) foi feita a partir de $1 \mu \mathrm{g}$ de RNA, por meio de uma reação de transcrição reversa, com a utilização da enzima transcriptase reversa, e a análise da expressão gênica foi realizada pela reação em cadeia pela polimerase em tempo real (qRT-PCR) no sistema TaqMan®. A análise protéica do VEGF, foi realizada por meio da técnica western blotting. Os dados foram agrupados e apresentados como médias e desvios-padrão (contínuas variáveis) ou medianas, intervalos interquartil, e os valores mínimos (variáveis ordinais) e máximo. O teste de variância (ANOVA) foi usado comparando os grupos entre si e inter-grupos seguida pelo teste complementar de Tukey, com nível de significância de 5\%. O teste Kruskal-Wallis, testes de Dunn $(p<0,05)$ foram utilizados para mediana, amplitude interquartil, valores máximos e mínimos dos escores do número de células inflamatórias. RESULTADOS: Em relação à expressão relativa do gene VEGF tanto o grupo com laser quanto o sem-laser mostraram um aumento significativo da expressão comparado ao grupo controle $(p<0,05)$, principalmente nos períodos iniciais e quando se comparou o grupo irradiado com o não irradiado observou-se que no grupo com laser houve uma maior expressão desses genes do que no grupo sem laser. CONCLUSÃO: Os resultados sugerem que a formação óssea após a ERM foi observada dentro da sutura palatina e o uso do LBP influenciou a formação óssea acelerando o processo de osteogênese e a vascularização durante a fase inicial do experimento.

Palavras-chave: Ortodontia; Terapia a Laser de Baixa Intensidade; Laserterapia, Vascularização; Expansão rápida da maxila. 


\begin{abstract}
ÁVILA, P.R.S. Low-level laser effect on vascularization of the midpalatal suture, after rapid maxillary expansion, in Wistar rats. 2015. 119f. Dissertation. Faculdade de Odontologia de Ribeirão Preto da Universidade de São Paulo, Ribeirão Preto, 2015.
\end{abstract}

BACKGROUND: The low-level laser terapy (LLLT) has been used in Dentistry with many objectives. OBJECTIVE: The aim of the present in vivo study was to quantitatively evaluate the effects of low-level laser therapy (LLLT) GalliumAluminum-Arsenide (GaAlAs) on the vascularization after rapid maxillary expansion (RME) in young rats, and the VEGF gene and protein expressions; and histological analyses. MATERIALS and METHODS: A total of 70 rats Wistar (Rattus norvegicus, albinus), male, weighing $220 \mathrm{~g}$, were assigned to three groups: Control Group $(n=10)$ with no treatment (no RME and no LLLT); Experimental I $(n=30)$ with RME without LLLT; Experimental II $(n=30)$ with RME and and 3 aplication of LLLT $\left(160 \mathrm{~J} / \mathrm{cm}^{2}\right)$. The rats of Control Group were euthanized at day 0 and the animals of Experimental I and II Groups were euthanized at days 3, 7 and 10 after RME for real time reverse transcriptase polymerase chain reaction (RT-PCR) and western blotting analysis and for histological evaluation. Part of the sample was kept at $-80^{\circ} \mathrm{C}$ for genes expression and protein production, and another for histological analysis. The total RNA was extracted using trizol. Complementary DNA (cDNA) was synthesized using $1 \mu \mathrm{g}$ of RNA in a reverse transcription reaction and for genes expression we used RT-PCR in the TaqMan ${ }^{\circledR}$ system. The VEGF and proteins analysis was made using western blotting. Data were grouped and presented as means and standard deviations (continuous variables) or medians, interquartile ranges, and maximum and minimum values (ordinal variables). The ANOVA and Tukey tests were used and significance level was set at $5 \%$. Medians, interquartile ranges, and maximum and minimum values of the numbers scores for cells inflamatory $(P<0.05$; Kruskal-Wallis, Dunn tests). RESULTS: Regarding VEGF gene and protein expression, both laser and nolaser therapy groups showed a significant increased in these genes expression, compared to the control group, mainly at the initial periods of healing. Laser therapy group showed a higher expression of these genes than no laser group. CONCLUSIONS: The results suggest that bone formation after RME was observed within palatal suture and the application of the LLLT influenced bone formation accelerating the process of bone mineralization during the initial experimental phase.

Keywords: Orthodontics; Low-Level Laser Therapy; Laser therapy; Vascularization; Rapid maxilla expansion. 


\section{LISTA DE ILUSTRAÇÕES}

Quadro 1 - Distribuição da amostra de acordo com os períodos de exprimento e irradiação com laser

Figura 1 - Vista oclusal mostrando a mola utilizada para a ERM colocada entre os incisivos centrais

Quadro 2 - Protocololo de irradiação utilizado

Figura 2 - Vista oclusal durante irradiação de laser na sutura palatina mediana, com o dispositivo ortodôntico entre os incisivos centrais

Quadro 3 - Escore de grau de inflamação.

Figura 3 - Região da sutura palatina mediana do grupo controle. A) e B) visão panorâmica mostrando a sutura palatina mediana da porção cervical até a região nasal. $O$ tecido conjuntivo sutural (TC) está envolto por tecido ósseo (O) e delimitado pelas fossas nasais (FN) e pelas coroas dos incisivos superiores (IS). C) Detalhe da sutura onde é possivel verificar osteoblastos (OB) delimitando a superfície óssea (setas brancas) e vasos sanguíneos $(\mathrm{V})$ por toda extensão do tecido sutural e presença de fibras colágenas (FC) inseridas no tecido ósseo

Figura 4 - Região da sutura palatina mediana do grupo Experimental I (3 dias). A) visão panorâmica mostrando a sutura palatina mediana onde observa intensa hemorragia $\left({ }^{*}\right)$. Em B) observa-se as fibras colágenas (FC) aderidas a parede óssea. C) Presença de fibras colágenas (FC) inseridas no tecido ósseo. D).

Figura 5 - Região da sutura palatina mediana do grupo Experimental I ( $\left.7^{\circ} \mathrm{dia}\right)$. A) visão panorâmica mostrando a sutura palatina mediana onde ainda observa área hemorragica $\left({ }^{*}\right)$. Em B) observa-se tecido conjuntivo com células inflamatórias $(\mathrm{Cl})$ e vasos sanguíneos (setas brancas). C) e D) Presença de osteoclastos (OC) na superfície interna da sutura palatina (setas pretas) e células inflamatórias $(\mathrm{Cl})$.

Figura 6 - Região da sutura palatina mediana do grupo Experimental I (10 $\mathrm{dia})$. A) visão panorâmica mostrando a sutura palatina mediana sem área hemorrágica. $\mathrm{Em} \mathrm{B}$ ) observa-se intensa proliferação de fibras colágenas. C) e D) Presença de osteoblastos revestindo o tecido ósseo (seta branca) recém formado e fibroblastos distribuídos pelo tecido conjuntivo (TC) e vasos sanguíneos (VV).

Figura 7 - Região da sutura palatina mediana do grupo Experimental II (dia 3). A) visão panorâmica mostrando a sutura palatina mediana com áreas hemorrágicas $\left(^{*}\right)$ em toda extensão da sutura. B) C) e D) observam-se fibras colágenas (FC) aderidas na superfície óssea $(\mathrm{O})$......

Figura 8 - Região da sutura palatina mediana do grupo Exp II ( $7^{\circ}$ dia). A) visão panorâmica mostrando a sutura palatina mediana com intensa proliferação de fibras colágagenas e vasos sanguíneos. B) observam-se fibras colágenas (FC) distribuídas em diversas direções repleto de vasos sanfguíneos (VV) e osteoblastos (setas vazadas) recobrindo a superfície óssea. C) osteoblastos (OB) ativos na superfície óssea e a linha de repouso entre o tecido ósseo antigo e o tecido ósseo novo (setas). D) Tecido ósseo neo-formado (O) repleto de vasos sanguíneos (VV). 
Figura 9 - Região da sutura palatina mediana do grupo Experimental II ( $10^{\circ}$ dia). A) visão panorâmica mostrando a sutura palatina mediana com intensa proliferação de fibras colágagenas. B) observam-se fibras colágenas (FC) distribuídas em diversas direções e osteoblastos (setas pretas) recobrindo a superfície óssea.

Quadro 4 - Escore individual de cada espécime e mediana de cada grupo para a intensidade do processo inflamatório em todos os períodos para o Grupo Controle e experimentais ..... 81

Figura 10 - Expressão da mediana, amplitude interquartil, valores máximos e mínimos dos escores de número de células inflamatórias ( $p<0,05$; Kruskal-Wallis, teste de Dunn). Os dados correspondem a 10 dias de experimento.

Figura 11 - Expressão de RNAm VEGF no Grupo Experimental I, II e Controle. Os dados correspondem a 10 dias de experimento, comparado com o controle. Os resultados estão expressos em média e desvio padrão. ${ }^{*} p<0,05 ;{ }^{* *} p<0,001$, ns=não significante.

Figura 12 - Expressão de RNAm VEGF no Grupo Experimental I e II. Os dados correspondem a 10 dias de experimento. Os resultados estão expressos em média e desvio padrão. ${ }^{*} p<0,05 ;{ }^{* *} p<0,01 ;{ }^{* * *} p<0,001 ; n s=$ não significante

Figura 13 - Gráfico dos valores densitométricos das bandas utilizadas para a proteína VEGF do grupo experimental I, II e Controle, durante a osteogênese após a ERM nos diversos períodos analisados. Os resultados estão expressos em média e desvio padrão. ${ }^{*} p<0,05$; ${ }^{* *} \mathrm{p}<0,01 ;{ }^{* * *} \mathrm{p}<0,001 ; \mathrm{ns}=$ não significante.

Figura 14 - Gráfico dos valores densitométricos das bandas utilizadas para a proteína VEGF do grupo experimental I e II, durante a osteogênese após a ERM nos diversos períodos analisados. Os resultados estão expressos em média e desvio padrão. ${ }^{*} p<0,05$; ${ }^{* *} p<0,01$; ${ }^{* * *} p<0,001 ; n s=$ não significante 


\section{LISTA DE ABREVIATURAS E SIGLAS}

\begin{tabular}{|c|c|}
\hline Al-Ga-As & Alumínio-gálio-arsenieto \\
\hline cDNA & DNA complementar \\
\hline CEUA & Comissão de ética no uso de animal \\
\hline CT & Threshold cycle \\
\hline DEPC & Dietilpirocarbonato \\
\hline DNA & Ácido desoxirribonucleico \\
\hline EDTA & Etilenodiaminotetracetatodissódico \\
\hline ERM & Expansão rápida da maxila \\
\hline FC & Fibras Colágenas \\
\hline FGF & Fator de crescimento de fibroblasto \\
\hline $\begin{array}{l}\text { FORP- } \\
\text { USP }\end{array}$ & $\begin{array}{l}\text { Faculdade de Odontologia de Ribeirão Preto da Universidade de São } \\
\text { Paulo }\end{array}$ \\
\hline GC & Grupo Controle \\
\hline $\mathrm{H} / \mathrm{E}$ & Coloração hematoxilina e eosina \\
\hline $\lg G$ & Imunoglobulina G \\
\hline Laser & $\begin{array}{l}\text { Light amplification by stimulated emission of radiation (Amplificação } \\
\text { da luz por emissão estimulada da radiação) }\end{array}$ \\
\hline LBP & Laser de baixa potência \\
\hline LLLT & Low-level laser therapy \\
\hline mRNA & Ácido ribonucléico mensageiro \\
\hline $\mathrm{Nm}$ & O número de células imunomarcadas por $\mu \mathrm{m}^{2}$ \\
\hline OCIF & Fator inibitório da osteoclastogênese \\
\hline OPG & Osteoprotegerina \\
\hline PBS & Solução tampão de fosfato de sódio \\
\hline PCR & Reação em cadeia pela polimerase \\
\hline $\mathrm{PGE}_{2}$ & Prostaglandina \\
\hline $\mathrm{pH}$ & Potencial hidrogêniônico \\
\hline RANK & Receptor ativador do fator nuclear kappa $\beta$ \\
\hline RANK-L & Ligante do receptor ativador kappa $\beta$ \\
\hline RME & Rapid maxillary expansion \\
\hline RNA & Ácido ribonucleico \\
\hline RNAt & Ácido ribonucleico total \\
\hline RT-PCR & Transcrição reversa seguida da pcr \\
\hline RUNX-2 & Fator de transcrição relacionado ao Runt-2 \\
\hline
\end{tabular}


TGF- $\alpha$ Fator de crescimento transformador alfa

TNF Fator de necrose tumoral

TNF $\alpha \quad$ Fator de necrose tumoral- $\alpha$

TRAP Tartrate-resistant acid phosphatase (Fosfatase ácida tártaroresistente)

USP Universidade de São Paulo

VEGF Fator de crescimento endotelial vascular 


\section{LISTA DE SÍMBOLOS}

\begin{tabular}{|c|c|}
\hline$\%$ & Expressa um valor em percentual \\
\hline${ }^{\circ} \mathrm{C}$ & Graus centígrados (Celsius) \\
\hline g & Gramas \\
\hline J & Joules \\
\hline $\mathrm{J} / \mathrm{cm}^{2}$ & Joules por centímetro quadrado \\
\hline $\mathrm{mg}$ & Micrograma \\
\hline $\mathrm{ml}$ & Mililitro \\
\hline $\mathrm{mg} / \mathrm{kg}$ & Miligrama por quilograma \\
\hline $\mathrm{mm}$ & Milímetro \\
\hline $\mathrm{mm}^{2}$ & Milímetro quadrado \\
\hline $\mathrm{mg} / \mathrm{ml}$ & Miligramas por mililitro \\
\hline $\mathrm{mW}$ & miliwats \\
\hline $\mathrm{cm}^{2}$ & Centímetro quadrado \\
\hline M & Molar \\
\hline $\mathrm{Ng}$ & Nanograma \\
\hline$\mu \mathrm{m}$ & Micrometro \\
\hline$\mu g$ & Micrograma \\
\hline$\mu \mathrm{l}$ & Microlitro \\
\hline$\mu \mathrm{g} / \mu \mathrm{l}$ & Nanograma por nanolitro \\
\hline$+/-$ & Média \\
\hline$\Delta \mathrm{Ct}$ & Delta Ct \\
\hline$\mu \mathrm{g} / \mu \mathrm{l}$ & Micrograma/Mililitro \\
\hline$d p$ & Desvio padrão \\
\hline $\mathrm{Hz}$ & Hertz \\
\hline$p$ & Valor-p \\
\hline $\mathrm{pH}$ & Potencial hidrogeniônico \\
\hline
\end{tabular}




\section{SUMÁRIO}

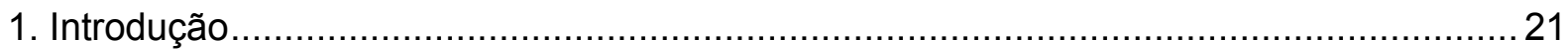

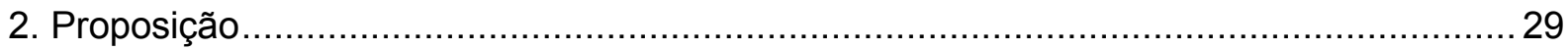

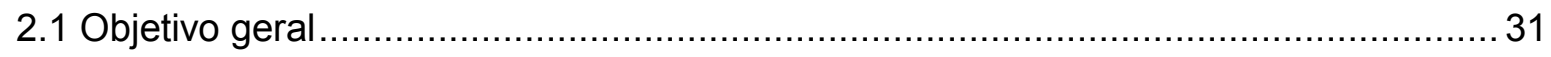

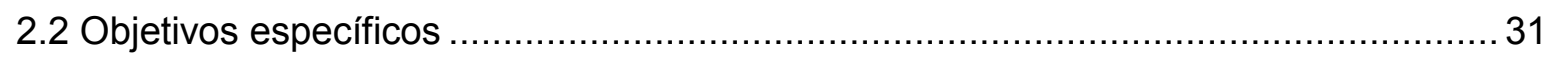

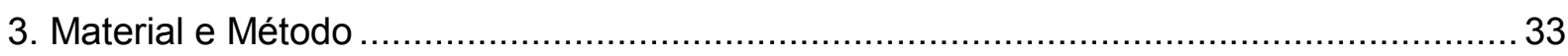

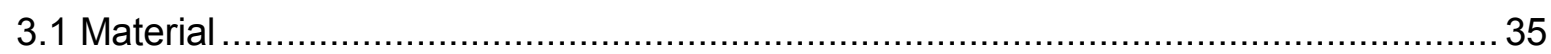

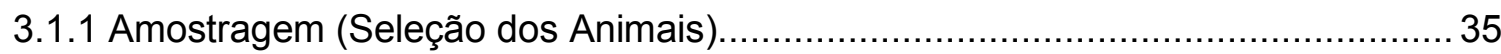

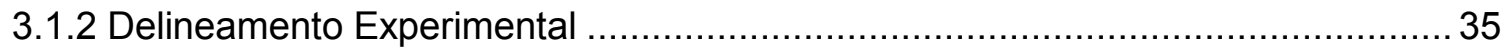

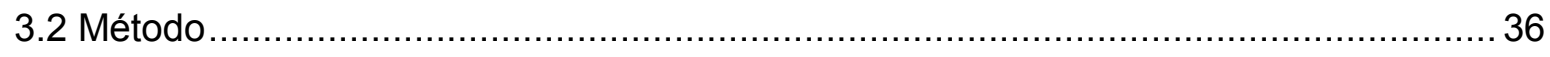

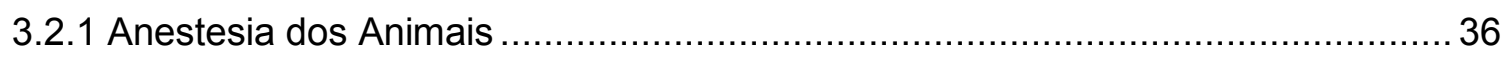

3.2.2 Instalação e Ativação do Dispositivo Ortodôntico para a Disjunção da Sutura

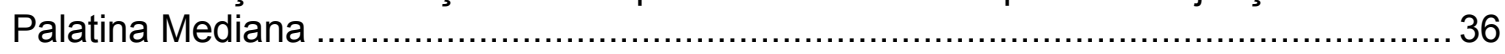

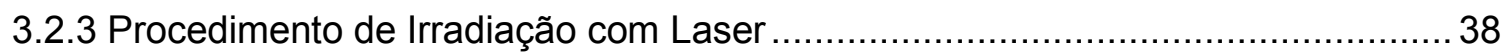

3.2.4 Eutanásia dos Animais, coleta e preparo dos espécimes ............................... 40

3.2.5 Metodologias para Avaliar a Vascularização e a Expressão Gênica do VEFG após

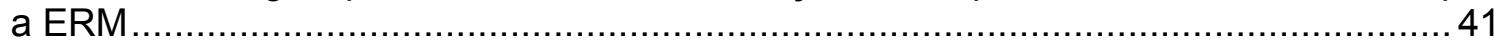

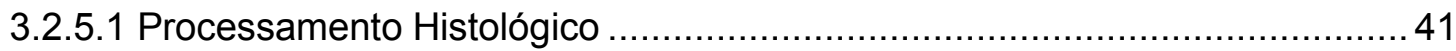

3.2.5.2 Análise da Expressão Gênica........................................................... 42

3.2.5.2.1 Extração, Isolamento e Avaliação do RNA total ................................... 42

3.2.5.2.2 Analise da Expressão do mRNA pela PCR em Tempo Real.................... 43

3.2.5.3 Expressão das Proteinas ..................................................................... 44

3.2.5.3.1 Western Blotting ................................................................. 44

3.2.5.3.1.1 Extração e quantificação de proteína total .................................... 45

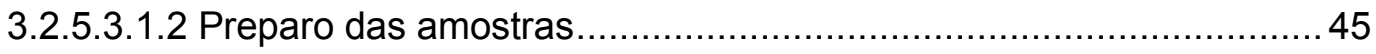

3.2.5.3.1.3 Corrida das proteínas no gel de poliacrilamida e transferência das proteínas para a membrana de nitrocelulose ............................................. 46

3.2.5.3.1.4 Imunomarcação e a evidenciação das proteínas na membrana de

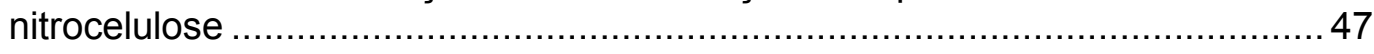

3.2.5.3.1.5 Análise histométrica ......................................................... 48

3.2.5.3.2 Análise histométrica do tecido inflamatório. ..................................... 49

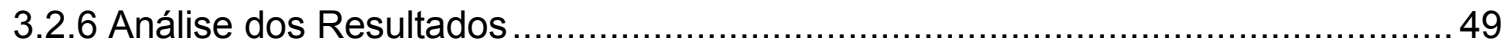

3.2.6.1 Precisão da Metodologia (Calibração do examinador)............................... 49

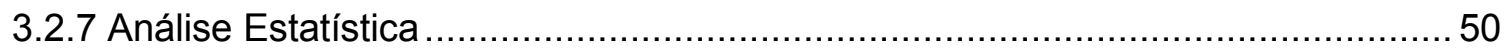

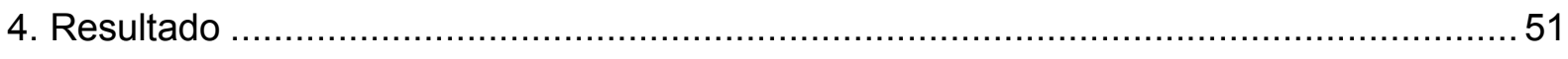

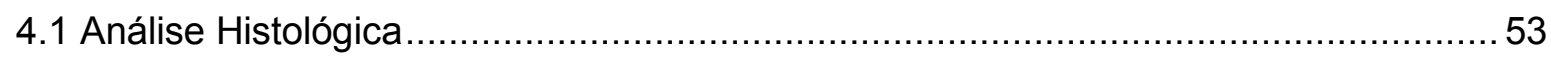

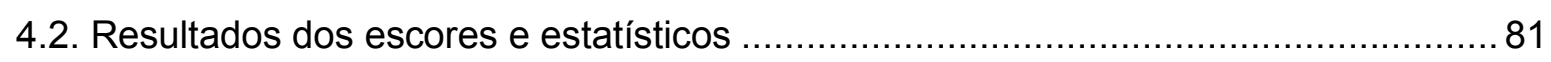

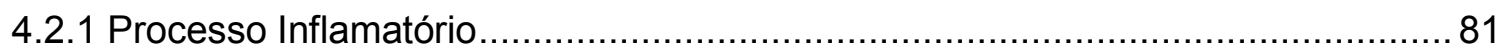

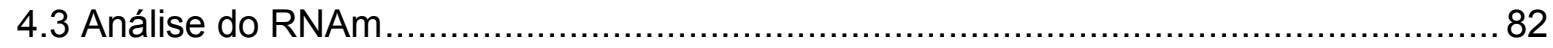

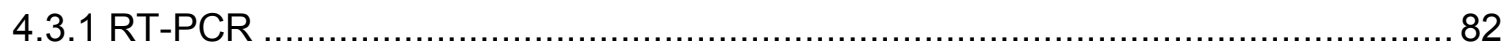


4.3.2 Análise da expressão de proteína - Western Blotting ....................................... 84

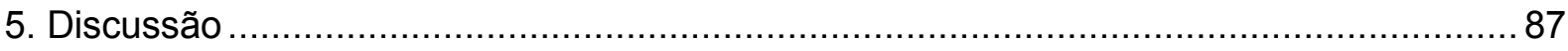

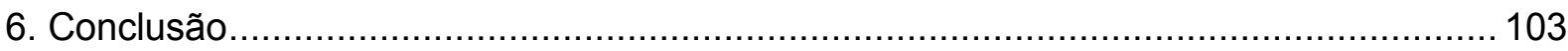

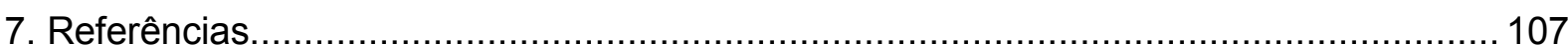

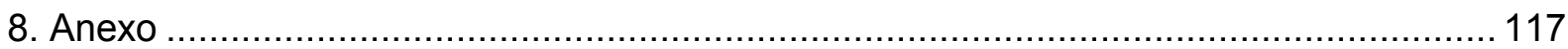





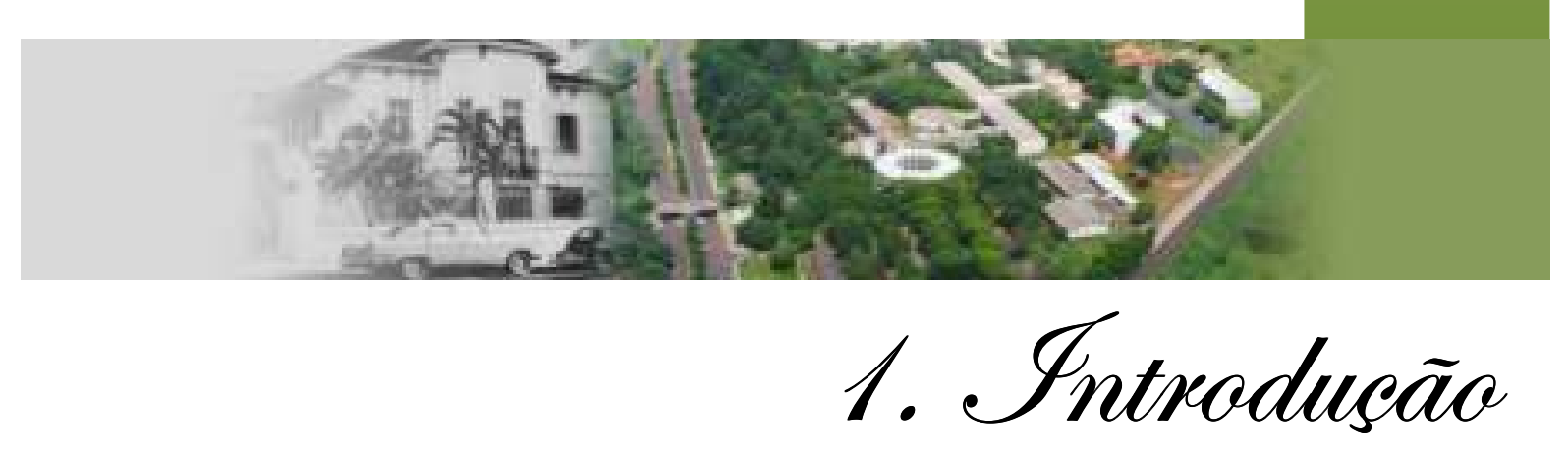





\section{INTRODUÇÃO}

A primeira necessidade de mudança estrutural do tecido ósseo surge quando as trabéculas de osso primário estão sendo formadas. O aumento na espessura da trabécula aumenta a distância entre os osteócitos da região central da trabécula e a superfície óssea, onde está a vascularização, e os primeiros osteoclastos então aparecem na região. Os osteoblastos de uma determinada área, cessam a deposição da matriz, degradam o osteóide e se afastam da superfície óssea, sofrendo apoptose. Os osteoclastos se aderem à matriz mineralizada, e, iniciam o processo de reabsorção. Em geral, vários osteoclastos adjacentes reabsorvem uma área determinada, e, quando estes, terminam a fase de reabsorção, afastam-se da matriz, sofrendo também apoptose. Células indiferenciadas são atraídas para a região, diferenciando-se em novos osteoblastos, os quais inicialmente depositam as proteínas não colágenas (osteopontina e sialoproteína óssea), que, devido às suas propriedades adesivas, desempenham importante papel na adesão entre a superfície mineralizada onde parou a reabsorção e a nova matriz óssea é secretada. Dessa maneira, uma linha cimentante é formada entre ambas as matrizes. Por ser essa uma linha cimentante originada entre a superfície reabsorvida e a nova matriz depositada, denomina-se linha de reversão. Existe outro tipo de linha cimentante que é a de deposição óssea. Os osteoblastos passam períodos de repouso e neo-formação, e, quando os osteoblastos retomam a deposição de matriz, em geral primeiro depositam as duas proteínas não colágenas adesivas, formando uma linha cimentante do tipo aposicional. As linhas aposicionais são lisas e regulares, enquanto as linhas de reversão são irregulares, especialmente quando vistas ao microscópio eletrônico de transmissão. As linhas cimentantes são numerosas no tecido ósseo e revelam a intensa remodelação que ocorre neste tecido (GARANT, 2003; BASKAR, 1989).

A remodelação óssea não ocorre somente durante o crescimento ósseo. Algumas áreas são reabsorvidas, enquanto outras são neoformadas de maneira alternada durante toda a vida. Isso é devido à adaptação do osso à função, aos estímulos, principalmente locais, e à necessidade de renovar pequenas áreas eventualmente microfraturadas pelos impactos. Os dois processos ocorrem 
alternadamente, sendo que o desequilíbrio gera desordens como a osteoporose, na qual a atividade reabsortiva é maior que a formativa, resultando na diminuição da massa óssea, com a consequente queda na resistência dos ossos e sua predisposição a fraturas (KATCHBURIAN; ARANA, 1999; ARANA, 2012).

A presença de citocinas angiogênicas como o VEGF (Fator de Crescimento Endotelial Vascular) em células é primordial para que ocorra o processo de neovascularização permitindo a remodelação óssea. A reação inflamatória local desencadeia eventos vasculares e celulares (VANDEVSKA-RADUNOVIC, 1999). O exsudato inflamatório gerado pela aplicação de forças ortodônticas apresenta em sua composição mediadores plasmáticos como fibrina, plasmina, cininas, imunoglobulinas e proteínas. Os Mediadores de células teciduais residentes e inflamatórias, como a prostaglandina (PGE2), leucotrienos, citocinas, fator de necrose tumoral (TNF), fatores de crescimento (EGF, PGDF, FGF-2) também estão presentes (DAVIDOVITCH, 1991).

Quando se aplica força ortodôntica sobre um dente ocorre hipóxia local, e o estresse funcional nas células sob tensão (fibroblastos, cementoblastos, osteoblastos e clastos) produz modificações ambientais e alterações no colágeno e forma áreas hialinas. As modificações teciduais se relacionam à remodelação por ativação da reabsorção óssea alveolar no lado de pressão e aposição no lado de tração (SALOMÃO, 2005). O osso é removido seletivamente e adicionado em outras áreas enquanto se move carregando os tecidos de sustentação (PROFFIT, 2002). $\mathrm{Na}$ verdade precisa mais que reabsorver e adicionar; é um processo dinâmico onde as atividades celulares devem estar coordenadas entre osteoblastos, osteócitos e osteoclastos mantendo a homeostasia do tecido mineral (KRISHNAN e DAVIDOVITCH, 2009).

Em forças ortodônticas suaves aos dentes, a primeira resultante é a interrupção do suprimento sanguíneo, provocando uma necrose estéril (região hialinizada), e um processo inflamatório próximo ao tecido hialinizado. Há também diminuição do oxigênio devido à compressão dos vasos sanguíneos da região induzindo a secreção de mediadores que vão contribuir para restabelecer a oxigenação posteriormente (SALOMÃO, 2005; SANDY, 1992; KRISHNAN e DAVIDOVITCH, 2009). Quanto maior a hipóxia gerada maior a hialinização, o que depende da força aplicada para a movimentação ortodôntica ocorrer. Em função do 
ph ácido do exsudato formado na região, células clásticas se instalam e promovem a reabsorção óssea. A remodelação próxima à área hialinizada é realizada por células derivadas de regiões adjacentes não danificadas, principalmente pelos macrófagos. Os macrófagos são essenciais para remoção do exsudato, restos protêicos e celulares que se formam na área de compressão. Eles têm ação quimiotática, e, estimulam a proliferação e síntese de células mesenquimais, endoteliais, fibroblastos e osteoblastos, para que haja recolonização e reorganização da área tecidual (CONSOLARO, 2005). Ao mesmo tempo que os macrófagos atuam, os osteoclastos iniciam ataque abaixo da área necrótica o que se denomina reabsorção óssea solapante (PROFFIT, 2002). No lado oposto, onde há distensão das fibras colágenas, o estímulo promove diferenciação de células mesenquimais em osteoblastos e fibroblastos formadores de tecido ósseo e fibras colágenas (PROFFIT, 2002; KRISHNAN e DAVIDOVITCH, 2009).

Porém, nos casos de expansão rápida da maxilla (ERM), na sutura palatina mediana predomina o estiramento e rompimento das fibras colágenas. Como a força aplicada é de grande magnitude durante a ERM, ocorre estiramento e o rompimento de algumas fibras colágenas, processo inflamatório inicial e presença de áreas hemorrágicas. A inflamação é um requisito para a remodelação óssea, onde ocorre vasodilatação com aumento de permeabilidade vascular, aumento do fluxo sanguíneo, exsudação de fluidos e migração leucocitária para o espaço extravascular (DAVIDOVITCH, 1991). A tração das fibras da sutura durante a ERM induz estímulos geradores de inflamação local que gera um microambiente susceptível à remodelação óssea (CONSOLARO, 1999). Assim, a distorção seria o estímulo primário, mas, a presença das fibras é necessária para transferir a força inicial (ZENGO; PAWLUK; BASSETT, 1973; HELLER; NANDA, 1979). Portanto, após a ERM ocorre uma série de eventos vasculares como a formação de exsudato inflamatório circunjacente à área envolvida; liberação de proteínas livres; hipóxia ou anóxia local decorrentes da destruição celular ou desorganização de fibras colágenas e matriz extracelular (DAVIDOVITCH, 1991; GAENGLER; MERTE, 1983). As forças induzidas experimentalmente produzem alteração do fluxo sanguíneo devido às reações vasculares (KRISHNAN e DAVIDOVITCH, 2009). Essas alterações são mediadas por fatores de crescimento angiogênicos como o VEGF.

O VEGF desempenha papel na angiogênese, vasculogênese e formação de 
matriz colágena que são essenciais na reorganização do tecido periodontal e ósseo. A angiogênese é um processo fundamental para a formação de novos vasos sanguíneos a partir de capilares pré-existentes (CHAIN; JONES; TARNAWSKI, 2004). É um evento importante em vários fenômenos fisiológicos tais como no desenvolvimento embrionário, inflamação e no reparo tecidual (POLVERINI, 1995). Levando-se em consideração essas condições, a angiogênese é altamente regulada, e inicia-se sobre breves períodos (dias), e então, é inibida completamente (FOLKMAN; SHING, 1992). Entretanto, muitas doenças são ocasionadas pela persistência do processo de angiogênese, devido à neovascularização desregulada (FOLKMAN; KLAGSBRUN, 1987; FOLKMAN; SHING, 1992).

A angiogêsene envolve mecanismos de formação de capilares a partir de vasos já existentes. Em adultos é um fenômeno transitório, regulado e associado à ciclos reprodutivos, ou à processos de reparo (PLATE et al., 1994). A cicatrização das feridas se dá pelo aumento do fluxo vascular e o contrário poderia levar à regressão de tumores, metastases e, diminuir a intensidade de fenômenos imunomediadores e inflamatórios.

As células endoteliais, geralmente quiescentes, adquirem fenótipo angiogênico. Capilares sanguíneos são constituídos por células epiteliais e pericitos, que contêm informações genéticas para a formação de tubos, ramificações e redes capilares (FOLKMAN; SHING, 1992). Em condições fisiológicas os pericitos mantêm a célula endotelial quiescente e evitam sua proliferação (PEPPER et al., 1992).

O fator de crescimento vascular endotelial (VEFG) é um mitógeno potente para o endotélio vascular, modulando a expressão de muitas enzimas proteolíticas envolvidas no processo de angiogênese. O VEGF foi isolado inicialmente em fluidos tumorais onde foi observada a capacidade de induzir aumento da permeabilidade vascular (SENGER et al., 1983). VEGF é capaz de regular todos os passos do processo de neovascularização e é importante nos processos fisiológicos e patológicos da angiogênese, no sistema reprodutivo feminino e em outros tecidos. VEGF é encontrado em muitas áreas em tecidos adultos, indicando que ele é importante não somente no processo de angiogênese, mas também no processo de manutenção de vasos existentes (CHARNOCK-JONES; HE; SMITH, 2002).

O estado de hipóxia vascular humana, em células musculares lisas, promove um aumento na expressão de VEGF. Citocinas e fatores de crescimento (PGE2 e 
PGE1), fator de crescimento like insulina (IGF), fator de crescimento derivado de plaquetas e 1-a-dihidroxivitamina D3 fazem aumentar a expressão de VEGF em osteoblastos e em células semelhantes (HARADA et al., 1994; WONG et al., 1996; GOEDE et al., 1998).

VEGF é um mitógeno específico para as células endoteliais, produzido por vários tipos celulares, como queratinócitos, macrófagos, mastócitos e fibroblastos (NÖR et al., 1999; FERRARA, 2004). O mesmo também é conhecido por aumentar a permeabilidade vascular e estar envolvido na ocorrência e progressão do processo inflamatório (DVORAK et al., 1995). VEGF é 50.000 vezes mais potente do que a histamina na capacidade de aumentar a permeabilidade vascular (DVORAK, 2002; HICKLIN; ELLIS, 2005).

Algumas implicações clínicas interessantes do VEGF estão relacionadas ao seu envolvimento no processo de angiogênese óssea e formação óssea endocondral. A aplicação desse fator de crescimento vascular endotelial pode ser útil para melhorar o processo de revascularização em casos de fraturas não consolidadas e em outras condições (FERRARA; GERBER; LeCOUTER, 2003), como por exemplo, em casos de necroses ósseas (KATSUBE et al., 2005).

Trabalhos como o de Booth et al. (1998) demonstraram a presença do VEGF na doença periodontal inflamatória crônica, mas também, observaram a presença de VEGF em áreas livres de inflamação (periodonto saudável) ratificando o papel do mesmo na angiogênese fisiológica da gengiva e ambiente periodontal. A presença de VEGF na mucosa oral também foi observada por CARLILE et al. (2001).

O laser de baixa potência tem sido citado pelos seus efeitos bioestimulatórios em diversas situações clínicas, sendo efetivo na aceleração da cicatrização de tecidos moles (MESTER; MESTER; MESTER, 1985). Em Odontologia, o laser tem várias aplicações, podendo ser empregado como auxiliar terapêutico na hipersensibilidade dentinária, em lesões traumáticas da mucosa, gengivites, periodontites, pericementites, herpes simples entre outros (PINHEIRO et al., 1998; PINHEIRO; GERBI, 2006). Por sua atuação em tecido duro, acelerando a reparação óssea, o laser poderia ser empregado em tratamento ortodôntico, extração dental, cirurgia ortopédica e implantes entre muitos outros procedimentos realizados na Odontologia que seriam beneficiados por seu potencial bioestimulatório (KAWASAKI; SHIMIZU, 2000). 
Alguns estudos experimentais em animais e observações clínicas mostraram evidências de que a luz laser acelera o processo de reparação tecidual, induzindo a atividade mitótica celular, modificando a densidade capilar e aumentando a síntese de colágeno. O conhecimento do mecanismo da ação do laser no tecido ósseo é fundamental para que as aplicações clínicas tornem-se mais seguras e eficazes. Alguns autores trabalharam in vitro com osteoblastos isolados de calvária de ratos, principal célula responsável na reparação óssea, submetidos ao laser de baixa potência (OSAWA et al., 1998; UEDA; SHIMIZU, 2001, 2003). Estes estudos se correlacionam com outros in vivo que mostraram maior rapidez na recuperação de fraturas ósseas e aumento da reparação óssea em tratamentos ortopédicos respectivamente (TRELLES; MAYAYO, 1987; SAITO; SHIMIZU, 1997).

A Ortodontia tem como objetivo a correção das maloclusões esquelética e dentária utilizando forças ortodônticas e ortopédicas aplicadas no tecido ósseo. Estas forças desencadeiam diversas respostas nos tecidos tanto a nível histológico quanto molecular que resultará em remodelação óssea (MEIKLE, 2006). Sabe-se que a formação óssea depende do suprimento sanguíneo, e que o tecido ósseo, é uma fonte rica em fatores angiogênicos e de crescimentos endotelial e ósseo. Como o VEGF é o regulador mais importante tanto da neovascularização fisiológica quanto da patológica é fundamental o conhecimento desses fatores angiogênicos dentro da Ortodontia. Estudos têem sidos realizados em relação a vascularização durante a movimentação dentária experimental (KANZAKI et al., 2001), mas não existe nenhum trabalho relacionando o VEGF quando da aplicação de uma força ortopédica, como no caso da expansão rápida da maxila (ERM) e aplicação do laser de baixa potência (LBP), para estimular o reparo ósseo.

Como a literatura tem mostrado que o laser de baixa potência induz a formação de tecido ósseo, a atual pesquisa teve como objetivo correlacionar a vascularização com a expressão da proteína VEGF durante a osteogênese induzida após a disjunção maxilar e aplicação do LBP, em ratos. 


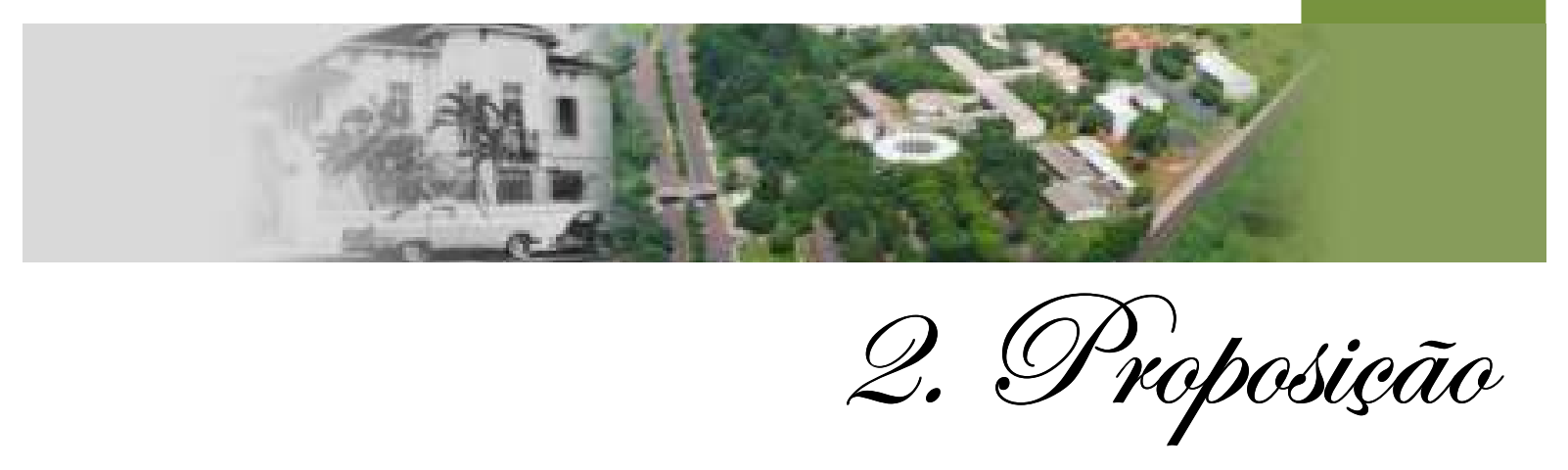





\section{PROPOSIÇÃO}

\subsection{Objetivo geral}

O objetivo do presente estudo é avaliar in vivo a influência da aplicação do laser de baixa potência, sobre a vascularização durante o processo de remodelação óssea, por meio da expressão do gene e da proteína VEGF envolvida nesse processo, após a expansão rápida da maxila.

\subsection{Objetivos específicos}

1. Descrever histologicamente os eventos celulares e vasculares que ocorrem na sutura paralatina mediana após a ERM (com e sem a aplicação do laser de baixa potência).

2. Quantificar o número de perfis de células inflamatórias no tecido sutural (com e sem a aplicação do laser de baixa potência).

3. Quantificar a expressão do gene e da proteína (VEGF), no tecido ósseo submetido à força ortopédica (com e sem a aplicação do laser de baixa potência), por meio do PCR e Western Blotting. 



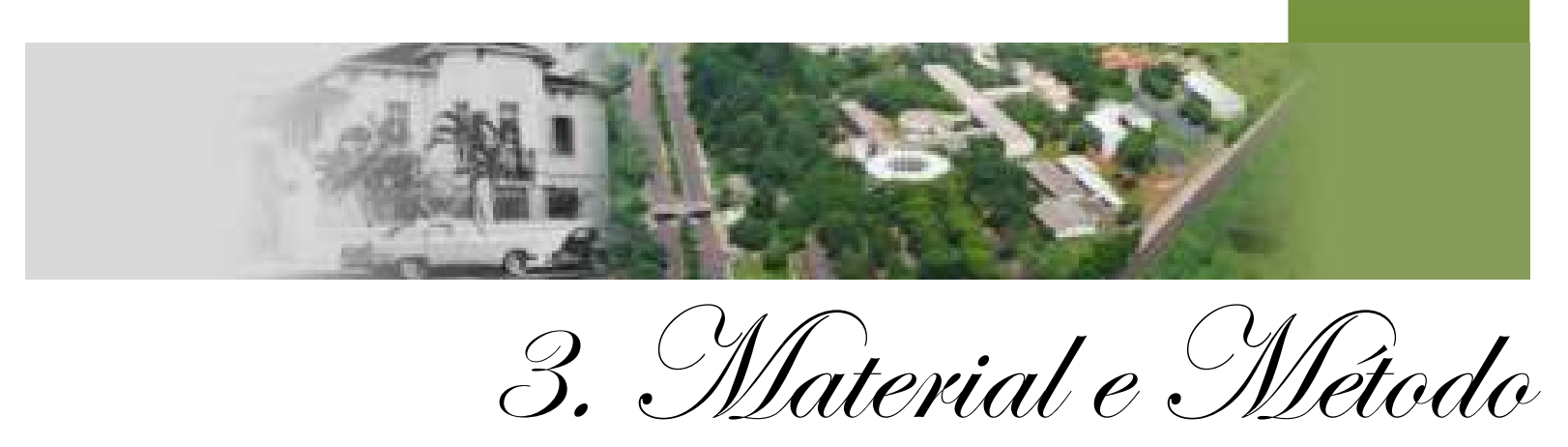





\section{MATERIAL E MÉTODO}

\subsection{Material}

\subsubsection{Amostragem (Seleção dos Animais)}

Foi usado para este experimento um total de 70 ratos da linhagem Wistar (Rattus norvegicus, albinus) machos com seis semanas de vida (jovens em desenvolvimento) pesando em média $180 \mathrm{~g}$. Os animais foram fornecidos pelo Biotério Central da Universidade de São Paulo - campus Ribeirão Preto. Este projeto teve a aprovação da Comissão de Ética no Uso de Animal (CEUA - USP) protocolo $\mathrm{n}^{0}$ 10.1.267.53.0. Durante todo o período experimental os animais foram alimentados com dieta padrão, constituída por ração moída (Labina - Purina) a fim de se evitar eventuais danos ao aparelho ortodôntico durante a mastigação; e água ad libitum.

\subsubsection{Delineamento Experimental}

Para cada período experimental foram utilizados cinco animais $(n=5)$, sendo as distribuições aleatórias dos animais, nos Grupos Controle e Experimentais, da seguinte forma:

Grupo Controle Negativo $(n=10)$ : animais não tratados, sem expansão rápida da maxila (ERM) e sem aplicação do laser de baixa potência (LBP), sendo 5 animais usados para PCR e Western Blotting e 5 usados para os exames histológicos.

Grupo Experimental I $(n=30)$ : animais que tiveram ERM, submetidos à eutanásia 3, 7 e 10 dias após ERM, sendo 15 animais para PCR e Western Blotting e 15 para exames histológicos. 
Grupo Experimental II $(n=30)$ : animais que tiveram ERM + LBP nos primeiros três dias do experimento $\left(3 X 160\right.$ total $\left.=480 \mathrm{~J} / \mathrm{cm}^{2}\right)$, submetidos à eutanásia nos períodos 3, 7 e 10 dias após ERM, sendo 15 animais para PCR e Western Blotting, e 15 animais usados para o exame histológico.

\begin{tabular}{|l|c|c|}
\hline \multicolumn{3}{|c|}{ RATOS JOVENS (6 SEMANAS DE VIDA) } \\
\hline Controle & Disjunção & Disjunção + laser \\
\hline & 03 dias & 03 dias * (160J) \\
\hline & 07 dias & 07 dias * $^{*}(160 \mathrm{~J})$ \\
\hline & 10 dias & 10 dias * $^{*}(160 \mathrm{~J})$ \\
\hline
\end{tabular}

* aplicações de laser, sendo que no grupo experimental II foi feita uma única aplicação e no Grupo Experimental III três aplicaçoes, sendo uma aplicação a cada dia, nos 3 primeiros dias, totalizando 480 $\mathrm{J} / \mathrm{cm}^{2}$.

Quadro 1 - Distribuição da amostra de acordo com os períodos de exprimento e irradiação com laser

\subsection{Método}

\subsubsection{Anestesia dos Animais}

Todos os procedimentos nos animais foram realizados sob sedação com Ketamina (anestésico Ketamina Agener) e Xylazina (relaxante muscular Dopaser) numa proporção 1:2 respectivamente $(1 \mathrm{mg} / \mathrm{kg})$ por via intramuscular.

\subsubsection{Instalação e Ativação do Dispositivo Ortodôntico para a Disjunção da Sutura Palatina Mediana}

O mecanismo de força utilizado era constituído de um grampo passivo de $1,5 \mathrm{~mm}$ de largura, confeccionada com fio de aço inoxidável de 0,5mm de diâmetro (Morelli $^{\circledR}$, Sorocaba, Brasil), colocada entre os incisivos superiores (Figura 1; página 37), semelhante ao apresentado na literatura (SAITO; SHIMIZU, 1997; SAWADA; SHIMIZU, 1996) com o intuito de possibilitar a correta calibração e padronização da força empregada em todos os animais e permitir manter a disjunção da sutura palatina mediana. Todos os ratos dos Grupos Experimentais foram submetidos à disjunção da sutura palatina.

Na montagem do dispositivo para disjunção foram utilizados alicates $n^{0} 139$, alicate para corte de fio espesso (Dentaurum ${ }^{\circledR}$ ), espelho bucal (Duflex ${ }^{\circledR}$ ), sonda 
exploradora $n^{0} 5$ (Duflex ${ }^{\circledR}$ ) e calcador de anéis (Duflex ${ }^{\circledR}$ ). Todos os dispositivos ortodônticos foram confeccionados e instalados pelo mesmo operador e assistente, seguindo sempre o mesmo protocolo.

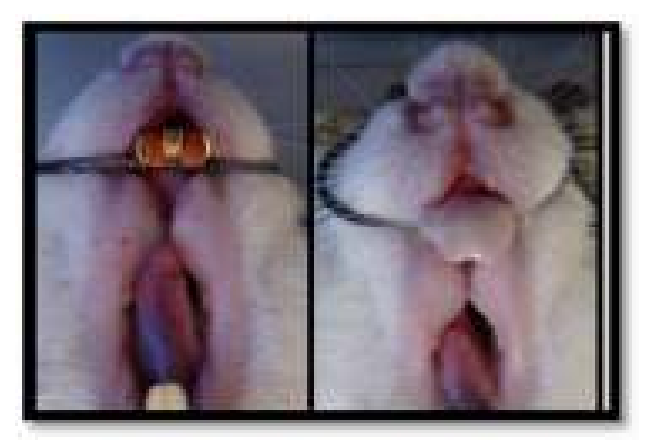

Figura 1 - Vista oclusal mostrando a mola utilizada para a ERM colocada entre os incisivos centrais

Previamente a montagem do dispositivo para a disjunção maxilar foi preparada a superfície dos incisivos para aumentar a retenção e estabilizar a mola a ser confeccionada para inseri-la entre os incisivos superiores. Foi utilizada uma broca esférica diamantada nำ1011 (K.G. Sorensen) em motor de alta rotação (DabiAtlante) para confeccionar sulcos rasos, apenas no esmalte, no terço gengival das faces vestibular e distal dos incisivos superiores. Em seguida foi realizada profilaxia dos incisivos com pasta de pedra-pomes misturada com água aplicada em taça de borracha $\left(\right.$ Viking ${ }^{\circledR}$ ) em contra-ângulo adaptado ao micromotor (Dabi- Atlante ${ }^{\circledR}$ ) por 15 segundos. Realizou-se a lavagem com spray (água-ar) e a secagem com ar proveniente da seringa tríplice e condicionamento do esmalte nos incisivos utilizando ácido ortofosfórico a $37 \%$ em forma de gel $\left(3 \mathrm{M}^{\circledR}\right)$, durante 60 segundos, conforme recomendações do fabricante. Na sequência foi feita, novamente, a lavagem e secagem das superfícies dentárias, por 15 segundos, com o auxílio da seringa tríplice. O agente de união (Primer e Bond 2.0 - Dentsply ${ }^{\circledR}$ ) foi aplicado sobre a superfície condicionada do esmalte e fotopolimerizado com luz halógena por 20 segundos com auxílio do aparelho Heliomat II $\left(\right.$ Vigodent $\left.^{\circledR}\right)$. A resina fotopolimerizável $\left(\right.$ Transbond-ETM ${ }^{\circledR}$ ) foi adaptada sobre o segmento de fio nas faces vestibular e distal recobrindo-o e, em seguida foi induzida a polimerização por meio de luz halógena, 
com comprimento de onda de $470 \eta \mathrm{m}$ (Heliomat II, Vigodent ${ }^{\circledR}$ ), durante 30 segundos, dirigida em orientação oclusal, vestibular, mesial e distal de cada incisivo. Para compensar o desgaste decorrente do contínuo hábito roedor dos animais, várias camadas de resina foram fotopolimerizadas sobre o grampo. Após a ativação inicial, o aparelho não recebeu outra ativação adicional durante o experimento e seu correto posicionamento foi conferido diariamente, quanto à posição, à estabilidade e à necessidade de correções na eventualidade de estar causando injúrias à mucosa oral do animal.

A espessura da mola foi determinada com base em resultados de um estudo preliminar (SAWADA; SHIMIZU, 1996) que indicou que 1,5mm de disjunção entre os incisivos induz a taxa máxima de separação na sutura palatina mediana sem diminuição contínua do peso corpóreo do animal. Todos os procedimentos operatórios foram realizados na sala de Cirurgia Experimental do Biotério da Faculdade de Odontologia de Ribeirão Preto - FORP/USP, em condições de higiene adequadas e, pelos mesmos operadores.

\subsubsection{Procedimento de Irradiação com Laser}

Como fonte de laser de baixa-potência, um dispositivo de laser de diodo de alumínio-gálio-arsenieto (Al-Ga-As) $\left(\mathrm{DMC}^{\circledR}\right.$ - São Carlos - SP) foi usado. As especificações técnicas deste dispositivo de laser são como segue: variáveis comprimento de onda: $830 \eta \mathrm{m}$ (invisível e estando na faixa do infravermelho próximo); aplicação pontual; $100 \mathrm{~mW}$ de potência e a densidade de energia utilizada foram de $160 \mathrm{~J} / \mathrm{cm}^{2}$ baseada em experimentos anteriores (TAKEDA, 1988; ORIKASA; SHIMAKURA; KUSAKARI, 1989; NAGASAWA; KATO; NEGISHI, 1991). No caso do feixe de laser, a grandeza é a energia luminosa (medida em Joules) e a área é aquela abrangida pelo ângulo sólido formado pelo feixe sobre a superfície de aplicação (medida em $\mathrm{mm}^{2}$ ), que nesse aparelho de aplicação pontual, é fixa $\left(0,00785 \mathrm{~mm}^{2}\right)$. Essa dosagem $\left(\mathrm{J} / \mathrm{cm}^{2}\right)$ foi aplicada calculando-se o tempo (s) necessário numa determinada potência $(\mathrm{mW})$ de $100 \mathrm{~mW}$, onde: $\mathrm{D}=P x T / A$. 


\begin{tabular}{|l|l|}
\hline Parâmetros de irradiação & Valores \\
\hline Densidade de Energia (DE) & $160 \mathrm{~J} / \mathrm{cm}^{2}$ \\
\hline Potência & $100 \mathrm{~mW}$ \\
\hline Comprimento de onda & $830 \eta \mathrm{m}$ \\
\hline Côr & Invisível (IV) \\
\hline Regime de emissão & Contínuo \\
\hline Área de abrangência & $0,00785 \mathrm{~mm}^{2}$ \\
\hline Distância da mucosa & Em contato/método pontual \\
\hline Tempo & 42 segundos/ponto único de aplicação \\
\hline
\end{tabular}

Quadro 2 - Protocololo de irradiação utilizado

A ponta do laser é composta por uma fibra óptica $0,6 \mathrm{~mm}$ de diâmetro cuja área de irradiação corresponde a $0,00785 \mathrm{~mm}^{2}$, e a irradiação foi aplicada sob anestesia, colocando a extremidade da ponta da fibra óptica em contato com a mucosa palatal na linha média e o ponto mediano entre as extremidades anteriores dos incisivos e papila incisiva (Figura 2, página 39).

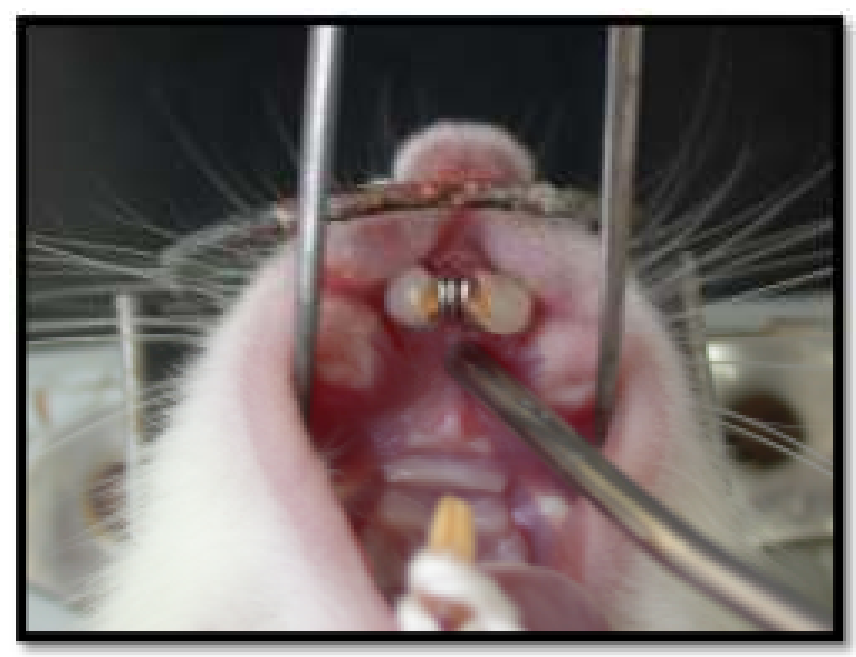

Figura 2 - Vista oclusal durante irradiação de laser na sutura palatina mediana, com o dispositivo ortodôntico entre os incisivos centrais 


\subsubsection{Eutanásia dos Animais, coleta e preparo dos espécimes}

Os procedimentos operatórios foram realizados na sala de cirurgia experimental do Biotério I da FORP-USP, em condições de limpeza, anti-sepsia e desinfecção, com instrumentos esterilizados em autoclave. Ao término dos períodos experimentais, os animais sofreram eutanásia por uma injeção com sobredose de anestésico com Ketamina e Xilazina via intramuscular e, em seguida, foram decapitados.

A metodologia deste trabalho foi desenvolvida em três etapas: Análise Histológica, RT-PCR em tempo real e Western Blotting. As peças foram cuidadosamente coletadas e subdivididas conforme o tipo de análise a ser realizada posteriormente.

Parte da amostra que seria destinada a exames histológicos foi conservada em paraformaldeído tamponado a $10 \%$ e a outra metade, destinada ao RT-PCR e Western Blotting, foi dissecada logo após a eutanásia e imediatamente conservada no freezer à $-80^{\circ} \mathrm{C}$.

Nos grupos para análise histológica, a maxila de cada animal foi removida, dissecada, seccionada mantendo a sutura palatina mediana. Fixou-se em solução de paraformaldeído tamponado a 10\%, com tampão fosfato $(\mathrm{pH} 7,2-7,4)$ por 48 horas. Os cortes histológicos para a realização da análise microscópica foram obtidos com $5 \mu \mathrm{m}$ de espessura, em micrótomo rotatório, de acordo com a rotina do Laboratório de Morfologia da FORP-USP.

Imediatamente após a eutanásia dos animais, nos grupos para extração de RNA, o tecido ósseo ao redor da sutura palatina mediana foi removido, dissecado e armazenado em tubos "eppendorf" contendo RNAlater ${ }^{\circledR}$ (Ambion Inc., Austin, TX, USA) para a preservação da integridade do RNA, permitindo assim o transporte posterior e acondicionamento das amostras em freezer $-80^{\circ} \mathrm{C}$, até o momento da extração de RNA total, para a realização do PCR e Western blotting que será descrito posteriormente.

Cinco animais por período foram aleatoriamente utilizados para obtenção dos espécimes para cada uma das técnicas estudadas. Portanto, parte da amostra foi destinada Western blotting e a outra parte para a microscopia óptica corados com hematoxilina-eosina (HE) e Tricrômico de Masson. 


\subsubsection{Metodologias para Avaliar a Vascularização e a Expressão Gênica do VEFG após a ERM}

\subsubsection{Processamento Histológico}

Após a eutanásia as peças foram mantidas em solução de Paraformaldeído (PFA 10\%) a $4^{\circ} \mathrm{C}$ por 48 horas para completar a fixação. Após este período as peças foram lavadas em solução tampão de Fosfato 0,1M e salina a 0,9\% (PBS) por 30 minutos. Em seguida, foram colocadas em solução desmineralizadora de etilenodiamino-tetracetato-dissódico a 10\%, 0.25M e pH=7,0 (EDTA - Labormax Produtos Químicos e Indústria), sob agitação constante à temperatura de 2 a $8^{\circ} \mathrm{C}$. A solução foi trocada a cada dois dias até a amostra ser completamente descalcificada. Ao final desse período, o osso já descalcificado foi desidratado em concentrações crescentes de álcool (Merck KGaA, Darmstadt, Alemanha), diafanizado em xilol (Merck KGaA, Darmstadt, Alemanha) e incluído em parafina de baixa fusão (Dinâmica Química Contemporânea, Brasil). Secções longitudinais semisseriadas com $5 \mu \mathrm{m}$ de espessura foram obtidas no sentido coronal (ântero-posterior) e longitudinal (infero-superior) e montadas em lâminas silanizadas (Dako Cytomation North America Inc, Carpinteria, CA, EUA). As lâminas destinadas à análise histológica foram coradas com Tricrômio de Masson e Hematoxilina e Eosina (H/E). O corte mais central de cada peça foi selecionado e serviu também como guia para a escolha dos outros cortes, assim, dois cortes diretamente antes e dois cortes diretamente depois foram selecionados para a análise imunostoquímica para VEGF). A montagem das lâminas se fez com lamínulas de vidro em "permount" (Fischer, USA), para o exame microscópico de rotina. Após secagem, as lâminas com os respectivos cortes corados, foram acondicionadas em caixas apropriadas e armazenadas em ambiente seco e fresco. Os parâmetros foram histometricamente analisados ao 3, 7 e 10 dias.

O objetivo da análise histológica foi investigar os eventos morfológicos que ocorreram na interface entre sutura palatina mediana e borda óssea, focando na presença de remodelação óssea e vascularização. A vitalidade do tecido sutural foi observada por meio da análise microscópica com auxílio do microscópio de transmissão de luz e considerou-se como critério de avaliação qualitativa a observação de tecido conjuntivo com presença de camada de osteoblastos delimitando as bordas ósseas, com vasos sanguíneos, fibroblastos e outros tipos 
celulares na porção central desse tecido, áreas de fibras colágenas, presença ou não de processo inflamatório, formação e organização do tecido conjuntivo, ósseo e medular, e remodelação óssea.

\subsubsection{Análise da Expressão Gênica}

A técnica de RT-PCR combina a síntese de CDNA, a partir de moldes de RNA, com PCR para fornecer um método rápido e específico para análise da expressão gênica. O RT-PCR em tempo real é usado para detectar e semiquantificar a expressão da mensagem, de pequenas quantidades de RNA (BUSTIN, 2000). No presente estudo, o controle positivo para VEGF, foi realizado com o gene constitutivo, gliceraldeido-3-fosfato desidrogenase (GAPDH).

\subsection{Extração, Isolamento e Avaliação do RNA total}

A solução de RNAlater foi aspirada e as peças ósseas ainda congeladas foram adicionadas em solução de lise. O RNAt foi extraído da maxila dos animais (50-100mg) usando o Sistema de extração de RNA total SV (Promega, Madison, $\mathrm{WI}$ ), de acordo com o protocolo sugerido pelo fabricante. Para isso as amostras de tecido ósseo foram inicialmente maceradas, pulverizadas em grau com pistilo contendo nitrogênio líquido. A seguir os tecidos foram imersos em reagente Trizol (Invitrogen-Life Technologies, Carlsbad/CA, EUA), seguindo o protocolo recomendado pelo fabricante, na proporção de $1 \mathrm{~mL}$ de Trizol para cada $1 \mathrm{mg}$ de tecido, sendo agitado por 30 segundos e mantidos a temperatura ambiente por 5 minutos. As amostras foram homogeneizadas em agitador de tubos (vortex), seguidas da adição de $0,2 \mathrm{~mL}$ de clorofórmio para cada $\mathrm{mL}$ de suspensão e centrifugadas a $12.000 \times \mathrm{g}$ por 15 minutos, a $4^{\circ} \mathrm{C}$, com formação de duas fases. $\mathrm{A}$ fase aquosa (superior) foi transferida para um tubo novo, ao qual foi adicionado o mesmo volume de isopropanol, sofrendo agitação em vortex e incubado por 20 minutos a $4^{\circ} \mathrm{C}$ para precipitar o RNA da fase aquosa. Para permitir a secagem das amostras, o sobrenadante foi descartado e os tubos foram deixados abertos em temperatura ambiente por 5 minutos dentro de uma capela de fluxo laminar vertical para impedir a contaminação das amostras. As amostras de RNA foram resuspensas em $50 \mu \mathrm{L}$ de água deionizada estéril tratada com dietilpirocarbonato 
(DEPC) e livre de RNAse, incubadas por 10 minutos a $56^{\circ} \mathrm{C}$, e armazenado no freezer a $-80^{\circ} \mathrm{C}$ para posterior análise.

Posteriormente, a quantidade e a pureza do RNA foram determinadas por espectrofotômetro Nanodrop (ND 100, Nanodrop Techonologies, USA) nos comprimentos de onda de 260nm e da relação entre absorbâncias a A260/A280nm, respectivamente. A relação A260/A280 foi considerada aceitável se estivesse entre 1.8 e 2.0, pois valores nesse intervalo indicam ausência de DNA na amostra (SAMBROOK; RUSSEL, 2001).

\subsection{Analise da Expressão do mRNA pela PCR em Tempo Real}

Os produtos da transcrição reversa RT-PCR serviram de molde para a amplificação e as reações de PCR foram analisados em tempo real, utilizando o kit TaqMan Gene Expression Assays (Applied Biosystems, Foster City, California) para o seguinte gene alvos VEGF (Rn 01511604-m1 101pb). O controle endogeno TaqMan (Applied Biosystems) para o gene GAPDH (X02231 437bp) (gliceraldeido-3fosfato desidrogenase) foi usado como gene de referência para a normalização dos valores (BUSTIN, 2000) .

Primeiramente, o RNA total foi tratado para a eliminação de qualquer resíduo de DNA na amostra (DNA-free ${ }^{\mathrm{TM}}$, Ambkm Inc., Austin, TX, USA) e posteriormente utilizado para a síntese de cDNA, onde $1 \mu \mathrm{g}$ da amostra (RNA) foi utilizado para a síntese do DNA complementar. A síntese do cDNA foi obtida a partir do RNA total, por reação de transcrição reversa, com a utilização $1 \mu \mathrm{L}$ de transcriptase reversa (High Capacity cDNA Reverse Transcription Kit, Applied BioSystems) em presença de $1 \mu \mathrm{L}$ de inibidor de RNAse (Appied BioSystems). A ordem e etapas de incubação foram realizadas de acordo com as recomendações de tempo e temperatura do fabricante dos reagentes, onde cDNA foi sintetizado utilizando o Eppendorf Mastercycler Gradient (Eppendorf, Milan, Italy) a $25^{\circ} \mathrm{C}$ por 10 minutos, $37^{\circ} \mathrm{C}$ por 120 minutos e $85^{\circ} \mathrm{C}$ por 5 minutos. Os cDNAs obtidos foram armazenados a $-20^{\circ} \mathrm{C}$ até a realização do RT-PCR.

O perfil das reações foi determinado seguindo as recomendações do fabricante do equipamento. As amplificações por PCR foram realizadas em 
quadriplicatas utilizando 50ng de cDNA por reação, e a água deionizada foi usada como controle negativo. As reações foram preparadas com reagentes padronizados para PCR em tempo real (TaqMan Universal PCR Master Mix, Applied Biosystem) adicionado dos conjuntos de primers e sonda específico para cada primer.

As condições de ciclagem térmica consistiu de um ciclo inicial a $50^{\circ} \mathrm{C}(2$ minutos), desnaturação a $95^{\circ} \mathrm{C}$ (10 minutos) e 40 repetições (ciclos de amplificação) a $95^{\circ} \mathrm{C}$ (15 segundos) e a $60^{\circ} \mathrm{C}$ (1 minuto), seguido de curva de dissociação padrão no sistema de detecção CFX 96 Real-time PCR (Bio-rad,California, EUA). Cada ciclo consistiu das fases de desnaturação, anelamento e extensão, sendo o tempo e temperatura de cada fase padronizada, de acordo com os primers utilizados. Para cada par de primers foi realizada PCR em água esterilizada para avaliação de possível contaminação dos primers (controle negativo água).

Para análise do RNAm, a expressão relativa do gene foi calculada em referência a expressão do GAPDH usando o método $\mathrm{C}_{\mathrm{T}}$ (Threshold Cycle $-2^{-\triangle \triangle C T}$ ). $\mathrm{O}$ método $\mathrm{C}_{\mathrm{T}}$ que se refere ao número de ciclos de PCR necessários para que o sinal fluorescente atinja o limiar de detecção. Os resultados individuais expressos em valores de $\mathrm{C}_{\mathrm{T}}$ foram a seguir transferidos para planilhas e agrupados de acordo com o grupo animal (laser e não-laser) e período experimental, para a realização da análise estatística.

\subsubsection{Expressão das Proteinas}

\subsection{Western Blotting}

O Western Blotting é um método altamente específico para detectar proteínas em um homogenato de células trituradas ou extraído de tecido biológico. Essa técnica usa eletroforese em gel para separar, após desnaturação, proteínas com pesos moleculares diferentes. As proteínas são transferidas do gel para uma membrana de nitrocelulose, sobre a qual será usado como sonda, anticorpo primário específico, contra a proteína de interesse e anticorpo secundário biotinilado associado peroxidase. A detecção do sinal é obtida com adição de um substrato quimioluminescente para esta peroxidase, sendo realizada revelação radiográfica para visualização das bandas. Nos resultados encontrados neste estudo foi avaliada a expressão de VEGF nas amostras, que foi comparada entre grupos e períodos. 
Para a análise quantitativa dessas proteínas por westem blotting foram utilizadas amostras coletadas de 5 animais por grupo e período, congeladas a $-80^{\circ} \mathrm{C}$.

\subsection{3.1.1 Extração e quantificação de proteína total}

Para extração da proteína total, o tecido ósseo de cada grupo animal, foi macerado em um graal e pistilo de porcelana autoclavado. Posteriormente foram coletadas em $1 \mathrm{ml}$ de PBS e centrifugadas a $10.000 \mathrm{~g}$, durante 10 minutos a $4^{\circ} \mathrm{C}$, para obtenção do pellet Em seguida, o sobrenadante foi descartado e o pellet resuspenso em $100 \mu \mathrm{l}$ de solução tampão Ripa (Ripa buffer; Pierce Biotechnology, Rockford, EUA), contendo inibidores de proteases (Complete Protease Inhibitor Cocktail, Roche Applied Science, Mannheim, Alemanha) e inibidores de fosfatases (PhosphoStop, Roche Applied Science). Os tubos foram mantidos em gelo por 20 minutos, centrifugados a $10.000 \mathrm{~g}$ durante 10 minutos a $4^{\circ} \mathrm{C}$ e o sobrenadante transferido para um novo tubo. Posteriormente para a quantificação da proteína total dos extratos protêicos, a partir do material removido da sutura palatina mediana foi realizado por meio do método de Bradford (BRADFORD, 1976). Para isto, foram

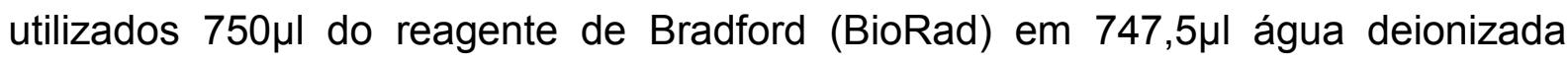
$(1500 \mu \mathrm{l})$, descontando-se $2,5 \mu \mathrm{l}$ para a amostra protêica, e uma solução de branco (de solução de Bradford, água deionizada e tampão de lise), em luz visível de comprimento de onda de $595 \eta \mathrm{m}$ foi usada para calibrar o espectrofotômetro (Spectronic). Os valores da absorbância das amostras foram aplicados ao gráfico da curva de Bradford, feito em planilha eletrônica (Excel) a partir das leituras da solução padrão de albumina sérica bovina (BSA - Sigma) nas concentrações de 1,0 a $10 \mu \mathrm{g} / \mu \mathrm{l}$, realizadas no mesmo procedimento. A leitura foi realizada em triplicata.

\subsection{Preparo das amostras}

Cinquenta $\mu \mathrm{g}$ de proteína total foram adicionados ao tampão de carregamento contendo $\beta$-Mercaptoetanol, na proporção de 1:4 e submetidos à desnaturação a $95^{\circ} \mathrm{C}$ por 5 minutos. Foram utilizados para realização do tampão os seguintes componentes, $20 \%$ Glicerol: densidade; $10 \%$ de BME (betamercaptoetanol) para efetuar quebra das pontes de dissutfeto desfazendo a 
estrutura quaternária, com isto, expondo os epítopos aonde o anticorpo irá se ligar; mais 4\% SDS (Dodecil Sulfato de Sódio, Bio-Rad Laboratories, Califórnia - USA) deixando as proteínas da amostra carregadas negativamente para que possam correr mais facilmente no gel; e por fim 0,004\% Azul de Bromofenol, um corante, que facilita a visualização da corrida.

\subsection{Corrida das proteínas no gel de poliacrilamida e transferência das proteínas para a membrana de nitrocelulose}

a) Foram utilizados $50 \mu \mathrm{g}$ de proteína total de cada amostra e as mesmas foram eletroforeticamente separadas por tamanho, usando-se sistema de gel de poliacrilamida de 10 a $15 \%$, dependendo do peso molecular da proteína de interesse, pelo sistema SDS-PAGE. O marcador do peso molecular utilizado foi o Kaleidoscope (Bio-Rad Kaleidoscope Prestained Standards cod. 161-0324 - Control 310001228, Bio-Rad Laboratories, Calífomia - USA) aplicado no respectivo gel.

b) A corrida foi iniciada com 200 Volts (constante) até passar o gel de largada. Em seguida, foi mantida a amperagem (constante) de $150 \mathrm{~V}$ até o final da corrida (aproximadamente 1:30 horas).

c) Após a separação das proteínas de acordo com o peso molecular, as mesmas foram eletroforeticamente transferidas para membranas de nitrocelulose utilizando solução-tampão de transferência em um aparato de transferência úmida. Para isso utilizou-se o kit para transferência imerso no tampão de transferência\# onde foi feito um "sanduíche" contendo: esponja + papel de filtro + gel + membrana de nitrocelulose + papel de filtro + esponja. Em seguida, foi transferido para cuba e coberto com o tampão de transferênciä (6,05g de Tris; 2,82g de Glicina; $400 \mathrm{~mL}$ de Metanol e $0,4 \mathrm{~g}$ de SDS, completando com água deionizada até $2 \mathrm{~L}$ ). A transferência foi realizada em 100 volts com amperagem constante por 1 hora. 


\subsection{Imunomarcação e a evidenciação das proteínas na membrana de nitrocelulose}

Para a imunomarcação e a evidenciacão das proteínas na membrana de nitrocelulose foram realizados os seguintes procedimentos:

a) Após a transferência, das proteínas para as membranas de nitrocelulose, a membrana foi colocada em solução de Ponceau Red para verificar o aparecimento das bandas e se a transferência ocorreu satisfatóriamente.

b) Em seguida os sítios de ligação não-específica foram bloqueados. Para isso a membrana foi incubada em solução salina tamponada com Tris (TBS; StartingBlock ${ }^{\text {TM }}$ TBS Blocking Buffer; Pierce Biotechnology, Rockford, EUA) contendo albumina de soro bovino a $5 \%$, por 1 hora, sob constante agitação, em temperatura ambiente.

c) Posteriormente, a solução de bloqueio foi removida lavando a membrana com solução basal (TBST) por 5 minutos $(3 \times)$, para a retirada do excesso de albumina e as mesmas foram incubadas no anticorpo primário específico (Santa Cruz Biotechnology, Santa Cruz, CA, U.S.A) para VEGF (SC-7269) e GAPDH (SC25778) diluídas no diluente para anticorpo em $10 \mathrm{~mL}$ de solução Basal + 0,3g BSA (albumina) na concentração de 1:200, sob agitação constante, overnight, em temperatura de $4^{\circ} \mathrm{C}$. Os anticorpos foram previamente titulados com o objetivo de determinar as concentrações e tempo de incubação adequado, para cada um.

d) No dia seguinte, as membranas foram lavadas na solução basal (TBST) por 5 minutos $(3 \mathrm{x})$, para a retirada do excesso de anticorpo primário e a seguir foram incubadas com anticorpos secundários contra imunoglobulina $G$ (lgG) de cabra, camundongo ou coelho conjugados à horseradish peroxidase (Santa Cruz Biotechnology), por 30 minutos, sob agitação, à temperatura ambiente, diluídos em 1:10.000 no diluente para anticorpo.

e) A seguir, as membranas foram lavadas em TBST por 5 minutos $(4 \times)$. As bandas foram evidenciadas por quimioluminescência utilizando o sistema de detecção West-Pico Enhanced Chemoluminescence (ECL; Pierce Biotechnology), por 5 minutos, seguido pela exposição em filmes radiográficos. As bandas géis foram fotografadas com uma câmara digital (Sony) sobre negatoscópio (VH Equipamentos, Araraquara, Brasil). 
Portanto, para análise quantitativa por densitometria foi usado como parâmetro de comparação os valores de intensidade obtidos para banda GAPDH. As imagens obtidas das bandas da proteína Vegf e de todos os grupos estudados foram comparadas através da análise densitométrica (em função dos pixels e da área da banda). Para isso todas as imagens da chapa fotográfica foram capturadas com $300 d p i$ de resolução usando máquina fotográfica digital (Sony) e transferidas para o software IMAGE J 1.28u (programa de domínio público desenvolvido por Wayne Rasband NIMH, NIH, USA), onde foram feitas as quantificações por densitometria. Para cada amostra foi obtida uma relação entre a intensidade da banda alvo (VEGF) e a banda de GAPDH no gel de agarose. Os dados obtidos foram submetidos à normalização e os resultados foram apresentados em forma de porcentagem (expressão relativa), mostrando o valor que cada banda ocupa em relação à área selecionada.

\subsection{Análise histométrica}

Para a realização da análise histomorfométrica, foi utilizado o método "estereológico" ou "casualização de amostra" que consiste em determinar parâmetros quantitativos tridimensionais de estruturas anatômicas a partir de cortes histológicos, com intuito de eliminar a ocorrência de vício na amostragem. O referido método baseia-se no princípio geométrico-estatístico, derivados da probabilidade das imagens e dos perfis da estrutura no corte histológico, resultando num sistemateste efetivo. Portanto, realizaram-se os procedimentos de escolhas aleatórias para as seguintes fases do experimento: seleção dos animais, dos blocos histológicos, das lâminas histológicas, dos cortes e campos histológicos.

Todas as medidas foram realizadas por um mesmo pesquisador que desconhecia os grupos experimentais e os tratamentos realizados. O pesquisador foi submetido a um rigoroso processo de calibração pela repetição de mensurações, em um intervalo de 48 horas, utilizando $10 \%$ do total das imagens digitais, selecionadas aleatoriamente. A calibração foi aceita se a concordância existente entre as medidas iniciais e aquelas realizadas após 48 horas era maior ou igual a $90 \%$. 


\subsection{Análise histométrica do tecido inflamatório.}

Para os cortes corados por Hematoxilina e eosina (H/E) e Tricrômico de Masson (TM) foi realizada uma análise quantitativa do grau de processo inflamatório. Para a quantificação foi utilizadoo Software IMAGE J. A quantificação das ocorrências histomorfológicas foi baseada em critérios descritos na literatura (WOLFSON; SELTZER, 1975; HOLLAND et al., 2007), onde foram atribuídos escores de 1 a 4 aos diferentes eventos abaixo listados (Quadro 3). Os eventos considerados para análise foram:

Intensidade do processo inflamatório:

\begin{tabular}{|c|l|}
\hline ESCORE & \multicolumn{1}{|c|}{ CARACTERIZAÇÃO } \\
\hline 1 & \begin{tabular}{l} 
Ausência ou presença ocasional de células inflamatórias \\
\hline 2
\end{tabular} \\
$\begin{array}{l}\text { Pequeno número de células inflamatórias, Até 10 células/campo (aumento de } \\
100 x)\end{array}$ \\
\hline 3 & $\begin{array}{l}\text { Moderado número de células inflamatórias. De } 11 \text { a } 50 \text { células/campo } \\
\text { (aumento de 100x); }\end{array}$ \\
\hline 4 & $\begin{array}{l}\text { Grande número de células inflamatórias. Acima de } 50 \text { células/campo } \\
\text { (aumento de 100X) }\end{array}$ \\
\hline
\end{tabular}

Adaptado de Wolfson and Seltzer (1975) e Holland et al (2007)

Quadro 3 - Escore de grau de inflamação

\subsubsection{Análise dos Resultados}

\subsubsection{Precisão da Metodologia (Calibração do examinador)}

Para a confiabilidade dos resultados desse trabalho, procurou-se minimizar os erros dos métodos de mensuração empregados. Calculou-se a precisão do investigador pelo erro sistemático intraexaminador. O erro sistemático reflete uma falta de padronização do método, uma vez que o examinador tende a sub ou superestimar os valores de suas medições de maneira inconsciente, de modo a direcionar os resultados de acordo com as expectativas em relação às conclusões do estudo. Para avaliar a calibração do examinador, nas medidas histológicas, foi realizada, previamente às leituras finais, a correlação intraclasse. Vinte cortes foram aleatoriamente selecionados e suas medições foram feitas e repetidas três semanas após a primeira medição. Assim, observou-se que erros na verificação da precisão desse estudo foram admissíveis, promovendo resultados fidedignos.

Para estimar o valor do erro intraexaminador sistemático do método, as 
amostras de RT-PCR e Western blotting foram novamente analisadas, 30 dias após a análise inicial. O teste $t$ pareado foi usado para analisar o erro intraexaminador sistemático do método, por meio da comparação dos valores das duas análises distintas com intervalo de 30 dias. Valores de $p<0,05$ foram considerados para estimar a viabilidade de utilização do método proposto. Assim, observou-se que erros na verificação da precisão desse estudo foram admissíveis, promovendo resultados fidedignos.

\subsubsection{Análise Estatística}

Os resultados do RT-PCR em tempo real, os valores da densidade óptica relativa das bandas imunorreativas e as medidas histológicas foram agrupados de acordo com o grupo animal (laser e não-laser) e período experimental, foram organizados em tabelas e submetidos à analise estatística.

Uma vez obtidos os dados, médias representativas de cada grupo foram submetidas a uma análise estatística com nível de significância de 5\%. Para a análise intragrupo (efeito do tempo) foi utilizado o teste paramétrico de análise de variância (One-Way ANOVA) e, quando detectada diferença estatisticamente significante, o teste paramétrico de Tukey foi utilizado para detectar a diferença entre os grupos dentro do mesmo ensaio.

A análise intergrupo (efeito do tratamento) testou a hipótese de que a aplicação do laser de baixa potência modifica a reparação óssea por meio da alteração do padrão de expressão gênica por meio do teste paramétrico de análise de variância (Two-Way ANOVA) e, quando detectada diferença estatisticamente significante, o teste paramétrico de Tukey $(p<0,05)$ foi aplicado. Para as medidas em escores os dados foram agrupados e apresentados em medianas, intervalos interquartil, e os valores mínimos (variáveis ordinais) e máximo. O teste KruskalWallis e os testes de Dunn $(p<0,05)$ foram utilizados para os escores. Todos os testes foram realizados com o programa de estatística GraphPad Prism versão 5 (GraphPad Software Inc., San Diego, CA), tendo sido adotado o nível de significância de $0,05(\alpha=5 \%)$ para que as diferenças fossem consideradas estatisticamente significativas. 


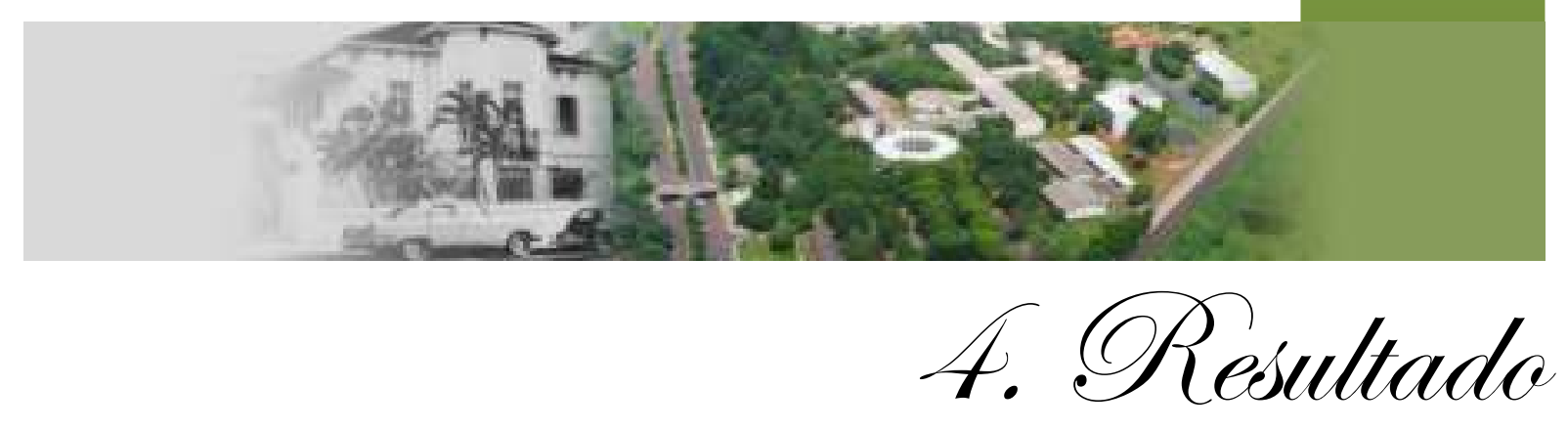





\section{RESULTADO}

\subsection{Análise Histológica}

Os resultados morfológicos dos cortes da sutura palatina mediana submetida à ERM e aplicação do LBP estão representados pelas Figura 3, página 55, à Figura 9 página 79 .

\section{a. Grupo controle (sutura normal) \\ O exame histológico da sutura palatina mediana dos animais do Grupo} Controle mostrou características de normalidade dessas estruturas que serviram como termo comparativo com os animais dos Grupos Experimentais.

A superfície óssea sutural apresentou-se regular e organizada e ao longo dessa superfície verificou-se osteoblasto em repouso e alguns osteoblastos ativos enfileirados geralmente de maneira organizada. $O$ tecido conjuntivo sutural caracterizou-se por ser fibroso rico em fibroblastos e fibras colágenas e com a presença de capilares em toda extensão do tecido sutural. Os fibroblastos caracterizaram-se por possuírem núcleo ovóide e claro, e nucléolo evidente. Os feixes de fibras colágenas eram espessos e perpendiculares ou oblíquos à superfície da sutura, inseridos no osso, e fibras com variadas orientações na porção mediana da sutura. Os vasos sangüíneos apresentaram-se com luz circular ou levemente ovaladas e com células sanguíneas, distribuídos principalmente a meia distância das bordas ósseas. O osso da pré-maxila revelou cavidades medulares e canais de Havers na metade lateral, sendo que na porção medial as trabéculas estavam paralelas à linha mediana separada por linhas de aposição óssea. Foi notada, também, a presença de numerosos osteócitos, no interior das lacunas (Figura 3, página 55). 


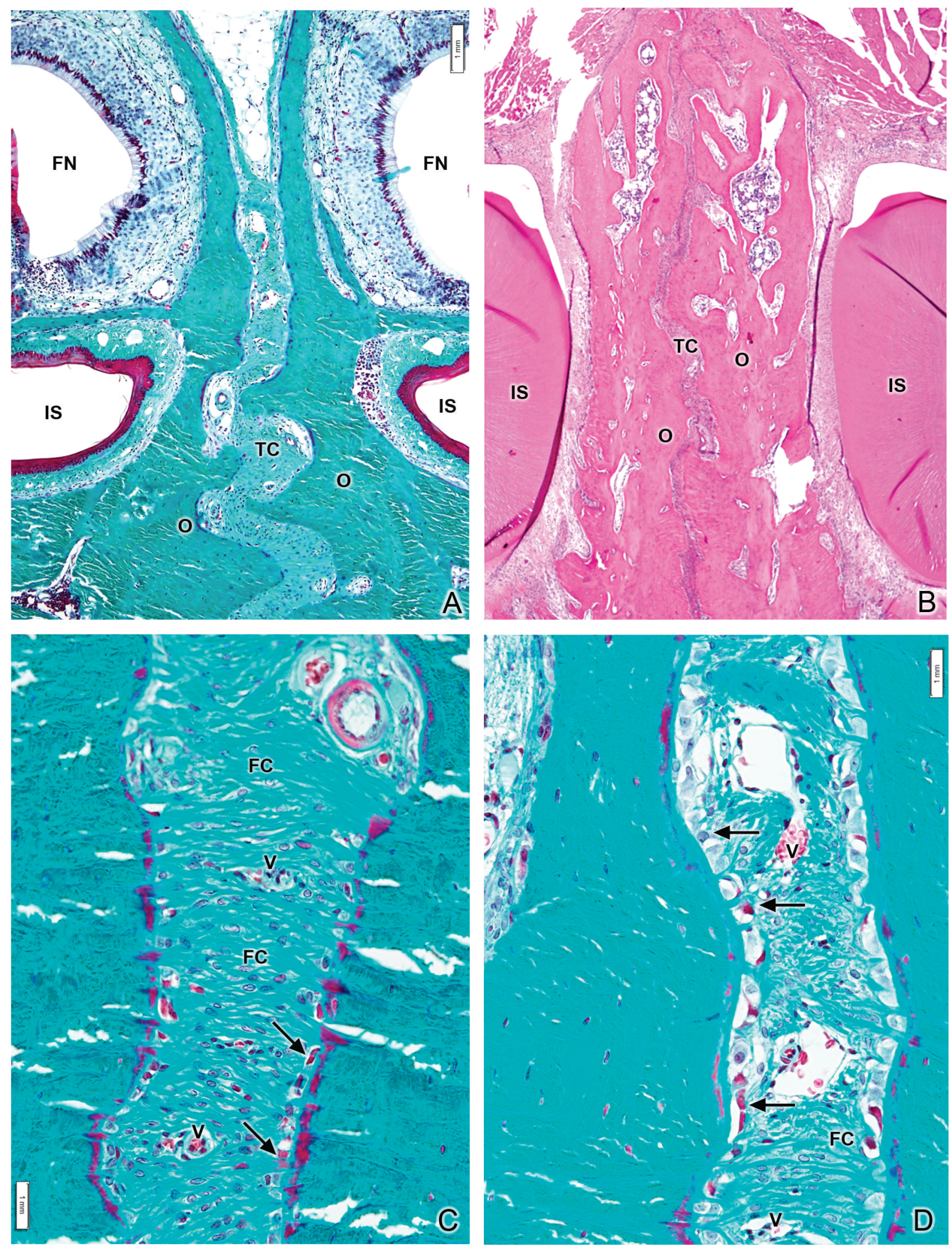

Figura 3 - Região da sutura palatina mediana do grupo controle. A) e B) visão panorâmica mostrando a sutura palatina mediana da porção cervical até a região nasal. $O$ tecido conjuntivo sutural (TC) está envolto por tecido ósseo (O) e delimitado pelas fossas nasais (FN) e pelas coroas dos incisivos superiores (IS). C) Detalhe da sutura onde é possível verificar osteoblastos (OB) delimitando a superfície óssea (setas pretas) e vasos sanguíneos (V) por toda extensão do tecido sutural e presença de fibras colágenas (FC) inseridas no tecido ósseo. 



\section{b. Grupo Experimental I (disjunção sem aplicação do laser)}

As estruturas da sutura palatina mediana revelaram modificações expressivas de seus componentes, em decorrência da força aplicada.

\section{b.1 Disjunção 3 dias}

Após 3 dias da ERM foi observado um afastamento das margens ósseas suturais das hemi-maxilas, e observou-se que houve rompimento do tecido sutural, e alguns fragmentos ficaram aderidos à margem sutural e outros, destacaram-se desta e foram circundados por neutrófilos. Notou-se ainda, muitas áreas "arroxeadas" devido à autólise das células, com os núcleos picnóticos. A presença de áreas hemorrágicas contendo neutrófilos, linfócitos, hemácias e monócitos foram predominantes neste período, em toda a extensão do tecido sutural. As células do tecido sutural, como os fibroblastos e osteoblastos mostravam-se alteradas com núcleo picnótico (contraídos e achatados). O fenômeno de lise celular também foi observado. Houve diminuição do número de células, perda de organização dos feixes de fibras colágenas e poucos vasos sangüíneos íntegros estavam presentes. Nesse período, apesar de não ser tão evidente, houve início da migração de células mononucleares (linfócitos e macrófagos), principalmente na borda lateral da parede óssea, onde ainda apresentava tecido conjuntivo aderido. Os vasos sanguíneos presentes estavam restritos às bordas ósseas (Figura 4, página 59). 


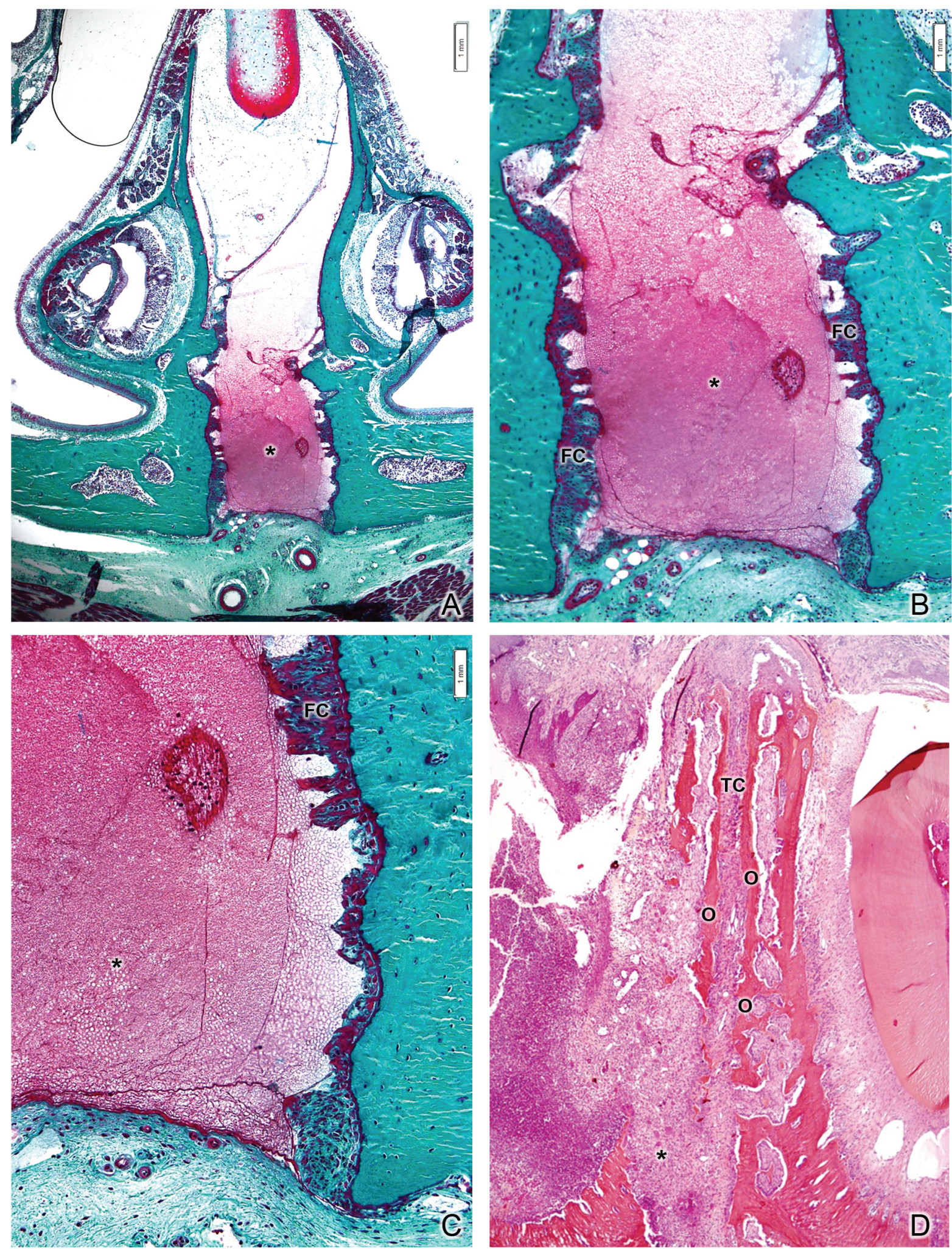

Figura 4 - Região da sutura palatina mediana do grupo Experimental I (3 dias). A) visão panorâmica mostrando a sutura palatina mediana onde observa intensa hemorragia (*). Em B) observa-se as fibras colágenas (FC) aderidas a parede óssea. C) Presença de fibras colágenas (FC) inseridas no tecido ósseo e área hemorrógica (*). D) Vista panorâmica onde observa-se as bordas ósseas da sutura palatina (O) delimitando o tecido conjuntivo (TC). 



\section{b. 2 Disjunção 7 dias}

Notou-se, no tecido sutural, grande proliferação vascular, com a presença de neutrófilos (polimorfornucleares) e grande número de mononucleares caracterizando ainda a presença de um infiltrado inflamatório, e, alguns fibroblastos íntegros, fibras colágenas desorganizadas. A presença de macrófagos também foi evidente (células de núcleo grande e claro; citoplasma grande e avermelhado). Algumas regiões revelam a presença de fibroblastos, inclusive, fibras colágenas em desenvolvimento. Quanto aos vasos sangüíneos estes eram numerosos sem a presença de tecido hialinizado, provavelmente, porque já foi fagocitado. Os ossos de sustentação do tecido sutural caracterizaram-se, nos dois terços superiores, por trabécula óssea remanescente delgada circundada por células inflamatórias. A superfície sutural do osso, continha células ativas onde foi observada reabsorção óssea frontal (osteoclastos na superfície óssea), e no lado oposto, em direção às cavidades medulares havia a presença de numerosos osteoclastos ativos, no interior das lacunas de Howship dentro das cavidades medulares, caracterizando uma intensa reabsorção óssea solapante. A proliferaçñao vascular foi mais evidente nas proximidades do tecido ósseo em direção à área central onde predominava o processo inflamatório (Figura 5, página 63). 


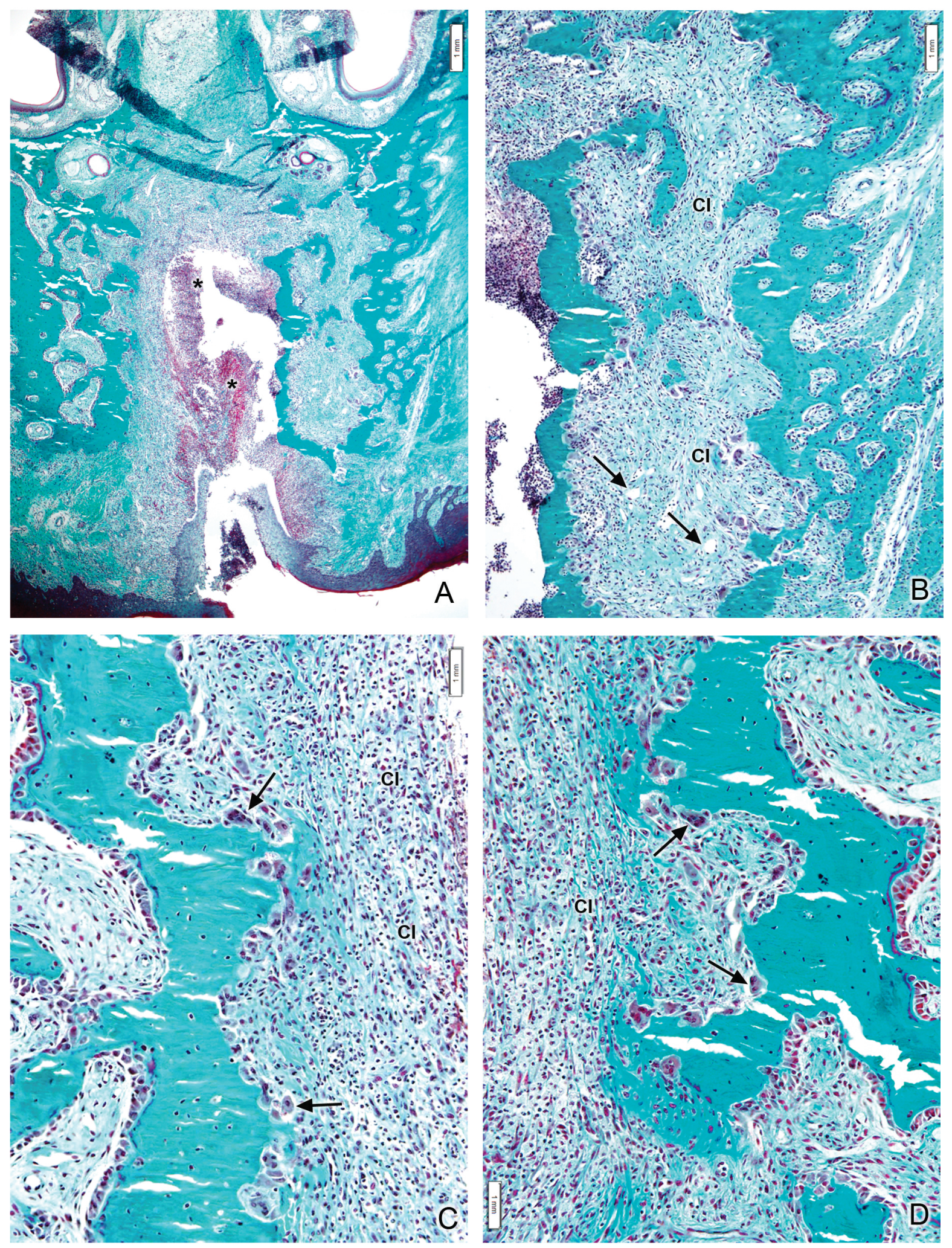

Figura 5 - Região da sutura palatina mediana do grupo Experimental I ( $7^{\circ}$ dia). A) visão panorâmica mostrando a sutura palatina mediana onde ainda observa área hemorragica $\left({ }^{*}\right)$. Em B) observa-se tecido conjuntivo com células inflamatórias (Cl) e vasos sanguíneos (setas brancas). C) e D) Presença de osteoclastos (OC) na superfície interna da sutura palatina (setas pretas) e células inflamatórias (Cl). 



\section{b.3 Disjunção 10 dias}

O espaço sutural estava ainda irregular. $O$ tecido sutural caracterizou-se por ser mais fibroso, com fibras colágenas desorganizadas, sendo que muitas não estavam contínuas em sua extensão, e algumas fibras estavam orientadas em sua inserção no osso (fibras de Sharpey). Muitos vasos sangüíneos, fibroblastos abundantes, e células grandes na superfície óssea, revelando atividade dos osteoblastos, e outros que pareciam osteoclastos devido à presença de áreas erosivas, foram evidenciados. As células em contato com a superfície óssea sutural irregular eram volumosas, representadas por osteoblastos e alguns osteoclastos. Os vasos sanguíneos estavam menos numerosos que o grupo anterior e se distribuinam principalmente próximos ao tecido ósseo (Figura 6, página 67). 


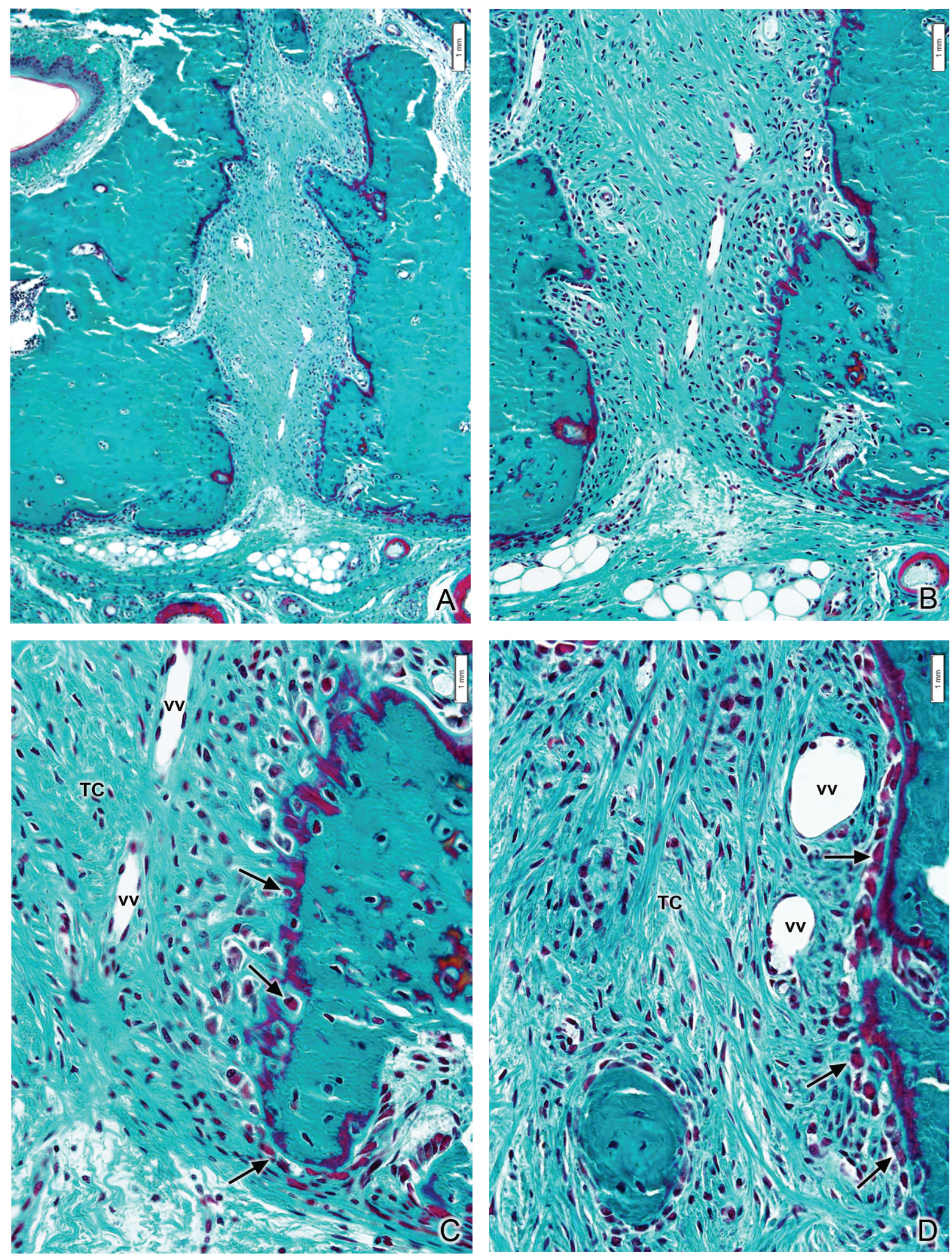

Figura 6 - Região da sutura palatina mediana do grupo Experimental I $\left(10^{\circ}\right.$ dia). A) visão panorâmica mostrando a sutura palatina mediana sem área hemorrágica. Em B) observa-se intensa proliferação de fibras colágenas. C) e D) Presença de osteoblastos revestindo o tecido ósseo (setas pretas) recém formado e fibroblastos distribuídos pelo tecido conjuntivo (TC) e vasos sanguíneos (VV). 



\section{c. Grupo Experimental II (disjunção com aplicação do laser)}

\section{c.1 Disjunção 3 dias + aplicação de laser}

O tecido sutural mostrou-se muito modificado, com mudanças substanciais em seus componentes em função do trauma provocado pelo rompimento da sutura palatina mediana. Notou-se um alargamento desse espaço, principalmente na região anterior da sutura. No terço anterior, as fibras colágenas estavam rompidas e desorganizadas principalmente próximas ao tecido ósseo. Houve a presença de áreas hemorrágicas com lise celular e tecido sutural amorfo. A presença de infiltrado inflamatório de polimorfonucleares caracterizou este período. A presença de áreas semi-hializadas também foi evidente neste período.

A superfície óssea sutural mostrou-se ainda de forma regular, com a presença de tecido osteóide, margeado por alguns osteoblastos volumosos localizados justapostos às superfícies. As cavidades medulares apresentaram células adiposas, e, células com núcleos esféricos, demonstrando serem células jovens (precursores). Estas células eram principalmente neutrófilos jovens, com núcleos grandes ovóides e claros, entremeando as células esféricas escuras. No interior do osso, os osteócitos tinham núcleos picnóticos. Notaram-se poucos osteoclastos nesta região (Figura 7, página 71). 


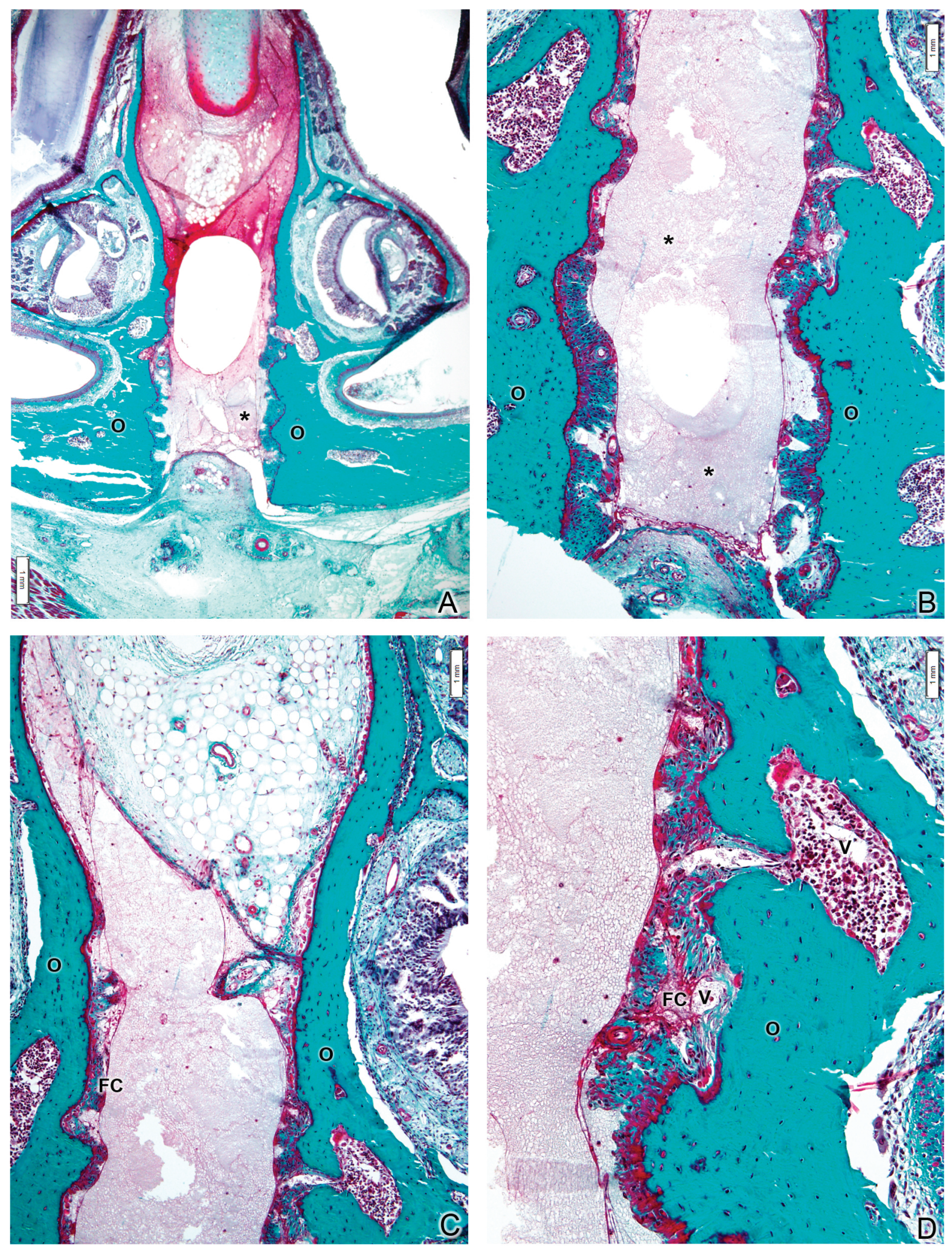

Figura 7 - Região da sutura palatina mediana do grupo Experimental II (dia 3). A) visão panorâmica mostrando a sutura palatina mediana com áreas hemorrágicas (*) em toda extensão da sutura. B) C) e D) observam-se fibras colágenas (FC) aderidas na superfície óssea (O) e vasos sanguíneos hiperêmicos (V). 



\section{c.2 Disjunção 7 dias + aplicação de laser}

O espaço sutural mostrou-se ainda amplo, quando comparado ao grupo controle. O tecido sutural em regeneração caracterizou-se por numerosos vasos sanguíneos dilatados próximos a bordas ósseas e vasos menores por o tecido conjuntivo. Fibroblastos, células mononucleares e alguns neutrófilos (polimorfonucleares) foram observados. A reabsorção óssea solapante e ativa não foi muito frequente neste período, sendo que os espaços medulares estavam recobertos por osteoblastos ativos. Notou-se a presença de trabéculas em desenvolvimento e tecido ósseo recém-formado recobrindo as bordas ósseas, principalmente no terço nasal (Figura 8, página 75). 


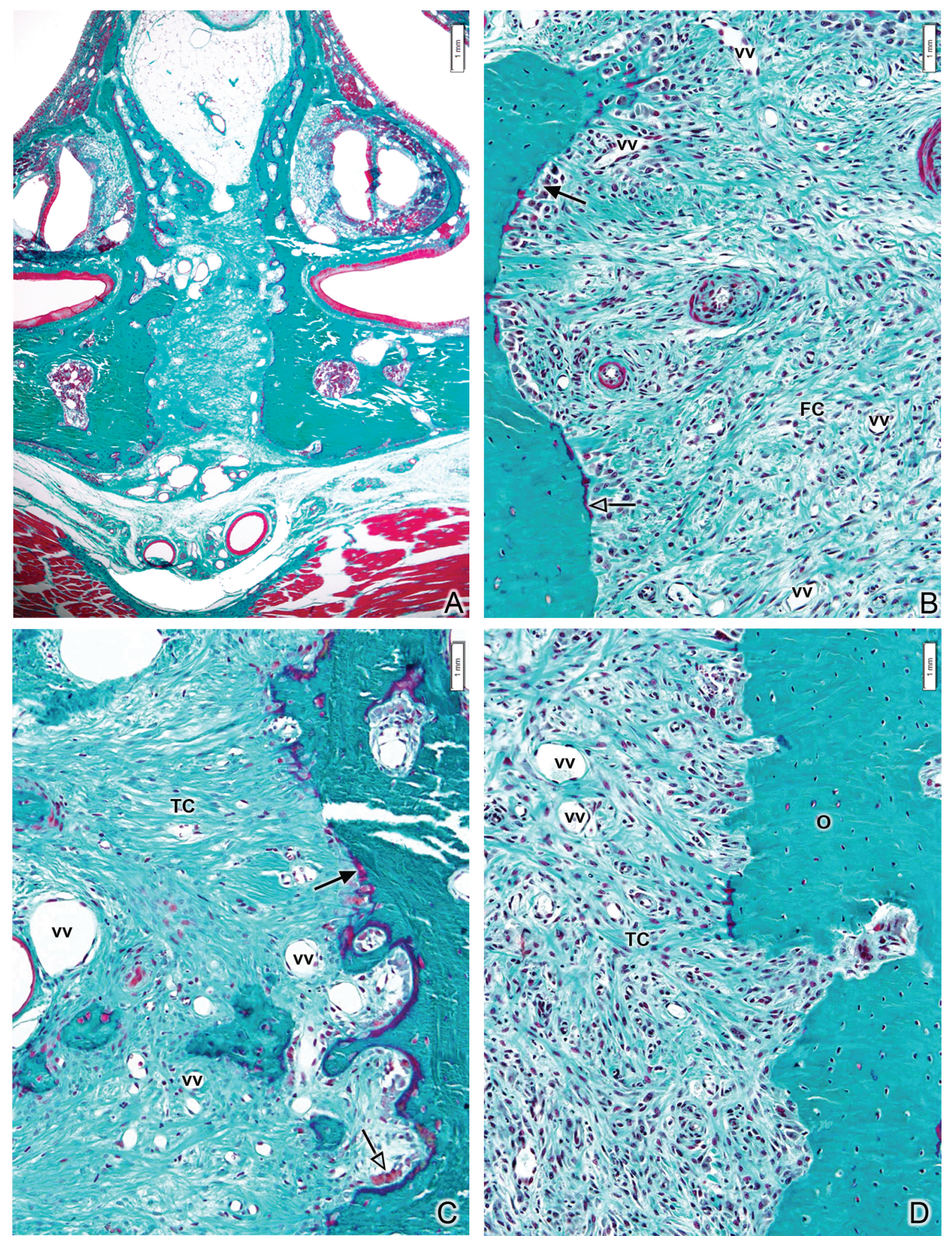

Figura 8 - Região da sutura palatina mediana do grupo Exp II ( $\left.7^{\circ} \mathrm{dia}\right)$. A) visão panorâmica mostrando a sutura palatina mediana com intensa proliferação de fibras colágagenas e vasos sanguíneos. B) observam-se fibras colágenas (FC) distribuídas em diversas direções repleto de vasos sanfguíneos (VV) e osteoblastos (setas vazadas) recobrindo a superfície óssea. C) osteoblastos (ОВ) ativos na superfície óssea e a linha de repouso entre o tecido ósseo antigo e o tecido ósseo novo (setas). D) Tecido ósseo neo-formado (O) tecido e conjuntivo (TC) repleto de vasos sanguíneos (VV). 



\section{c.3 Disjunção 10 dias + aplicação de laser}

O tecido sutural estava bastante celularizado em toda a sua extensão. Observou-se um acúmulo de pequenos vasos que ocorreu em todo tecido sutural sugestivo de proliferação vascular. Nosso critério para considerar, microscopicamente, a ocorrência de uma revascularização, através da coloração de H/E e Masson, foi a presença de um tecido vital (tecido conjuntivo com vasos sanguíneos, fibroblastos, outros tipos celulares na região central e áreas com fibras colágenas) sem a evidência de reação inflamatória, mas com poucas imagens sugestivas de degeneração de células. Notou-se também, numerosos fibroblastos, e grande quantidade de osteoblastos neste período. Os feixes de fibras colágenas estavam mais evidentes e organizados. Em alguns locais os osteoblastos estavam concentrados indicando local de desenvolvimento de trabéculas ósseas. As células da superfície óssea sutural eram volumosas em vários pontos indicando atividade de síntese. Notou-se também a presença de osteócitos volumosos, mas ainda existiam áreas com osteoplastos vazios. A presença de tecido osteóide, recoberto por osteoblastos ativos foi evidente (Figura 9, página 79). 


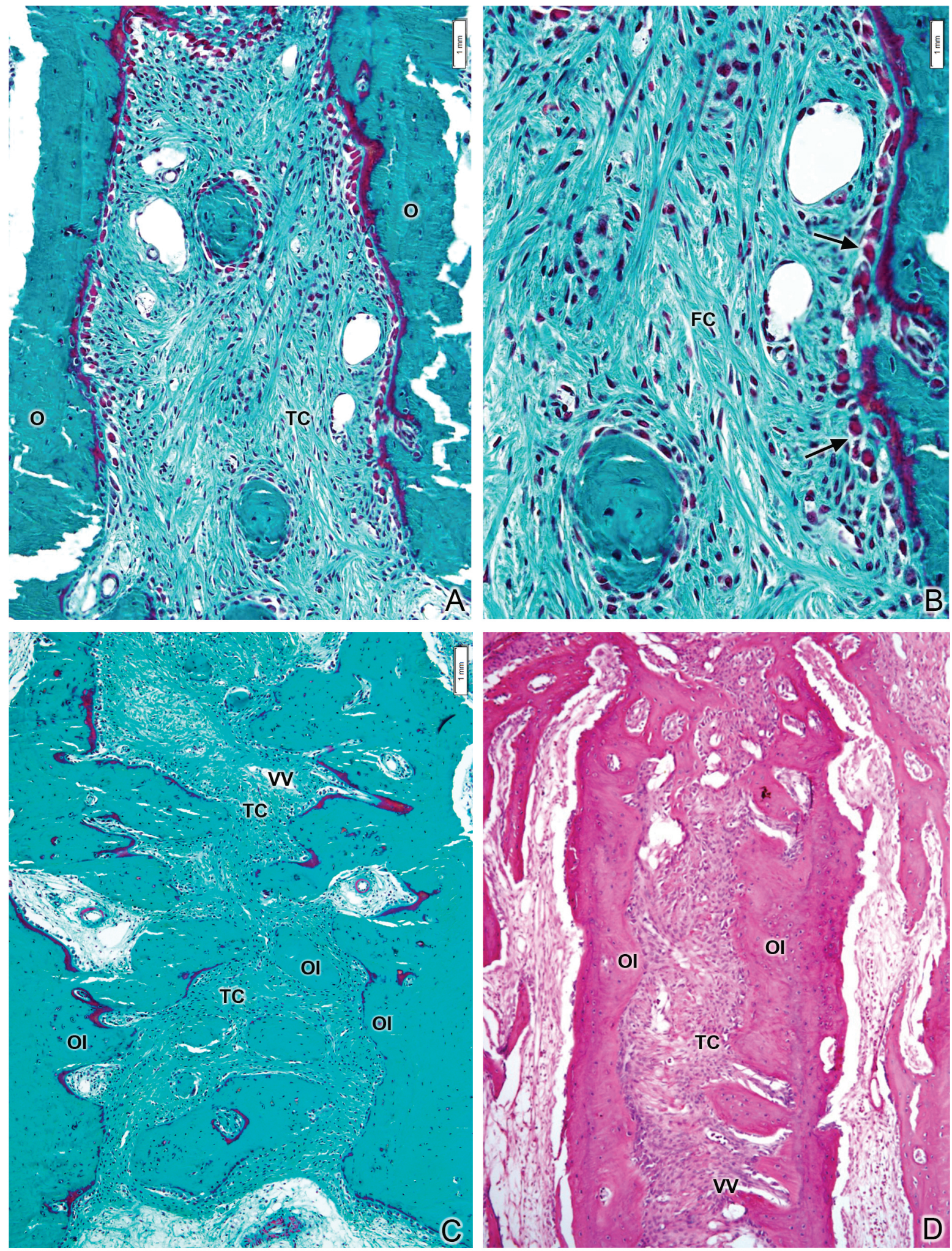

Figura 9 - Região da sutura palatina mediana do grupo Experimental II (10 $\mathrm{dia})$. A) visão panrâmica mostrando a sutura palatina mediana com intensa proliferação de fibras colágagenas. B) observam-se fibras colágenas (FC) distribuídas em diversas direções e osteoblastos (setas pretas) recobrindo a superfície óssea. C) e D) tecido ósseo imaturo (OI) delimitando o tecido conjuntivo altaente celular (TC) repleto de 



\subsection{Resultados dos escores e estatísticos}

\subsubsection{Processo Inflamatório}

Escore do Grau de inflamação $(1,2,3,4)$

\begin{tabular}{|c|c|c|c|c|c|c|c|c|c|}
\hline \multirow[b]{2}{*}{ Animais } & \multicolumn{3}{|c|}{3 dias } & \multicolumn{3}{|c|}{7 dias } & \multicolumn{3}{|c|}{10 dias } \\
\hline & Controle & Exp I & Exp II & Controle & Exp I & Exp II & Controle & Exp I & Exp II \\
\hline I & 1 & 4 & 3 & 1 & 4 & 2 & 1 & 3 & 1 \\
\hline II & 1 & 4 & 4 & 1 & 4 & 3 & 1 & 2 & 2 \\
\hline III & 1 & 4 & 3 & 1 & 3 & 2 & 1 & 2 & 1 \\
\hline IV & 1 & 4 & 3 & 1 & 3 & 2 & 1 & 2 & 1 \\
\hline V & 1 & 4 & 3 & 1 & 3 & 1 & 1 & 3 & 1 \\
\hline Mediana & 1 & 4 & 3 & 1 & 3 & 2 & 1 & 2 & 1 \\
\hline $1^{\circ}$ quartil & 1 & 4 & 3 & 1 & 3 & 1,5 & 1 & 2 & 1 \\
\hline $3^{\circ}$ quartil & 1 & 4 & 3,5 & 1 & 4 & 3 & 1 & 3 & 2 \\
\hline
\end{tabular}

Quadro 4 - Escore individual de cada espécime e mediana de cada grupo para a intensidade do processo inflamatório em todos os períodos para o Grupo Controle e experimentais

$\mathrm{Na}$ análise intragrupo houve uma diminuição significativa do número de células inflamatórias a partir do dia 7 no Grupo Experimental I (ERM) a partir do dia 3 no Grupo Experimental II (ERM + LBP), sendo está redução muito mais significativa no grupo irradiado.
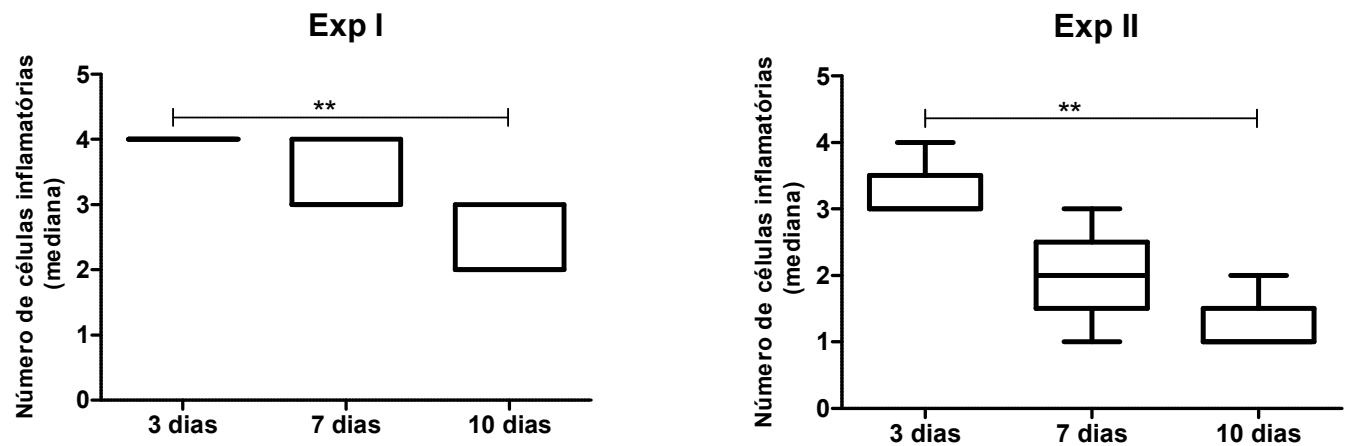

Figura 10 - Expressão da mediana, amplitude interquartil, valores máximos e mínimos dos escores de número de células inflamatórias ( $p<0,05$; Kruskal-Wallis, teste de Dunn). Os dados correspondem a 10 dias de experimento. 


\subsection{Análise do RNAm}

\subsubsection{RT-PCR}

Para a avaliação da influência do laser de baixa potência sobre a expressão gênica durante o reparo ósseo alveolar, os níveis de RNAm foram quantificados utilizando-se como referência a expressão do gene GAPDH, por meio de PCR quantitativo em tempo real para os grupos experimentais (I e II) e grupo controle (GC). O teste ANOVA, seguido do teste de Tukey, comparou os valores médios entre os grupos experimentais (I e II) e grupo controle (GC).

Os valores relativos à produção do gene VEGF durante a remodelação óssea em ratos induzidos à ERM e aplicação do LBP, nos diversos períodos analisados, encontram-se representados nas Figuras 11 e 12.

a) Grupo Controle, Experimental I e Experimental II

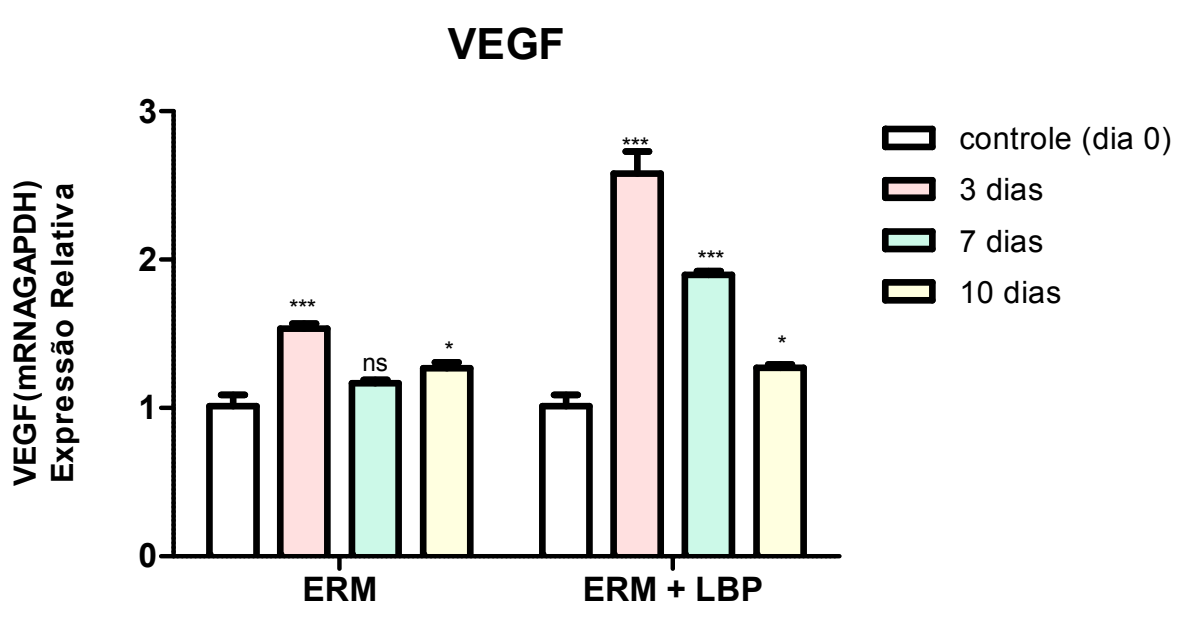

Figura 11 - Expressão de RNAm VEGF no Grupo Experimental I, II e Controle. Os dados correspondem a 10 dias de experimento, comparado com o controle. Os resultados estão expressos em média e desvio padrão. ${ }^{*} p<0,05 ;{ }^{* * *} p<0,001$, ns=não significante.

Ao avaliar o RNA $A_{m}$ para VEGF observou-se que este gene estava expresso em todos os períodos e foram estatisticamente significante quando comparado ao controle. Para a expressão do gene VEGF a análise intragrupo demonstrou que, para o grupo Exp I houve um abrupto e significativo aumento a partir do $3^{\circ}$ dia 
quando comparado ao controle $(p<0,001)$. Da mesma forma, ao avaliar o RNA $A_{m}$ para VEGF no grupo Exp II, houve um aumento significativo a partir do $3^{\circ}$ dia quando comparado com ao controle $(p<0,001)$. A partir de 10 dias houve uma redução do nível de expressão de RNA $A_{m}$, porém continuou em nível mais elevado que o controle (Figura 11, página 82).

\section{b) Grupo Experimental I e Experimental II}

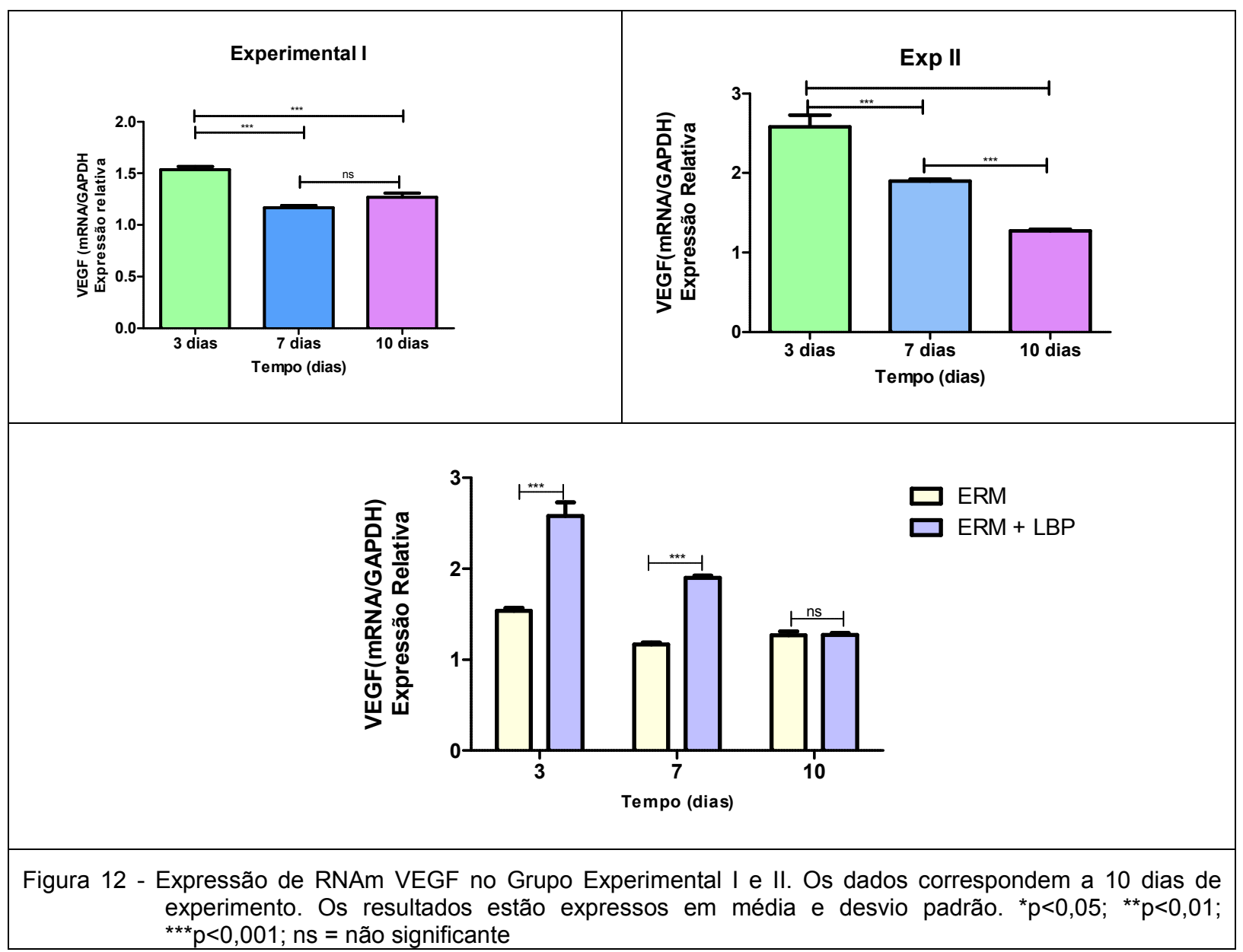

A análise intergrupo demonstrou um aumento siginificativo na expressão do RNA $_{m}$ de VEGF após 3 e 7 dias do experimento $(p<0,001)$ no grupo Exp II comparado ao Exp I. A partir de 10 dias houve uma diminuição na expressão do VEGF no grupo experimental II quando comparado aos períodos iniciais não sendo estatisticamente significativo aos 10 dias (Figura 12). 


\subsubsection{Análise da expressão de proteína - Western Blotting}

Esta análise foi feita para detectar a intensidade da expressão da proteína VEGF, utilizando-se como referência a expressão protêica do GAPDH. O teste ANOVA, seguido do teste de Tukey, relacionou os valores médios entre os grupos experimentais (I e II) e grupo controle (GC).

Os valores densitométricos médios das bandas obtidas para a proteína VEGF durante a remodelação óssea em ratos induzidos à expansão rápida da maxila e aplicação do laser de baixa potência, nos diversos períodos analisados, encontram-se representados nas Figuras 13 e 14.

\section{a) Grupo Controle, Experimental I e Experimental II}

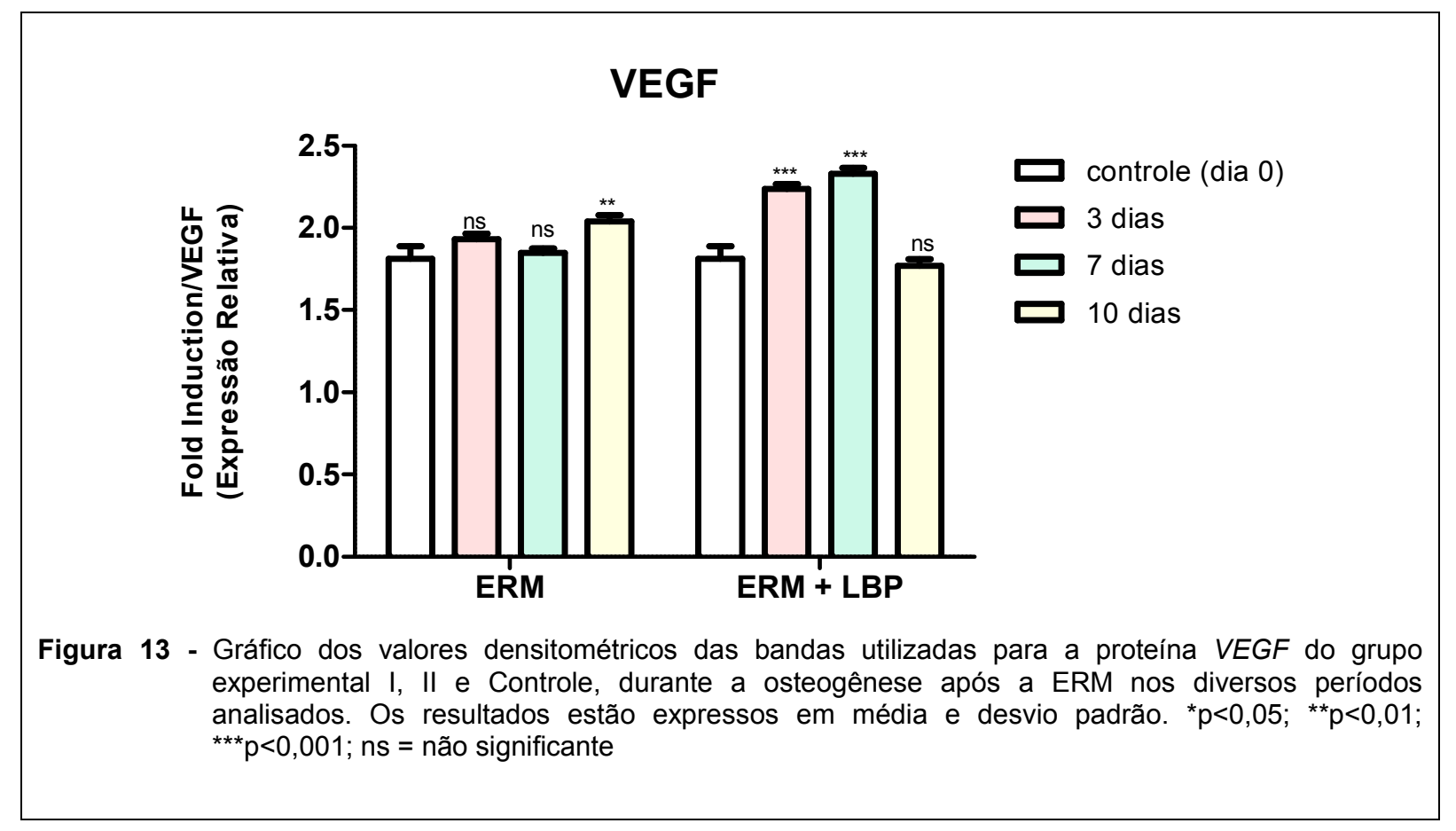

No grupo Experimental I houve um aumento da expressão protêica de VEGF em todos os períodos analisados, sendo que só nos períodos de 10 dias apresentaram diferenças estatisticamente significantes $(p<0,001)$ em relação ao controle (0,22 vezes maior). A expressão protêica do VEGF nos períodos de $3,7 \mathrm{e}$ 10 dias foi em média 0,12 (ns); 0,02 (ns) e 0,22 ( $p<0,001$ ) vezes maior em relação grupo controle (Figura 13). 
No grupo experimental II observamos que a expressão da proteína VEGF teve um aumento significativo nos períodos de 3 e 7 dias sendo 0,42 e 0,51 vezes maior que o controle. No período de 10 dias $(p<0,05)$ observou-se um declínio do VEGF, porém não significativo, sendo em média 0,02 vezes menor que o controle (Figura 13).

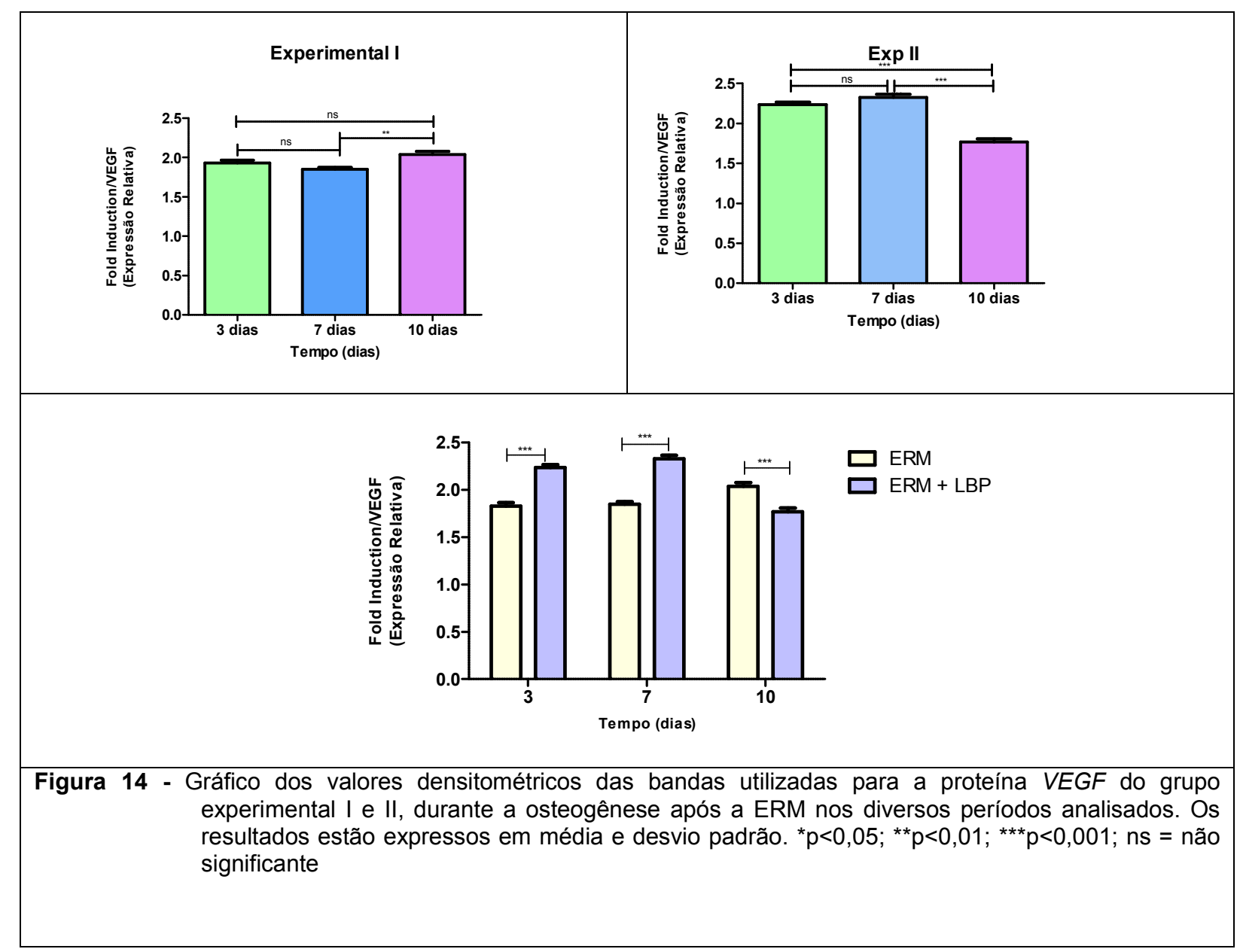

Quando comparamos o grupo experimental I com o II a expressão protêica do VEGF no grupo Experimental II mostrou um aumento significativo nos períodos de 3 e 7 dias em relação ao grupo Experimental I $(p<0,01)$ dias, apresentando em média 0,3 e 0,48 vezes maior no grupo Experimental II. Aos 10 dias dias também houve uma diminuição média significativa de 0,24 vezes em relação ao Experimental I (Figura 14). 



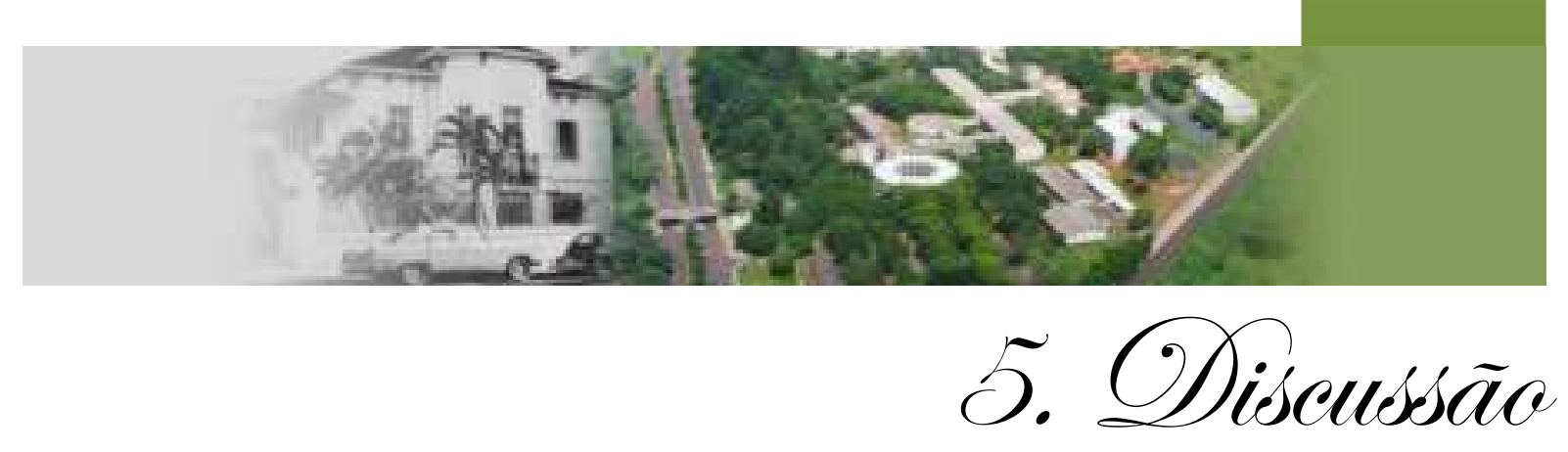





\section{DISCUSSÃO}

Nos últimos anos vem aumentando o número de pacientes com maloclusões causadas pela maxila atrésica na clínica ortodôntica. $O$ tratamento desta maloclusão se faz com a expansão rápida da maxila (ERM), ou seja, com o alargamento da arcada dentária superior. Porém, para obter êxito no tratamento ortodôntico, há necessidade de formação óssea na sutura palatina mediana após a disjunção da maxila, evitando-se dessa forma a recidiva do tratamento. O laser de baixa potência vem sendo utilizado na Odontologia com o objetivo de acelerar a cicatrização de tecidos moles e duros, mas ainda de maneira empírica, pois não existe um protocolo único para a sua utilização (ANGELETTI et al., 2010). Dado a importância funcional da participação dos vasos sanguíneos no reparo tecidual e a escassez de estudos que mostram ao nível molecular a produção das moléculas VEGF após a ERM, e aplicação do laser de baixa potência (LBP), o presente estudo propôs identificar e quantificar essa proteína que participam do processo de reparo ósseo em diferentes períodos de ERM e aplicação do LBP.

Assim, o objetivo desta pesquisa foi verificar a participação da proteína VEGF envolvida com a vascularização primordial para que ocorra a remodelação óssea da sutura palatina mediana após a aplicação de forças ortopédicas, trazendo com isso novas informações a respeito da dinâmica do tecido ósseo, a nível molecular e uma melhor compreensão da biologia do tecido ósseo, ajudando o Ortodontista entender o mecanismo da remodelação óssea após a ERM. Da mesma forma foi possível verificar a ação do LBP na vascularização e a possibilidade desse mecanismo diminuir o tempo de contenção após a disjunção maxilar, acelerando o reparo ósseo e acelerando a vascularização local.

Os modelos animais têm sido largamente utilizados em benefício da compreensão da remodelação óssea após a aplicação de forças ortodôntica e/ou ortopédicas. Embora não se possam esperar respostas idênticas à agressões semelhantes entre as diferentes espécies, estes modelos podem funcionar como exemplos de tendências biológicas e fornecer informações importantes ao 
pesquisador. Neste sentido, os ratos geralmente são alvo de estudos experimentais, para este propósito, devido à disponibilidade, facilidade de manipulação, grandes semelhanças com os humanos, baixo custo da pesquisa e padronização da amostra (OSAWA et al. 1998; SAITO; SHIMIZU, 1997; SAWADA; SHIMIZU, 1996; TRELLES; MAYAYO, 1987).

Em geral, o melhor modelo para remodelação óssea é aquele capaz de mimetizar a situação clínica. Para tanto, vários sistemas testes têm sido utilizados, entre eles, o reparo de fraturas, a perda segmental em osso longo, o defeito de tamanho crítico em crânio, a reparação de alvéolo dentário de incisivo central superior de ratos após exodontia e o da reparação de defeito ósseo uni-cortical criado experimentalmente em fêmur ou tíbia de coelhos. No entanto, esses modelos produzidos cirurgicamente tem o inconveniente de apresentarem capacidade de reparação espontânea, o que foi evitado com a utilização da ERM, executada na presente pesquisa.

Embora conscientes de algumas limitações com a utilização de ratos como modelo experimental, optou-se como modelo experimental, o uso destes animais, utilizando um dispositivo ortodôntico para realizar a expansão rápida da maxila, de tal forma a manter separadas as duas hemi-maxilas, e procurou-se verificar a vascularização através da identificação do gene e da proteína VEGF, com e sem aplicação do laser de baixa potência.

Quanto a estabilidade do aparelho disjuntor e a remodelação da sutura, os resultados mostraram que durante todo o periodo experimental não houve movimentação dos incisivos superiores e nem diferenças clínicas entre os grupos experimentais, portanto não houve interferência nos eventos inicias da remodelação óssea confirmando que o aparelho disjuntor permaneceu bem fixado entre os dentes.

Este modelo proporcionou uma expansão cirúrgica fechada da sutura palatina mediana, porém sem o inconveniente dos procedimentos cirúrgicos convencionais, uma vez que não há a exposição do periósteo durante este procedimento, evitando-se desta forma qualquer tipo de infecção ao local. Tal procedimento é o mesmo princípio que se utiliza rotineiramente em humanos quando se deseja expandir a arcada dentária superior, com o objetivo de alargar a 
base maxilar. Neste experimento todos os animais permaneceram saudáveis e não houve perda de peso de modo expressivo durante o período experimental devido ao uso do dispositivo ortodôntico. Não houve nenhuma dificuldade durante a instalação do aparelho expansor e, o mesmo não causou nenhum desconforto aparente aos animais. Ao mesmo tempo, foi verificada a abertura da sutura palatina mediana, que foi comprovada através de radiografias oclusais de controle bem como pelas análises histológicas pós-expansão (Figura 13 à Figura 20), mostrando a efetividade de tal procedimento.

Os efeitos de irradiação de laser em regeneração de osso na sutura não estão totalmente esclarecidos, pois a maioria dos estudos para verificar a formação óssea utiliza campos cirurgicamente preparados, que possuem um potencial natural de reparação, além disso, esses campos se localizam normalmente fora da cavidade bucal. O uso potencial do laser na biomodulação do reparo ósseo através de suas propriedades fotoquímicas e fotobiológicas tem sido estudado por pesquisadores em todo o mundo com o objetivo de proporcionar ao paciente, uma maior rapidez na cicatrização óssea, amenizando o quadro de edema pós-cirúrgico, melhorando a cicatrização tecidual e, portanto, menor desconforto pós-operatório. Porém, os efeitos do LBP no osso ainda são controversos, pois estudos têm mostrado resultados conflitantes (KARU et al., 1989; IN DE BRAEKT et al., 1991; NISSAN et al., 2006; SEIFI et al., 2007; AAI-AQL et al., 2008; ANGELETTI et al., 2010). A terapia com laser tem sido considerada como responsável pela biomodulação na cicatrização de fraturas ósseas em modelos animais, baseado em estudos morfogenéticos, bioquímicos e de microscopia eletrônica. Desta forma a laserterapia tem sido apontada como capaz de modular várias respostas biológicas afetadas por alguns fatores envolvidos com o modo da radiação, tais como: dose total de energia, comprimento de onda, densidade de potência, tipo de emissão e tempo de radiação (BRUGNERA JÚNIOR; PINHEIRO, 1998; BRUGNERA JÚNIOR et al., 2003). Os resultados da presente pesquisa mostraram uma aparente melhora na remodelação óssea e na vascularização tecidual, quando se comparou o grupo irradiado com o não irradiado, resultados estes que serão discutidos posteriormente. Porém para esclarecer a efetividade da laserterapia na remodelação óssea é necessária comprovação clínica de médio e longo prazo, que possam demonstrar o desempenho do LBP. 
A ocorrência de uma fratura óssea ou de uma deformação no osso como no caso de aplicação de forças ortodônticas e/ou ortopédica provoca solubilização e liberação de proteínas. Uma vez ativadas, elas ligam-se a receptores específicos da membrana celular dos osteoblastos e outras células envolvidas no reparo ósseo, estimulando a expressão de genes responsáveis pelo desencadeamento e perpetuação do processo de remodelação óssea (UEDA; SHIMIZU, 2003; PINHEIRO et al., 2003; ROBLING; CASTILLO; TURNER, 2006; SEIFI et al., 2007; AAI-AQL et al., 2008). Portanto o processo de reparo está diretamente dependente da resposta celular local ao estímulo gerado pelos fatores de crescimento do tecido ósseo (WLODARSKI, 1990; SEIFI et al., 2007; AAI-AQL et al., 2008).

Porém, para que uma resposta tecidual favorável ocorra, algumas condições são essenciais, dentre elas inclui-se a presença de células e nutrição adequadas das mesmas e um estímulo para a reparação óssea. Os mecanismos exatos implicados in vivo na gênese do tecido ósseo são controversos, envolvendo uma complexa interação de fatores reguladores locais e sistêmicos. A ação destes mediadores promove um equilíbrio contínuo entre formação (osteoblastos) e reabsorção (osteoclastos) óssea. A aplicação de uma força ortodôntica e/ou ortopédica sobre o osso representa uma quebra desta relação, desencadeando uma série de eventos intra e extracelulares que culminam com o reparo do tecido lesado (SAITO; SHIMIZU, 1997; GIORDANO; GIORDANO; KNACKFUSS, 2003; SEIFI et al., 2007). A força ortopédica produzida com o dispositivo utilizado nesta pesquisa produziu a abertura da sutura palatina mediana rompendo o equilíbrio do tecido ósseo e sutural. A principal vantagem desse procedimento é pelo fato de ser intraoral e fechado (campo não cirúrgico), não houve a presença de infecção após este procedimento, o que poderia interferir nos resultados apresentados aqui. Estes achados foram confirmados através do exame histológico realizado nesta pesquisa. Apesar de apresentar um processo hemorrágico inicial na sutura palatina mediana, o que é comum neste procedimento, não foi observado nos exames histológicos o processo infeccioso na região. A presença de células inflamatórias, principalmente no período de 3 dias, foi devido ao trauma provocado pela ERM e não por infecção no campo, caracterizando um processo inflamatório asséptico comuns nos casos de aplicação de forças aos dentes (KRISHNAN; DAVIDOVITCH, 2009). 
Tem sido relatado, que uma vez ativadas, as proteínas ligam-se a receptores específicos da membrana celular de osteoblastos e em outras células envolvidas no reparo, estimulando a expressão de genes responsáveis pelo desencadeamento e perpetuação do processo de neoformação óssea. Em termos de interação célulacélula, manifestam duas formas distintas de atuação. Estimulam localmente a proliferação e diferenciação celular e, síntese de nova matriz protêica (efeito parácrino); além disso, possuem um mecanismo de autorregulação sobre os osteoblastos, induzindo contínua expressão dos fatores de crescimento do tecido ósseo (efeito autócrino).

O mecanismo do complexo celular responsável pela adaptação funcional dos ossos está começando a ser decifrado através da biologia molecular (BRIGHTON et al., 1996; OWAN et al., 1997; COWIN, 1998). Os sinais intracelulares são complexos e ainda não estão totalmente entendidos. É sabido que as cargas comprimem e dobram o tecido ósseo, causando uma deformação local ou estiramento da matriz extracelular e cria um fluxo do fluído nos espaços pericelulares, especialmente na extensa rede de canalículos dos osteócitos (COWIN, 2007) Isso pode ser observado no Grupo Experimental I, que só sofreu a ERM, que caracteriza um trauma ao tecido ósseo, onde se observou um aumento imediato (24 horas) da expressão do RNAm do VEGF, concordando com relatos da literatura (HILL, 1998), onde mostram que a força ortodôntica pode ser suficiente para ativar essas proteínas. O conceito atual de remodelação óssea se baseia na hipótese de que os precursores osteoclásticos se ativam e se diferenciam em osteoclastos e iniciam o processo de reabsorção óssea sendo seguida por uma fase de formação óssea. Na presente pesquisa o trauma ao tecido ósseo provocado pela ERM ativou o aumento na expressão do RNAm de VEGF 24hs após a aplicação da força ortodôntica, sendo a expressão da proteína VEGF expressiva imediatamente após a ERM.

A sequência de ocorrências no ciclo da remodelação óssea normal é sempre a mesma, ou seja, reabsorção óssea osteoclástica, uma fase reversa e formação óssea osteoblástica para reparar o defeito. A formação óssea resulta de uma complexa cascata de ocorrências que envolvem a proliferação de células mesenquimais primitivas, diferenciação em células precursoras osteoblásticas, maturação dos osteoblastos, formação de matriz e, finalmente, mineralização. 
Quando existe uma cavidade reabsorvida, os osteoblastos convergem para ela e formam o osteóide que começam a mineralizar-se após 13 dias. Os osteoblastos continuam a formar e mineralizar o osteóide até que a cavidade seja totalmente preenchida. O tempo para preencher uma cavidade em qualquer ponto sobre a superfície óssea é de 124-168 dias em humanos normais (HILL, 1998), e esse tempo passa a ser de 21 dias para ratos.

A angiogênese é um processo complexo que resulta na remodelação da matriz extracelular, secreção de enzimas proteolíticas, migração das células endoteliais, proliferação, diferenciação capilar e anastomoses (FOLKMAN; KLAGSBRUN, 1987; FOLKMAN; SHING, 1992), e esse processo é regulado pela interação de inúmeras citocinas e fatores de crescimento (GARANT, 2003). O VEGF é a chave reguladora da angiogênese fisiológica durante o crescimento esqueletal e funções reprodutivas (FERRARA, 1996, 2000; FERRARA, GERBER; LECOUTER, 2003). O VEGF está envolvido no processo de angiogênese no qual os novos vasos sanguíneos são formados a partir de outros vasos pré-existentes, funcionando como um potente fator pró-sobrevivência (antiapoptótico) para células endoteliais (FERRARA, 1996, 2004; FERRARA, GERBER; LECOUTER, 2003) em vasos recém-formados. Portanto, é considerado um dos responsáveis pela promoção de revascularização dos tecidos isquêmicos (KORANSKY; ROBBINS; BLAU, 2002; GOUNIS et al., 2005) e formação de vasos sanguíneos (YANCOPOULOS et al., 2000).

Nos grupos experimentais (irradiado e não irradiado) ocorreu o aumento da expressão de VEGF pelas células ósseas, indicando, a ocorrência de uma íntima relação entre a angiogênese, o processo reabsorptivo e a formação óssea. A expressão de VEGF é induzida por vários mediadores inflamatórios, tais como a interleucina-6, interleucina-1, prostaglandinas e, também, pela endotoxina LPS (lipopolissacarídeos) (GOODIS; SAEKI, 1997; STASHENKO; TELLES; D'SOUZA, 1998; BOTERO et al., 2003). O VEGF é em grande parte responsável pelo estímulo da proliferação e diferenciação de células endoteliais, e, consequentemente, pelo aumento da permeabilidade vascular e formação de novos vasos sanguíneos, sendo um potente fator angiogênico (FERRARA; GERBER; LECOUTER, 2003; FERRARA, 2004). Portanto, sua alta expressão durante o período de inflamação contribui para a formação de edema e consequente dor. A presente pesquisa mostrou 
histologicamente processo inflamatório intenso no período de 3 dias principalmente no grupo Experimental I e também foi observado um aumento da expressão gênica do VEGF neste grupo, mostrando a íntima relação entre vascularização e processo inflamatório.

No presente estudo os resultados obtidos RT-PCR mostraram que houve diferença estatisticamente significativa $(p<0,001)$ na expressão de RNAm para VEGF no grupo que sofreu a ERM (Exp I) e naquele que foi submetido à disjunção e aplicação de laser (Exp II) em todos os períodos em relação ao controle, demostrando que o trauma estimula a liberação de VEGF na tentativa de aumentar a vascularização da área, provavelmente devido ao processo inflamatório presente no local produzido pelo trauma da ERM. Quando se comparou os dois grupos (laser e não laser) se observou que a laserterapia diminuiu a expressão de RNAm do VEGF a partir de 7 dias após a ERM, sendo que no período de 3 dias houve um aumento na expressão do VEGF no grupo irradiado, provavelmente devido ao aumento da vascularização inicial e processo inflamatório que este procedimento produziu, como relatado na literatura. Este resultado foi confirmado pelo western blotting (Figura 14, página 69).

Elevados níveis de VEGF têem sido detectados durante a fase inicial do processo inflamatório e estão presentes em tecidos como células endoteliais inativas, confirmando a importância do VEGF em potencializar a angiogênese numa variedade de tecidos, respondendo a diversos sinais. Os elevados níveis de VEGF observados na presente pesquisa confirmam os relatos da literatura, mostrando que não só o trauma ao tecido ósseo como também a irradiação a laser estimulou a liberação da proteína VEGF, observado pelo Western blotting. Entretanto, várias questões básicas ainda não estão completamente respondidas. Há fortes evidências de que as ações do VEGF no endotélio vascular são complexas e não limitadas somente à indução do crescimento vascular. Sabe-se que, o VEGF é um potente fator angiogênico, e que seus receptores têm sido localizados principalmente em células endoteliais. Porém, atualmente tem-se demonstrado que o VEGF também participa de vários outros eventos celulares e teciduais que envolvem a formação e a remodelação do tecido cartilaginoso e ósseo. Algumas implicações clínicas interessantes do VEGF estão relacionadas ao seu envolvimento no processo de angiogênese óssea. A aplicação desse fator de crescimento vascular endotelial pode 
ser útil para melhorar o processo de revascularização em casos de fraturas não consolidadas e em outras condições (FERRARA; GERBER; LECOUTER, 2003), como por exemplo, em casos de necroses ósseas (KATSUBE et al., 2005)' bem como no controle do processo inflamatório, o que pode ser verificado no presente experimento com a aplicação do laser de baixa potência. Observou-se nesse experimento que o LBP aumentou a expressão de RNAm do VEGF 3 dias após a ERM imediata, e após este período, houve uma diminuição demonstrando o controle do processo inflamatório produzido pelo laser, dados que podem ser confirmados pelo exame histológico.

Um aspecto relevante do VEGF é que o mesmo tem sua resposta altamente vinculada ao tipo de meio ambiente em que se encontra (POLVERINI, 2002). Além dos fatores de crescimento e citocinas a tensão de oxigênio é um regulador importante do VEGF (HICKLIN; ELLIS, 2005). Condições de hipóxia desempenham um papel importante na regulação da expressão de uma variedade de genes. A expressão de VEGF mRNA é induzida por exposição à baixa tensão de oxigênio. Esta condição desempenha a função de recrutar vasos sanguíneos para áreas de tecido isquêmico (FERRARA; GERBER; LECOUTER, 2003). Em contraste, condições de hipóxia normal, sub-regulam a produção de VEGF e promovem a regressão de vasos sanguíneos recém-formados. Quando as condições de hipóxia predominam, como no caso do crescimento tumoral, a expressão de VEGF persiste, potencializando, assim, o processo de angiogênese e, consequentemente, a progressão tumoral. Esse fator de crescimento vascular endotelial tem sido relacionado com a angiogênese patológica associada a tumores, alterações neovasculares intra-oculares e outras condições. A literatura (FERRARA, 2004) suporta a hipótese de que o VEGF é o maior mediador da angiogênese associada com várias alterações. De fato, VEGF e seus inibidores constituem uma das melhores alternativas de tratamento para a inibição de tumores. A angiogênese está intimamente relacionada com o crescimento, progressão e metástase dos tumores. Apesar de o VEGF ser considerado o fator central na regulação do processo de angiogênese, não esta relacionado somente ao câncer. Trabalhos encontrados na literatura (BOOTH et al.,1998), demonstraram a presença do VEGF na doença periodontal inflamatória crônica, mas também, observaram a presença de VEGF em áreas livres de inflamação (periodonto saudável) ratificando o papel do mesmo na 
angiogênese fisiológica da gengiva e ambiente periodontal, o que está de acordo com o presente experimento, pois a expressão de RNAm VEGF também foi observado no grupo controle, onde nenhum procedimento foi realizado.

No presente experimento houve uma condição praticamente inevitável de hipóxia gerada por isquemia nos tecidos da sutura palatina mediana após aplicação da força ortopédica, o mesmo sendo relatado na literatura (KRISHNAN e DAVIDOVITCH, 2009), o que por si só já seria um estímulo para a expressão de VEGF (ARTESE et al., 2002; HARIK, HRITZ; LAMANNA, 1995; PE'ER et al., 1995), sendo este um estímulo fundamental que explicaria a grande expressão desta citocina, tanto no grupo experimental I quanto no Grupo Experimental II. Os resultados desse estudo mostraram níveis de VEGF sendo expresso em maior quantidade nos grupos experimentais do que os níveis basais encontrados (Grupo controle). Baseando-se em informações relatadas por outros autores (BOOTH et al.,1998), que afirmam que macrófagos e fibroblastos parecem ser atraídos para áreas com baixa oxigenação, pode-se supor que a expressão de VEGF na área da sutura foi significativamente aumentada em um primeiro momento, em virtude da tração das fibras da sutura palatina. À medida que a irrigação local se restabelece, desencadeada por mecanismos angiogênicos desempenhados, sobretudo, pelas células endoteliais, secretoras de VEGF, retomam os níveis normais de oxigenação local. Esse dado, por sua vez, explicaria a diminuição de VEGF num segundo tempo de avaliação, onde há caracteristicamente novos vasos ainda secretando VEGF, mas não mais ocorrem células elásticas, características dos três primeiros dias de tracionamento das fibras. O nível de expressão de VEGF, ao final de sete dias voltou a subir. Isso pode ser explicado pela evidência histológica de reorganização do tecido de sustentação o que está de acordo relatos da literatura (KRISHNAN e DAVIDOVITCH, 2009).

A importância da vascularização tem sido amplamente estudada durante o processo de ossificação, associada à liberação de fatores osteogênicos, como o VEGF, culminando com o aumento da vascularização e da liberação de fatores indutores da osteoclastogênese e osteoblastogênese e pelas células endoteliais, além de, servir de via de transporte para as células hematopoiéticas com a chegada ao local dos precursores dos osteoclastos que degradam a matriz cartilaginosa, ativando a osteoblastogênese a partir da diferenciação das células mesenquimais 
indiferenciadas (IMHOF; DUNON, 1997; OLSEN; REGINATO; WANG, 2000). A comunicação parácrina, tanto in vitro quanto in vivo, entre as células endoteliais e osteoblásticas (via junções gap) controla o processo angiogênico necessário para a formação e o reparo ósseo (VILLARS et al.; 2000; VILLARS et al.; 2002).

Durante a ossificação endocondral, os condrócitos hipertróficos secretam VEGF para que a vascularização seja estabelecida, trazendo para o local, componentes hematopoiéticos, que se diferenciam em osteoclastos para a degradação da cartilagem mineralizada. Este gatilho, ativa a osteoblastogênese a partir das células progenitoras mesenquimais, culminando com a produção da matriz óssea e medular (OLSEN; REGINATO; WANG, 2000). Para o recrutamento de osteoclastos para as áreas de reabsorção, precursores de osteoclastos necessitam aderir e migrar através do endotélio em um fino e regulado mecanismo similar ao processo de transmigração de leucócitos e monócitos (IMHOF; DUNON, 1997). Atualmente, tem sido proposto que, o endotélio pode direcionar os precursores de osteoclastos para áreas específicas do tecido ósseo, ajudando a controlar o processo reabsortivo (PARFITT 2002a, b, c).

Na região submetida à força ortopédica (disjunção), ocorreu um aumento notável na expressão de VEGF, tanto no grupo experimental I quanto no II quando comparado com o controle, sendo em grande parte expresso pelo número elevado de osteoclastos, verificados no exame histológico, nesses períodos. Este fator de crescimento pode participar da função de remoção do tecido necrótico e a presença de maior suprimento sanguíneo na zona de tensão foi uma constante neste experimento. Pesquisas evidenciam que a injeção de VEGF acelera o processo de diferenciação osteoclástica. Kaku et al. (2001) investigaram se o VEGF recombinante estimularia a diferenciação de colônias de osteoclastos durante o movimento ortodôntico experimental. Para isso, injetaram VEGF recombinante no sulco gengival dos incisivos superiores de ratos e, após aplicação de força biomecânica, observou que o número de osteoclastos no lado de pressão foi muito maior. Os autores, diante dos resultados obtidos, sugeriram que a administração local de VEGF recombinante pode aumentar o nível de movimentação dentária induzida por aplicação de força mecânica. De acordo com os achados desse estudo, observa-se que a expressão de VEGF é estimulada por aplicação de força mecânica. Sugere-se que essa proteína influencia no recrutamento de células 
elásticas, pois se sabe que além de ser um dos principais fatores envolvidos no processo angiogênico, o VEGF também propicia o aumento da permeabilidade vascular (KAKU et al., 2001). O VEGF, confirmando o que já foi relatado anteriormente, tem a capacidade de induzir a função osteoclástica, assim como a neovascularização. Os resultados da presente pesquisa confirmam relatos publicados anteriormente Kohno et al., (2003) que também sugerem que o VEGF aumenta expressivamente, após estímulo mecânico, o número de osteoclastos como um fator parácrino e que a movimentação ortodôntica é acelerada tanto pelo VEGF endógeno quanto pelo VEGF recombinante. A utilização dessa proteína poderá futuramente ser muito útil na clínica ortodôntica.

Os níveis aparentemente aumentados de VEGF encontrados na presente pesquisa podem ser explicados principalmente pela remodelação do tecido sutural, sendo que esta reação envolve basicamente o tecido conjuntivo da sutura e osso adjacente Uma segunda possibilidade é que as ações desempenhadas pelo VEGF estão ligadas mais diretamente aos processos de neovascularização do tecido de inserção, pois o VEGF é um peptídeo que desempenha papel muito específico na angiogênese. O laser de baixa potência foi eficiente quando aplicado por três dias seguidos, onde observou que todos os períodos mostraram uma expressão maior do VEGF.

No presente estudo a vascularização foi substancial em todos os períodos, sendo que nos períodos iniciais esteve associada à remoção do coágulo e mais tarde à reabsorção e a formação óssea. Até o período de sete dias a superfície óssea sutural mostrou histologicamente, áreas de reabsorção com grande número de lacunas de Howship e, inclusive, presença de osteoclastos multinucleados ativos, com citoplasma abundante, dispostos em cadeia a esta superfície, isolados ou em pequenos grupos caracterizando intensa atividade de absorção óssea frontal, deixando a superfície óssea irregular, recortada, com várias lacunas de Howship distribuídas em sua extensão. Neste período observou-se uma maior expressão de VEGF tanto no grupo irradiado quanto no não-irradiado. Até o período de 10 dias, a neovascularização, observada histológicamente, exibiu o mesmo padrão de formação estando associada, principalmente, a formação do tecido conjuntivo, com invasão do coágulo sanguíneo a partir dos vasos preexistentes localizados nos tecidos adjacentes ao defeito ósseo e subsequente formação do tecido de 
granulação, um tecido conjuntivo frouxo, ricamente celularizado e vascularizado. Aos 10 dias, embora o tecido conjuntivo diminuísse pela sua substituição por tecido ósseo, nas bordas da sutura, o percentual de vasos no tecido conjuntivo manteve-se constante.

O elevado índice de expressão do VEGF no Grupo Experimental I em relação ao Grupo Experimental II pode ser observado e quantificado pela análise do RT-PCR e pela análise das bandas protêicas obtidas por western btotting. Diferencialmente, das outras proteínas, a expressão inicial do VEGF foi observada em áreas que foram invadidas pelo coágulo sanguíneo reabsorvido por células macrofágicas. A presença do VEGF, detectada pelo western btotting, imediatamente após a ERM, estava relacionada ao coágulo sanguíneo como observado por Street et al. (2002). Estas áreas também estavam associadas às áreas de reabsorção e neoformação óssea, demonstrando a importante participação do VEGF na vascularização óssea, diferenciação dos condrócitos, osteoblastos, células endoteliais e osteoclastos e na formação do tecido medular.

$\mathrm{Na}$ análise utilizando o western blotting, observou-se que a expressão da proteína VEGF apresentou diferença estatisticamente significativa entre o grupo com uma e sem LBP em todos os períodos. No Grupo Exp II houve uma tendência para maior expressão da proteína VEGF e isto nos leva a crer que nos outros períodos alguns fatores podem ter sido compensados por outros mediadores químicos ou células, pois se a $\mathrm{PGE}_{2}$ aumenta a expressão de VEGF, espera-se que nos animais tratados com laser o VEGF esteja mais expresso em todos os períodos, e foi o que foi observado na presente pesquisa. No período final de observação (10 dias) houve diferença estatisticamente significativa para o Grupo Exp I e porém não para o Exp II quando comparado com o controle. Sugere-se que neste período no grupo Exp II, o organismo consiga frear a destruição tecidual, bloqueando o processo inflamatório, sugerindo um quadro de tendência a normalidade.

Na tentativa de promover maior conforto ao paciente, as ciências da saúde vêm se preocupando constantemente com o desenvolvimento de mecanismos e técnicas capazes de minimizar os sinais clássicos da inflamação, como dor e edema. O efeito da laserterapia tem sido um assunto vastamente investigado nos últimos anos e é de alto interesse na área da Odontologia. Desta forma, o presente estudo avaliou a influência do LBP sobre a vascularização, em ratos, tanto histologicamente 
quanto em relação à expressão do gen VEGF. A análise histológica deste trabalho confirma achados prévios (PINHEIRO et al., 2003; PINHEIRO; GERBI 2006; KHADRA; KASEM et al., 2004; KHADRA; RONALD et al., 2004) mostrando que o LBP pode influenciar positivamente a reparação óssea.

Por meio da análise dos resultados do presente estudo, pôde-se observar que a laserterapia afetou o padrão de expressão para o gene VEGF. Portanto, a irradiação com o LBP teve importância durante a proliferação vascular e levou a uma forte resposta osteogênica, mas o seu papel é mais importante durante o início do processo. 



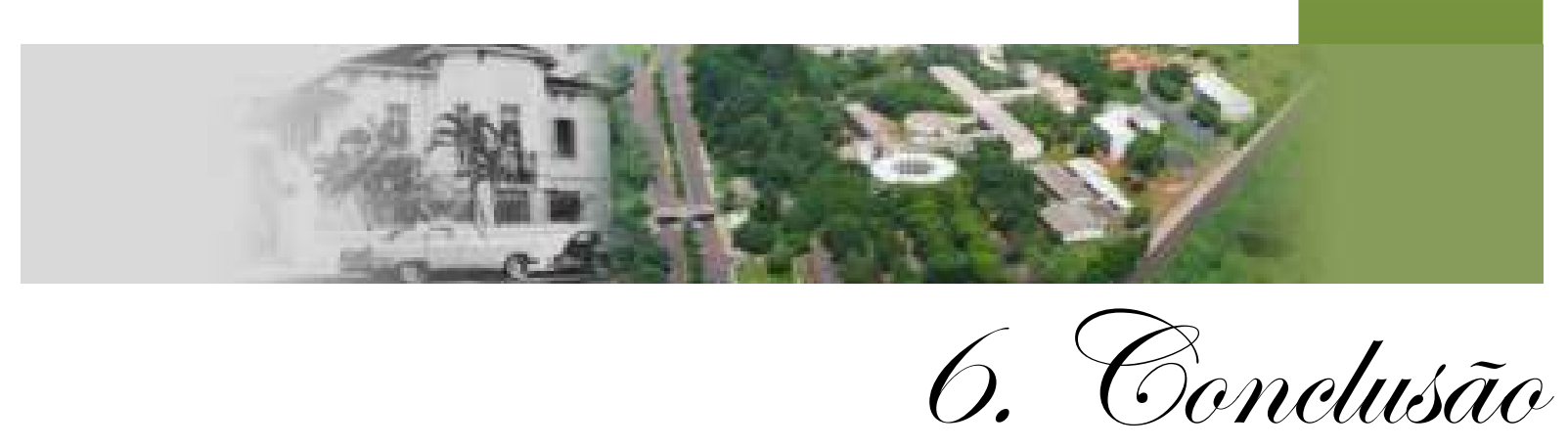





\section{CONCLUSÃO}

Respeitadas as características do presente estudo, a análise conjunta dos resultados obtidos neste trabalho, com a utilização de diferentes técnicas, permitiu sugerir que:

1. Foi observado que um aumento do processo inflamatório nos grupos experimentais e, este aumento foi maior no Experimental II.

2. Histologicamente observou-se que o grupo que foi irradiado após a ERM mostrou uma aceleração do processo de reparo ósseo quando comparado ao grupo que só recebeu a ERM.

3. Quando se comparou o grupo que recebeu irradiação com o que não recebeu irradiações, após a ERM, observou-se que um aumento da expressñao gênica e protêica do VEGF. Da mesma forma quando comparou-se estes grupo ao Controle. 



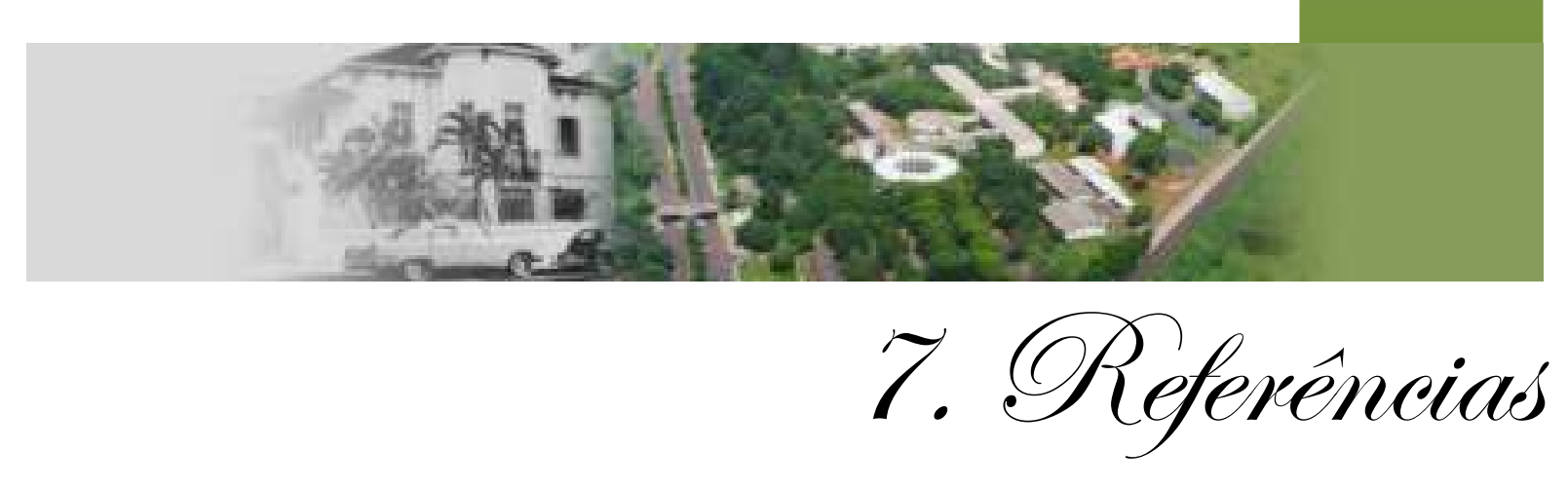





\section{REFERÊNCIAS ${ }^{1}$}

Aai-Aql ZS, Alagl AS, Graves DT, Gerstenfeld LC, Einhorn TA. Molecular Mechanisms Controlling Bone Formation during Fracture Healing and Distraction. J Dent Res. 2008 Feb; 87(2): 107-18.

Angeletti P, Pereira Md, Gomes Hc, Hino Ct, Ferreira Lm. Effect of low-level laser therapy (GaAlAs) on bone regeneration in midpalatal anterior suture after surgically assisted rapid maxillary expansion. Oral Surg Oral Med Oral Pathol Oral Radiol Endod. 2010 Mar; 109(3):e38-46.

Arana V, Bradaschia V. Biologia celular e tecidual para Odontologia: moléculas, células e tecidos. Rio de Janeiro: Elsevier; 2012. p.240-242.

Artese L, Rubini C, Ferrero G, Fioroni M, Santinelli A, Piattelli A. Vascular endothelial growth factor (VEGF) expression in healthy and inflamed human dental pulps. J Endod. 2002 Jan; 28(1):20-3.

Bhaskar SN. Histologia e Embriologia Oral de Orban. 10. ed. Artes Médicas; 1989. $501 \mathrm{p}$.

Booth V, Young S, Cruchley A, Taichman NS, Paleolog E. Vascular endothelial growth factor in human periodontal disease. J Periodontal Res. 1998 Nov; 33(8):4919.

Botero TM, Mantellini MG, Song W, Hanks CT, Nor JE. Effect of lipopolysaccharides on vascular endothelial growth factor expression in mouse pulp cells and macrophages. Eur J Oral Sci. 2003 Jun; 111(3):228-34.

Bradford MM. A rapid and sensitive method for the quantitation of microgram quantities of protein utilizing the principle of protein-dye binding. Anal Biochem. 1976 May $7 ;(72): 248-54$.

Brighton CT, Fisher JR, Jr., Levine SE, Corsetti JR, Reilly T, Landsman AS, et al.,The biochemical pathway mediating the proliferative response of bone cells to a mechanical stimulus. J Bone Joint Surg Am. 1996 Sep; 78(9):1337-47.

Brugnera Junior, A. et al. Atlas de laserterapia aplicada à clínica odontológica. São Paulo: Santos. 2003.

Brugnera, A.J.; Pinheiro, A.L.B. Lasers na Odontologia Moderna. 1. ed. São Paulo: Pancast. 1998.

\footnotetext{
${ }^{1}$ De acordo com o Estilo Vancouver
} 
Bustin, S.A. Absolute quantification of mRNA using real-time reverse transcription polymerase chain reaction assays. J Mol Endocrinol. 2000; 25(2):169-193.

Carlile, J. et al. Vascular endothelial growth factor (VEGF) expression in oral tissues: possible relevance to angiogenesis, tumor progression and field cancerisation. $\mathrm{J}$ Oral Pathol Med. 2001 Sep; 30(8): 449- 457.

Chain J, Jones MK, Tarnawski AS. Serum response factor is a critical requirement for VEGF signaling in endothelial cells and VEGF induced angiogenesis. The Faseb Journal. 2004 June;1-19.

Charnock-Jones DS, He Y, Smith SK. Angiogenesis and vascular endothelial growth factor (VEGF) in reproduction. In: . Fan TD, Kohn EC. The new angiotherapy. Totowa: Humana Press, 2002. Cap.8, p. 115-124.

Consolaro A. Reabsorções Dentárias nas Especialidades Clínicas. 2. ed. Dental Press; 2005. 615p.

Cowin SC. On mechanosensation in bone under microgravity. Bone. 1998 May; 22(5 Suppl):119S-25S.

Cowin SC. The significance of bone microstructure in mechanotransduction. J Biomech. 2007; 40 (Suppl 1):S105-S109.

Davidovitch Z. Tooth movement. Crit Rev Oral Biol Med. 1991;2(4):411-50. Review.

Ferrara N. Vascular endothelial growth factor. Eur J Cancer. 1996 Dec; $32 \mathrm{~A}(14): 2413-22$.

Ferrara N. VEGF: an update on biological and therapeutic aspects. Curr Opin Biotechnol. 2000 Dec; 11(6):617-24.

Ferrara N, Gerber HP, LeCouter J. The biology of VEGF and its receptors. Nat Med. 2003 Jun; 9(6):669-76.

Ferrara N. Vascular endothelial growth factor: basic science and clinical progress. Endocr Rev. 2004 Aug; 25(4):581-611.

Folkman J, Klagsbrun M. Angiogenic factors. Science. 1987 Jan; 235(4787):442-7.

Folkman J, Shing Y. Angiogenesis. J Biol Chem. 1992 Jun 5; 267(16):10931-4.

Gaengler P, Merte K. Effects of force application on periodontal blood circulation. A vital microscopic study in rats. J Periodontal Res. 1983 Jan;18(1):86-92.

Garant PR. Oral Cells and Tissues. Illinois: Quintessence Books; 2003.

Giordano V, Giordano M, Knackfuss IG. Fatores de crescimento e diferenciação ósseos. Efeitos sobre o processo de consolidação de fratura: presente e futuro. Rev Bras Med. 2000; 57(9):14-20. 
Giordano V, Giordano M, Knackfuss IG, Apfel MI, Gomes RD. Effect of tenoxicam on fracture healing in rat tibiae. Injury. 2003 Feb; 34(2):85-94.

Goede V, Schmidt T, Kimmina S, Kozian D, Augustin HG. Analysis of blood vessel maturation processes during cyclic ovarian angiogenesis. Lab Invest. 1998 Nov;78(11):1385-94.

Goodis $H$, Saeki K. Identification of bradykinin, substance $P$, and neurokinin $A$ in human dental pulp. J Endod. 1997 Apr; 23(4):201-4.

Gounis MJ, Spiga MG, Graham RM, Wilson A, Haliko S, Lieber BB, et al.,Angiogenesis is confined to the transient period of VEGF expression that follows adenoviral gene delivery to ischemic muscle. Gene Ther. 2005 May; 12(9):762-71.

Harada S, Nagy JA, Sullivan KA, Thomas KA, Endo N, Rodan GA, Rodan SB. Induction of vascular endothelial growth factor expression by prostaglandin E2 and E1 in osteoblasts. J Clin Invest. 1994 Jun;93(6):2490-6.

Harik SI, Hritz MA, LaManna JC. Hypoxia-induced brain angiogenesis in the adult rat. J Physiol. 1995 Jun; 485 (Pt 2):525-30.

Heller IJ, Nanda R. Effect of metabolic alteration of periodontal fibers on orthodontic tooth movement. An experimental study. Am J Orthod. 1979 Mar;75(3):239-58.

Hicklin DJ, Ellis LM. Role of the vascular endothelial growth factor pathway in tumor growth and angiogenesis. J Clin Oncol. 2005 Feb; 23(5):1011-27.

Hill PA. Bone remodelling. Br J Orthod. 1998 May; 25(2):101-7.

Holland R, Mazuqueli L, Souza V, Murata SS, Dezan Júnior E, Suzuki P. Influence of the type of vehicle and limit of obturation on apical and periapical tissue response in dogs teeth after root canal filling with mineral trioxide aggregate. J Endod 2007; 33:693-7.

Imhof BA, Dunon D. Basic mechanism of leukocyte migration. Horm Metab Res. 1997 Dec; 29(12):614-21.

In de Braekt MM, van Alphen FA, Kuijpers-Jagtman AM, Maltha JC. Effect of low level laser therapy on wound healing after palatal surgery in beagle dogs. Lasers Surg Med. 1991; 11(5):462-70.

Kaku M, Kohno S, Kawata T, Fujita I, Tokimasa C, Tsutsui K, et al.,Effects of vascular endothelial growth factor on osteoclast induction during tooth movement in mice. J Dent Res. 2001 Oct; 80(10):1880-3.

Kanzaki H, Chiba M, Arai K, Takahashi I, Haruyama N, Nishimura M, et al. Local RANKL gene transfer to the periodontal tissue accelerates orthodontic tooth movement. Gene Ther 2001 Apr;13(8):678-85.

Karu, T. Photobiology of low-power laser effects. Health Phys. 1989; 56 (5):691-704.

Katchburian E, Arana V. Tecido Ósseo. Histologia e Embriologia Oral. Texto - Atlas - Correlações Clínicas. Rio de Janeiro: Guanabara Koogan; 1999. p. 21-38. 
Katsube K, Bishop AT, Simari RD, Yla-Herttuala S, Friedrich PF. Vascular endothelial growth factor (VEGF) gene transfer enhances surgical revascularization of necrotic bone. J Orthop Res. 2005 Mar; 23(2):469-74.

Kawasaki K, Shimizu N. Effects of low-energy laser irradiation on bone remodeling during experimental tooth movement in rats. Lasers Surg Med. 2000; 26(3):282-9.

Khadra M, Kasem N, Haanaes HR, Ellingsen JE, Lyngstadaas SP. Enhancement of bone formation in rat calvarial bone defects using low-level laser therapy. Oral Surg Oral Med Oral Pathol Oral Radiol Endod 2004 Jun; 97(6): 693-700.

Khadra M, Ronold HJ, Lyngstadaas SP, Ellingsen JE, Haanaes HR. Low-level laser therapy stimulates bone-implant interaction: an experimental study in rabbits. Clin Oral Implants Res 2004 Jun;15(3):325-32.

Kohno S, Kaku M, Tsutsui K, Motokawa M, Ohtani J, Tenjo K, et al.,Expression of vascular endothelial growth factor and the effects on bone remodeling during experimental tooth movement. J Dent Res. 2003 Mar; 82(3):177-82.

Koransky ML, Robbins RC, Blau HM. VEGF gene delivery for treatment of ischemic cardiovascular disease. Trends Cardiovasc Med. 2002 Apr; 12(3):108-14.

Krishnan V, Davidovitch Z. Biological mechanisms of tooth movement. 1. Ed. WileyBlackwell; 2009. 241p.

Meikle MC. The tissue, cellular, and molecular regulation of orthodontic tooth movement: 100 years after Carl Sandstedt. Eur J Orthod. 2006 Jun; 28(3):221-40.

Mester E, Mester AF, Mester A. The biomedical effects of laser application. Lasers Surg Med. 1985; 5(1):31-9.

Nagasawa A, Kato K, Negisbi A. Bone regeneration effect of low level lasers including argon laser. Laser Therapy. 1991; 3:59-62.

Nissan J, Assif D, Gross MD, Yaffe A, Binderman I. Effect of low intensity laser irradiation on surgically created bony defects in rats. J Oral Rehabil. 2006 Aug; 33(8):619-924.

Nör JE, Christensen J, Mooney DJ, Polverini PJ. Vascular endothelial growth factor (VEGF)-mediated angiogenesis is associated with enhanced endothelial cell survival and induction of Bcl-2 expression. Am J Pathol. 1999 Feb;154(2):375-84.

Olsen BR, Reginato AM, Wang W. Bone development. Annu Rev Cell Dev Biol. 2000; 16:191-220.

Orikasa N, Shimakura M, Kusakari $H$. Effects of A]-Ga-As laser in bone histomorphometry. In: Yamamoto $\mathrm{H}$, Atsumi $\mathrm{K}$, Kusakari $\mathrm{H}$, editors. Lasers in dentistry. Amsterdam: Elsevier Science Publishers B.V. 1989; p.105-9.

Osawa Y, Shimizu N, Kariya G, Abiko Y. Low-power laser irradiation stimulates bone nodule formation at early stages of cell culture in rat calvarial cells. Bone. 1998 Apr; 22(4):347-54. 
Owan I, Burr DB, Turner CH, Qiu J, Tu Y, Onyia JE, et al. Mechanotransduction in bone: osteoblasts are more responsive to fluid forces than mechanical strain. Am J Physiol. 1997 Sep; 273(3 Pt 1):C810-C815.

Parfitt AM. Life history of osteocytes: relationship to bone age, bone remodeling, and bone fragility. J Musculoskelet Neuronal Interact. 2(6):499-500, Dec 2002a.

Parfitt AM. Size of bone in the aged endocortical resorption. J Bone Miner Res. 2002b Jul; 17(7):1306-8.

Parfitt AM. Misconceptions (2): turnover is always higher in cancellous than in cortical bone. Bone. 2002c Jun; 30(6):807-9.

Pe'er J, Shweiki D, Itin A, Hemo I, Gnessin H, Keshet E. Hypoxia-induced expression of vascular endothelial growth factor by retinal cells is a common factor in neovascularizing ocular diseases. Lab Invest. 1995 Jun; 72(6):638-45.

Pepper MS, Ferrara N, Orci L, Montesano R. Potent synergism between vascular endothelial growth factor and basic fibroblast growth factor in the induction of angiogenesis in vitro. Biochem Biophys Res Commun. 1992 Dec 15;189(2):824-31.

Pinheiro AL, Cavalcanti ET, Pinheiro TI, Alves MJ, Miranda ER, De Quevedo AS, et al. Low-level laser therapy is an important tool to treat disorders of the maxillofacial region. J Clin Laser Med Surg. 1998 Aug; 16(4):223-6.

Pinheiro AL, Gerbi ME. Photoengineering of bone repair processes. Photomed Laser Surg. Apr 2003; 24(2):169-78.

Pinheiro AL, Gerbi ME. Photoengineering of bone repair processes. Photomed Laser Surg. 2006 Apr; 24(2):169-78.

Plate KH, Breier G, Risau W. Molecular mechanisms of developmental and tumor angiogenesis. Brain Pathol. 1994 Jul;4(3):207-18.

Polverini PJ. The pathophysiology of angiogenesis. Crit Rev Oral Biol Med. 1995;6(3):230-47.

Polverini PJ. Angiogenesis in health and disease: insights into basic mechanisms and therapeutic opportunities. J Dent Educ. 2002 Aug; 66(8):962-75.

Proffit WR, Fields HW. Contemporary Orthodontics. St. Louis: Mosby; 2007.

Robling AG, Castillo AB, Turner $\mathrm{CH}$. Biomechanical and molecular regulation of bone remodeling. Annu Rev Biomed Eng. 2006; 8:455-98.

Sandy JR. Tooth eruption and orthodontic movement. Br Dent J. 1992 Feb 22;172(4):141-9. Review.

Saito S, Shimizu N. Stimulatory effects of low-power laser irradiation on bone regeneration in midpalatal suture during expansion in the rat. Am $\mathrm{J}$ Orthod Dentofacial Orthop. 1997 May; 111(5):525-32. 
Gonçalves CF. As casas de apoio no contexto das políticas públicas de saúde para a DST/HIV/Aids no Estado de São Paulo, no período de 1996 a 2003 [dissertação]. São Paulo: Universidade de São Paulo, Faculdade de Medicina; 2006.

Sawada M, Shimizu N. Stimulation of bone formation in the expanding mid-palatal suture by transforming growth factor-beta 1 in the rat. Eur J Orthod. $1996 \mathrm{Apr}$; 18(2):169-79.

Seifi, M., Shafeei, H.A., Daneshdoost, S., \& Mir, M. 2007. Effects of two types of lowlevel laser wave lengths (850 and $630 \mathrm{~nm}$ ) on the orthodontic tooth movements in rabbits. Lasers Med.Sci. 2007 Nov; 22, (4) 261-264.

Senger DR, Galli SJ, Dvorak AM, Perruzzi CA, Harvey VS, Dvorak HF. Tumor cells secrete a vascular permeability factor that promotes accumulation of ascites fluid. Science. 1983 Feb 25;219(4587):983-5.

Stashenko P, Teles R, D'Souza R. Periapical inflammatory responses and their modulation. Crit Rev Oral Biol Med. 1998; 9(4):498-521.

Takeda Y. Irradiation effect of low-energy laser on alveolar bone after tooth extraction: experimental study in rats. Int J Oral Maxillofac Surg. 1988; 17:388-91.

Trelles MA, Mayayo E. Bone fracture consolidates faster with low-power laser. Lasers Surg Med. 1987; 7(1):36-45.

Ueda Y, Shimizu N. Pulse irradiation of low-power laser stimulates bone nodule formation. J Oral Sci. 2001 Mar; 43(1):55-60.

Ueda Y, Shimizu N. Effects of pulse frequency of low-level laser therapy (LLLT) on bone nodule formation in rat calvarial cells. J Clin Laser Med Surg. 2003 Oct; 21(5):271-7.

Vandevska-Radunovic $\mathrm{V}$. Neural modulation of inflammatory reactions in dental tissues incident to orthodontic tooth movement. A review of the literature. Eur $\mathrm{J}$ Orthod. 1999 Jun;21(3):231-47.

Villars F, Bordenave L, Bareille R, Amedee J. Effect of human endothelial cells on human bone marrow stromal cell phenotype: role of VEGF? J Cell Biochem. 2000 Sep; 79(4):672-85.

Villars F, Guillotin B, Amedee T, Dutoya S, Bordenave L, Bareille R, et al.,Effect of HUVEC on human osteoprogenitor cell differentiation needs heterotypic gap junction communication. Am J Physiol Cell Physiol. 2002 Apr; 282(4):C775-C785.

Wlodarski KH. Properties and origin of osteoblasts. Clin Orthop Relat Res. 1990 Mar; (252):276-93.

Wolfson EM, Seltzer S. Reaction of rat connective tissue to some guttapercha formulations. J Endod 1975; 1:395-402.

Wong ME, Hollinger JO, Pinero GJ. Integrated processes responsible for soft tissue healing. Oral Surg Oral Med Oral Pathol Oral Radiol Endod. 1996 Nov;82(5):475-92. 
Yancopoulos GD, Davis S, Gale NW, Rudge JS, Wiegand SJ, Holash J. Vascularspecific growth factors and blood vessel formation. Nature. 2000 Sep; 407(6801):242-8.

Zengo AN, Pawluk RJ, Bassett CA. Stress-induced bioelectric potentials in the dentoalveolar complex. Am J Orthod. 1973 Jul;64(1):17-27. 



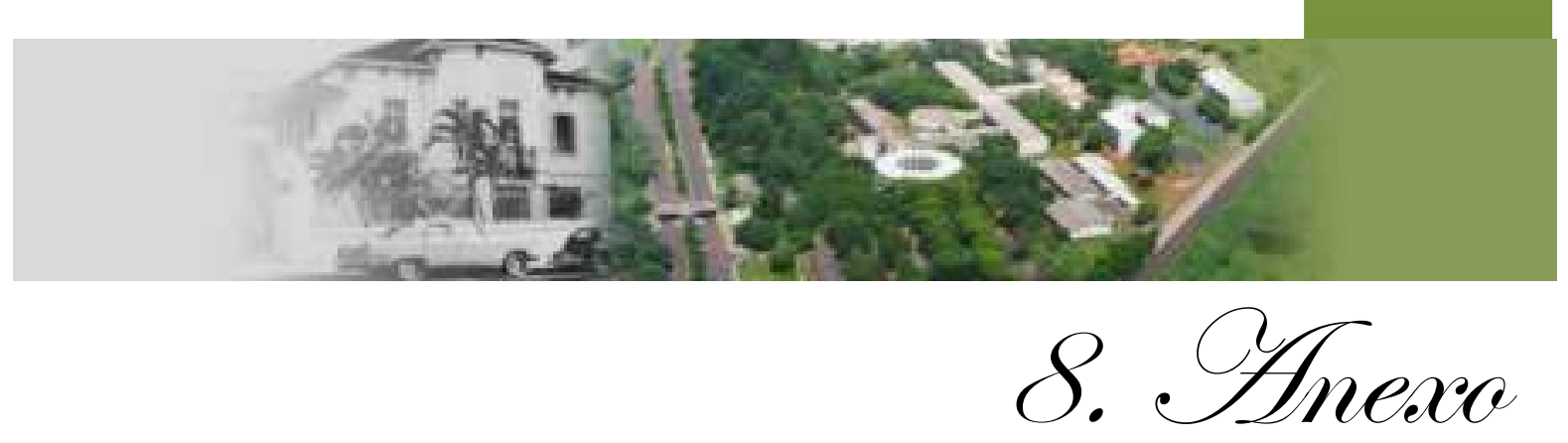





\title{
8. ANEXO
}

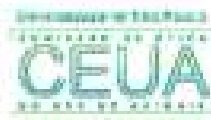

\author{
UNIVERSIDADE DE SĀO PAULO \\ Campus de Ribeirlio Preto
}

Comissilo de frice wo Uso de Amivaris

\section{E R T I F I C A D O}

\begin{abstract}
Certificamos que o trabalho (Protocolo $\pi^{2}$ 10.1.267.53.0), intilutado "Expressés dos Fatores de Crescimento Angiogednico (VEGF a FGF2) Liberados pela Polpa Dente, após a Expansáo da Maxila e Apticaçấ do Laser de Baixa Poténcia", de autoria de Maria Bernadete Sasso Stuani, poe estar de acordo com os Principios Éticos na Experimentaçăo Animal adotado pela Comissāo de Ética no Uso de Animais (CEUA) do Campus do Ribeirâo Preto - USP fol sprovado em reuniéo de CEUA de 071102010
\end{abstract}

This is to certify that the work (Protocol number 10.1.267.53.0), entitled 'Expressaso dos Fatores de Crescimento Angiogenico (VEGF e FGF2) Liberados pela Poipa Dental, spós a Expansäo da Maxila e Aplicaçăo do Laser de Baixa Potencia', by Marla Bernadete Sasso Stuani, is in accordance with the Etric Principies in Animal Experimantation adopted by Ethic Corimission for the Use of Animals (CEUA) of the Campus of Ribeirato Preto - USP, and was approwed in the meeting. October 07, 2010.

Ribeirso Prelo, B de oututro de 2010

Envor hetrobiun

Presidente da CEUA

Prota Dra. Christie Rsmos Andrade Lete Panissi

$4=f(t+0)$

Secrotaris de CEUA

Marid Angetica Depiro

$\sqrt{1}$

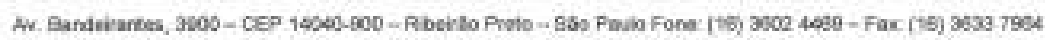

